UM Libraries Depositorv n.

110094909011 
BLACK ALUMNI OF THE UNIVERSITY OF MISSOURI-COLUMBIA:

FINANCIAL SUEPORT AS THE MIRROR OF ATTITUDES

A Dissertation presented to

the Faculty of the Graduate School

University of Missouri-Columbia

In Partial Fulfillment

of the Requirements for the Degree

Doctor of Philosophy

by

PAULA LAJEAN ROPER

Dr. Irvin W. Cockriel, Dissertation Supervisor

May 2001 
(C) copyright by Paula LaJean Roper 2001 All Rights Reserved 
The undersigned, appointed by the Dean of the Graduate School, have examined the dissertation entitled

\title{
BLACK ALUMNI OF THE UNIVERSITY OF MISSOURI-COLUMBIA: FINANCIAL SUPPORT AS THE MIRROR OF ATTITUDES
}

\begin{abstract}
presented by Paula LaJean Roper, a candidate for the degree of Doctor of Philosophy, and hereby certify that in their opinion it is worthy of acceptance.
\end{abstract}

\section{Dr. Irvin W. Cockrief (Advisor)}

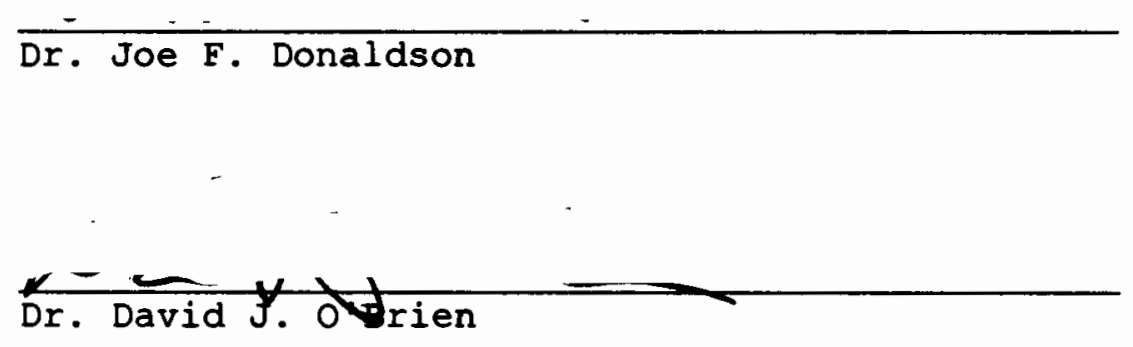

Dr. Feggy placier

Dr. Dougras Raber 


\section{Acknowledgements}

I am grateful to everyone and everything that assisted me in working on this study. First of all, my sincerest appreciation is extended to Dr. Irv Cockriel for his assistance, prodding, friendship, and never-failing faith. Dr. Joe Donaldson, Dr. Peggy Placier, Dr. David O'Brien, and Dr. Douglas Raber, the members of my dissertation committee, provided advice, assistance, time, and encouragement. I am profoundly grateful to each and every one of them.

My gratitude is extended to: Dr. Jeanette Hawkins Evans who allowed me to use the Black Alumni Survey; Dr. Carolyn Dorsey for her encouragement; Dr. Gary Fox for never letting me forget; Mr. Bob Almony for support; Dr. Pat Boyer for advice; Dr. John Hagar for assistance; Dr. Julie Caplow for her help; Ms. Clare Welch for her undying faith; Dr. Chris Lucas for a chance; Dr. Nick Adams for his kindness; Dr. Rosie Albritton for many things; $\mathrm{Mr}$. Mike Corlee, Ms. P.T. Martin, Mr. Mike Cook, Mr. Kent Edwards, Ms. Dawn Eisner, and Mr. Roger Knouff for computer-related help; Dr. Vicki Holtzapple for faith and friendship; Dr. Timothy Smith for his insights; Ms. Lorraine Caputo for all her help. My mother, Ola M. Roper, sister, Dorothy L. Roper, and dear friend, Georgia Grisby have helped me in so many ways that I cannot even 
fathom my debt to them. My husband Steve skolnick always encouraged me.

My teachers, colleagues, and friends have my deepest gratitude. I am eternally in the debt of those who went before me, and the power that guides the universe. 


\section{ABSTRACT}

This study focused on whether the attitudes of African American alumni toward the University of Missouri-Columbia are reflected in their donorship. At the time that the sample was drawn, slightly more than one percent of the alumni of the large, public, predominantly white institution was Black.

The Black Alumni Survey, an instrument developed by Dr. Jeannette Hawkins Evans, was used to assess alumni perceptions of the school's leadership, image, correspondence, alumni association, student experiences, and general impressions of fund raising techniques and purposes. ANOVA was chosen for the statistical procedure. No significant difference was found in the attitudes of donors and nondonors toward the school. Both groups seemed to share many basic perceptions and views of the university, possibly differing in the ways in which these ultimately were interpreted as determinants of action. Donors and nondonors seemed to perceive most aspects of the university's management, image, and leadership as positive. Their relationships and experiences associated with the school were also viewed as good.

Finding no difference in the attitudes of donors and nondonors was quite provocative and occasioned an extension of the analysis of Black donorship for the university. Alumni giving relevant to specific decades and schools or 
colleges within the university were assessed. When donorship was examined in terms of these categories interesting patterns emerged.

As a consequence of this research, it recommended that additional studies of alumni donorship be undertaken in order to try to determine more about this complex phenomenon. Additionally, Black alumni of the University of Missouri-Columbia should be consulted regarding marketing of the institution and development projects. 


\section{LIST OF TABLES}

Percentage Distribution of the 1,934 Population by Sex..... 60 Percentage Distribution of 335 Selected for Survey by Sex....61 Percentage Distribution of Sample by Sex \& Donor Status ..... 61 Percentage Distribution of Donors by Sex \& Geographic Location 62 Percentage Distribution of Nondonors by Sex \& Geographic

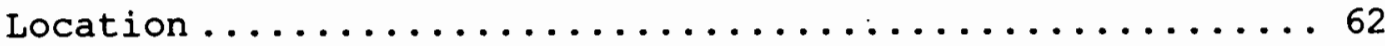

Percentage Distribution by MU Degree \& Donor Status ........63 Percentage Distribution by Highest Degree Held from Any

Institution \& Donor Status ................... 64 Percentage Distribution by Marital Status \& Donor Status ..... 65 Percentage Distribution by Age \& Donor Status ...........66 Percentage Distribution by Income \& Donor status ..........67 Donors and Nondonors, Males and Females, Question $15 \ldots \ldots 6$ Donors and Nondonors, Males and Females, Question $18 \ldots \ldots \ldots 9$

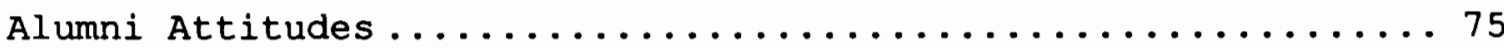

Reliability Summary for the Black Alumni Survey by Item ..... 80 Item Descriptive Statistics Summary for the Black Alumni

Donor Survey, by Item .................... 82

Descriptive Statistics for the Black Alumni Survey, by Donor

status ............................ 83

ANOVA results for the Black Alumni survey ............. 84

Donorship of Black and Non-Black Alumni, By Decades.......996 Donorship of Black \& Non-Black Alumni, By College or School... 98 Earnings by Highest Degree for Blacks \& Whites, by Gender... 100 


\section{LIST OF FIGURES}

FIGURE 1: Means for the black alumni survey, by donor status.. 84 
ACKNOWLEDGEMENTS $\ldots \ldots \ldots \ldots \ldots \ldots \ldots \ldots \ldots \ldots \ldots \ldots \ldots \ldots$

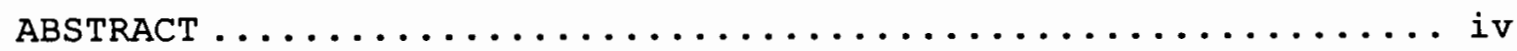

LIST OF TABLES $\ldots \ldots \ldots \ldots \ldots \ldots \ldots \ldots \ldots \ldots \ldots \ldots \ldots \ldots \ldots$

LIST OF FIGURES $\ldots \ldots \ldots \ldots \ldots \ldots \ldots \ldots \ldots \ldots \ldots \ldots \ldots \ldots \ldots \ldots$

TABLE OF CONTENTS ...............................

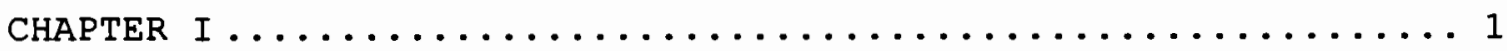

Introduction $\ldots \ldots \ldots \ldots \ldots \ldots \ldots \ldots \ldots \ldots \ldots \ldots \ldots$

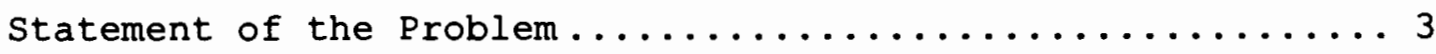

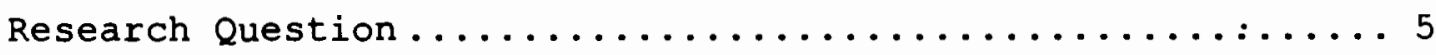

Definition of Terms $\ldots \ldots \ldots \ldots \ldots \ldots \ldots \ldots \ldots \ldots \ldots$

Importance of the study $\ldots \ldots \ldots \ldots \ldots \ldots \ldots \ldots \ldots \ldots \ldots$

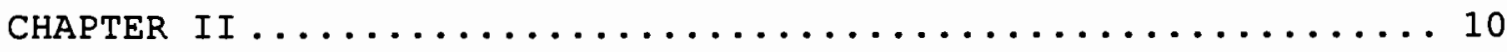

Review of the Literature ...................... 10

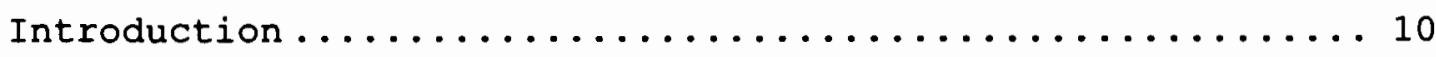

Historical Context........................ 20

Black Philanthropy and Higher Education............. 29

The Black Experience at Predominantly White

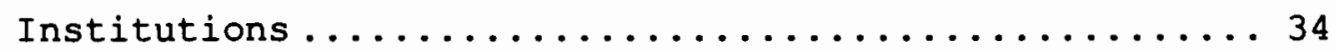

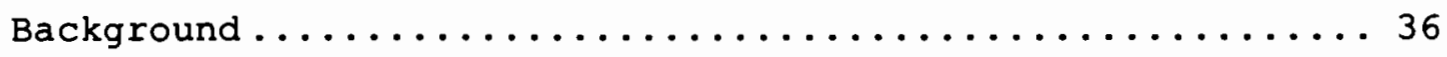

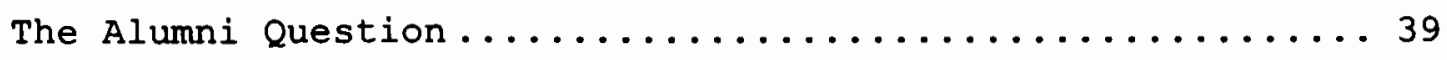

summary $\ldots \ldots \ldots \ldots \ldots \ldots \ldots \ldots \ldots \ldots \ldots \ldots \ldots \ldots \ldots \ldots$

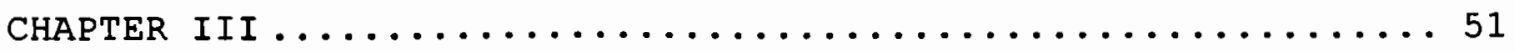


Design of the study $\ldots \ldots \ldots \ldots \ldots \ldots \ldots \ldots \ldots \ldots \ldots \ldots \ldots$

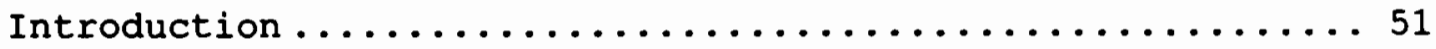

Research Question, Hypothesis, and Statistical

Analysis ............................. 51

subjects $\ldots \ldots \ldots \ldots \ldots \ldots \ldots \ldots \ldots \ldots \ldots \ldots \ldots \ldots \ldots \ldots \ldots \ldots$

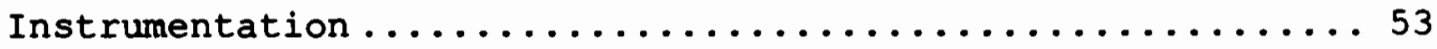

Data Collection .......................... 56

Demographic Data ........................... 57

Justification for the study $\ldots \ldots \ldots \ldots \ldots \ldots \ldots \ldots \ldots \ldots \ldots$

Limitations of the study ..................... 59

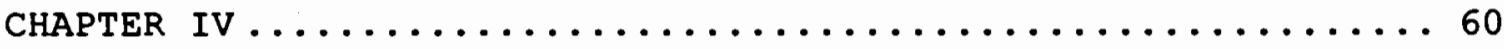

Presentation and Analysis of Findings ............. 60

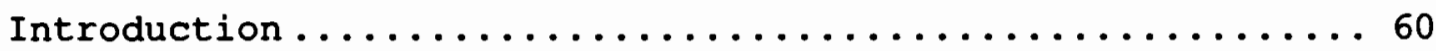

Results of Data for Alumni Attitudes ............. 70

Statistical Procedures ...................... 79

Summary $\ldots \ldots \ldots \ldots \ldots \ldots \ldots \ldots \ldots \ldots \ldots \ldots \ldots \ldots \ldots \ldots \ldots$

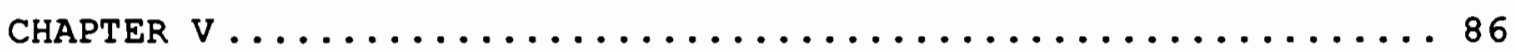

Summary and Conclusions ..................... 86

Introduction $\ldots \ldots \ldots \ldots \ldots \ldots \ldots \ldots \ldots \ldots \ldots \ldots \ldots$

Overview of Selected Related Research $\ldots \ldots \ldots \ldots \ldots \ldots \ldots$

Review of Black Alumni Survey Data................ 100

Discussion ............................... 107

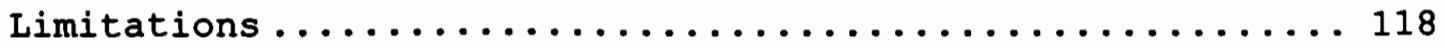

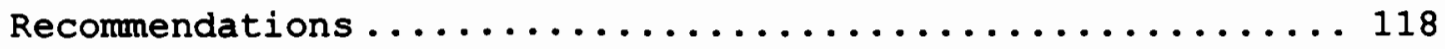


REFERENCES . . . . . . . . . . . . . . . . . . . . 119

APPENDIX A............................. 134

BLACK ALUMN SURVEY 135

APPENDIX B ................................. 139

Communications with Respondents ................. 139

Initial Contact Letter .................... 139

First Follow-up Letter..................... 140

Second Follow-up Letter..................... 141

Third Follow-up Letter.................... 142

APPENDIX $C \ldots \ldots \ldots \ldots \ldots \ldots \ldots \ldots \ldots \ldots \ldots \ldots \ldots \ldots \ldots \ldots \ldots \ldots$

LETTER OF PERMISSION 143

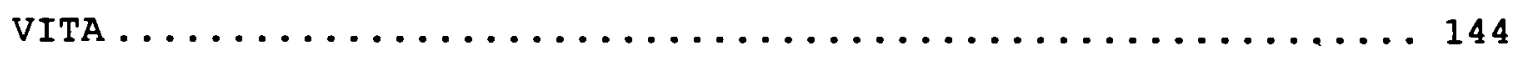


CHAPTER I

\section{Introduction}

During fiscal year 1998/99, the University of MissouriColumbia received $\$ 14,622,000$ in gifts from individual alumni (University of Missouri system, 1999). This figure represents over 428 of the gift money received that year. The significance of alumni money is, however, greater than the obvious benefits it bestows. Gifts from graduates reflect loyalty to the school, satisfaction with the education it provided, fond memories of experiences at the institution, confidence in its current. leadership, programs and policies (I.H. Allen, 1981; BurgessGetts, 1992, p. 4; J. H. Evans, 1986; L.T. Smith, 1987). Moreover, contributions from other possible benefactors, such as corporations, are linked to the degree of perceived alumni support, gauged on the basis of alumni donations (BurgessGetts, 1992, p. 4; J. H. Evans, 1986, p. 1; Shadoian, 1989, p. 1; Swanson, 1986, p. 2). Alumi donations assuredly are a critical source of revenue.

It is interesting to note that in 1995,148 of the nonBlack alumi donated to the University of Missouri-Columbia, while 78 of the Black alumni did so. This had been the general pattern since the start of that decade (Office of Development, 1995). In fiscal year 1998, 138 of all alumi donated and 108 of Black alumi did so (K. Ming, Oniversity of Missouri-Columbia, Office of Development, E-mail, February 4, 1999). By 2000, 
slightly over 398 of all alumni were contributors while a little over 208 of all Black alumni had become donors (K. Ming, University of Missouri-Columbia, Office of Development, E-mail, March 28, 2000). The Council for Aid to Education reported in 1998 that public research/doctoral institutions had an alumni solicitation effectiveness of $17.6 \%$.

Changing demographics are forecast to increase minority representation in the overall population over the ensuing decades. Blacks and certain other current minority populations have a significantly lower rate of participation in higher education than does the present numeric majority (Annual status Report, Minorities in Higher Education, 1998, pp. 13-15). An optimistic view of the future of higher education in America might hold that as minority populations become increasingly dominant numerically, their presence in academic institutions should grow proportionally. There is no guarantee that this will occur, however. Concomitantly, donations from alumni well may be affected by the impact of demographic change on academia. Further, if in communities with large African American populations, Blacks do not deign to attend college in significant numbers, revenue from tuition, alumni donations, and possibly even taxation could be affected. On the other hand, if Black attendance in academic institutions would increase in proportion to census representation, minimal alumni donations from this group could still negatively affect the operational capacity of schools. 
Academic institutions traditionally have not been a significant element in the pattern of Black philanthropy even though certain schools, such as Morehouse and Spelman, have benefited from a degree of change in African American giving in the past decade and a half (Carson, 1989; A. Evans, 1988; J. H. Evans, 1986; Winbush, 1996). The rate of Black alumni donorship at the University of Missouri has grown in recent years. The increase in Black alumni giving is attributed to the campaign for the new Black Culture Center (L. Scott; President, Black Alumni Organization, personal communication, March 28, 2000). Whether Black alumni become "habitual givers" can only be determined over time. Because of the importance of alumni donorship on several levels, this study was undertaken to research the attitudes of Black alumni toward the University of Missouri-Columbia in order to gain some understanding of an aspect of this phenomenon at a research one institution.

\section{Statement of the Problem}

One major concern of this study is the somewhat limited overall minority participation in higher education--particularly that of certain groups such as Blacks--while these groups are projected to become demographically dominant over the next few decades (Annual Status Report, Minorities in Higher Education, 1998, pp. 13-15; Wilson Justiz, 1987-1988, p. 9). This could threaten the established role and function that institutions of higher learning long have enjoyed in the society. 
Black alumni have a critical role in the relationship dynamic of institutions and the public. What alumni think of their school and how they express these views can not help but be influential in the larger community. For example, research has shown that Black alumni may be a critical factor in the recruitment of Black students (T. A. Harris, 1994; Rakestraw, 1985, p. 33). Furthermore, the financial assistance that Black alumni can provide their schools should not be ignored as it unfortunately has been all too often in the past (Carson, 1989, p. 23) .

My study examined the attitudes of Black alumni of the University of Missouri-Columbia toward the school and whether their donorship was reflected in their attitudes. The 1,934 Black alumni who attended the university through 1995 were the focus of this research.

With her permission, my study used a modified version of instrumentation developed by Jeanette Hawkins Evans, who in the mid-1980s examined the attitudes and giving patterns of alumni of six traditionally Black schools located in the South. My research, though, looked at the attitudes and financial support of Black alumni of a large public, predominantly white school. My study tried to determine what attitudes--based on student and alumni experiences, image of the institution, views of its leadership, and contact through mailings and telephone solicitation--Black graduates had of the University of MissouriColumbia and whether these perceptions were a factor in their 
willingness to donate. Moreover, my research compared the attitudes of donors and nondonors toward the school.

\section{Research Question}

The following research question was addressed: Is the donor status of the University of Missouri-Columbia's Black alumni affected by their attitudes toward their student and alumni experiences relevant to the institution?

\section{Definition of Terms}

These terms were defined for the purposes of this study: Alumni: Persons included on the university's alumni roster. Some of these individuals did not complete degrees at the University of Missouri-Columbia. Anyone who attended the school is listed on the alumni roster ( $K$. Ming, University of Missouri-Columbia, Office of Development, personal communication, March 29, 2000). Nevertheless very few of those listed on the alumni documents used for this study had not completed a degree at the university.

Black alumni: Individuals identified as Black on the MU alumi roster. University officials state that over the years, a number of individuals failed to fill in information specific to race on certain key documents such as applications (T. Coleman, Director, Alumni Relations, personal communication, March 29, 
2000; L. Scott, President, Black Alumni Organization, personal communication, March 27, 2000). Providing this type of data is up to the discretion of the applicant. Consequently, in all likelihood, some alumni, who would otherwise have been included in this study, were missed because university records do not identify them as Black.

Since some of the Black alumni of the university are from Africa, the Caribbean, South America, Europe, and other places, the term African American will be used only when appropriate. This study is limited to Blacks who attended the institution through 1995.

Donor: A person who has made a contribution to the University of Missouri-Columbia.

Nondonor: A person who has not made a contribution to the University of Missouri-Columbia.

Respondent: A person who completed and returned the Black Alumni Survey.

\section{Importance of the study}

The demographic changes facing the nation coupled with limited, although increasing minority participation in higher learning may threaten the role and scope of postsecondary education. A diminution in the importance of higher education could no doubt have many far-reaching, and perhaps not totally 
predictable, consequences for the various ethnic groups concerned, academic institutions, and the nation as a whole.

Even though 1988 marked the beginning of increased Black enrollment in institutions of higher learning after several years of decline (Wilson \& Justiz, 1987-1988, p. 14), schools should not become complacent. The college participation rate of African Americans as compared to whites is low (Annual status Report, Minorities in Higher Education, 1998, pp. 13-14). The participation rate of African Americans in higher education in 1996 was 35.98 (Annual Status Report, Minorities in Higher Education, p 1). Black male participation between 1995 and 1996 had increased from 34.48 to 35.28 which was a 68 increase over the rate a decade earlier (Annual Status Report, Minorities in Higher Education, pp. 13-14). Black female participation in higher education was at 36.68 which was a 78 increase over 1986 . Annual Status Report, Minorities in Higher Education (pp. 13-14) noted year-to-year fluctuations in these figures. There is no guarantee that the increased participation by Blacks in higher education, however tenuous, will continue unabated. Prudent efforts to secure greater African American participation in higher learning might benefit from the insight of research. Missouri's African American population was in excess of 118 in 1999 (Chronicle of Higher Education, p. 97). Nine percent of the students enrolled in Missouri's colleges and universities were Black in 1997 (Fact Book on Higher Education, 1997, 1997, p. 79). The University of Missouri had a Black enrollment of 68 
in the 2000 winter semester (K. Humphrey, Registrar's Office, personal communication, March 24, 2000). This figure, although low in comparison to the number of Black people in the state and the percentage enrolled in Missouri's academic institutions overall, represents a triumph for a university that as recently as 1993 had a total Black enrollment of less than 48 (Registrar's Office, 1995). The dramatic increase in Black students was the result of a concentrated recruitment and retention effort. This effort initially involved extensive visitations by university staff to high schools throughout the state. Particular attention was paid to schools in major cities, and fairly generous offers of financial assistance were made to potential students and extensive supportive measures were structured for those who matriculated ( $J$. Craig, Office of Vice-Provost for Minority Affairs and Eaculty Development, personal communication, April 3, 2000). That the University of Missouri-Columbia had a Black enrollment level of less than 48 for some time and only in recent years achieved higher percentages remains an issue of concern ("Minority Total Drops Again," 1999).

In the decades since complying with court-mandated desegregation, the university's roster of Black alumni included fewer than 1,200 persons by the end of the 1980s (K. Ming, University of Missouri-Columbia, Office of Development, E-mail, April 6, 2000). By 1995 this figure had risen to 1,934 (Office of Development, 1995). In 1998, the university had 2,739 living Black alumni. By December 1999, the number of living Black 
alumni was 2,924 (K. Ming, University of Missouri-Columbia, Office of Development, E-mail, March 28, 2000). Research specific to Black alumni attitudes should be helpful in fostering an understanding of the experiences of this group at the university over the years. Additionally, it might provide insight into ways to improve relations between the university and its Black alumni and students, and suggest means to make the university's organizational climate more responsive to the needs of this group. Moreover, it may help some alumi begin to examine their views of the university and whether or not their assistance might enable the institution to further its mission. Insights gained through this type of research have the possibility of enhancing communication between the university and its Black alumni, of determining if Black alumni donorship is influenced by their attitudes toward the school, and of identifying what characteristics distinguish the nondonor from the donor. Moreover, this research offered the possibility of helping to identify ways to improve the relations between a public institution and its Black alumni and students. The process and outcomes of this effort suggest other research might be conducted relevant to the school's Black alumni. 
CHAPTER II

\section{Review of the Literature}

\section{Introduction}

Over 4,000 separate institutions--many occupying vast tracts of urban, suburban, and rural land--are testaments to the nation's intense preoccupation with the multi-trillion-dollar industry that is American higher education (Fact Book on Higher Education, 1997, 1997, p. 377). In fact for several decades. higher education was a "growth industry." The Department of Education reported that 650 new schools opened during the 1970s, and 100 more had begun operating by the mid-1980s (Fact Book on Higher Education, 1989/1990, 1990, p. 133). The influence of higher education has become pervasive. For example, yearly since 1985, non-traditional students, i.e., persons over the age of 25 , once poorly represented on the collegiate level, have been $40 \%$ or higher of total enrollment and are projected to remain at those levels through 2007 (Digest of Education Statistics 1997, p. 184). For several years, however, economic conditions had a marked impact on some enterprises including schools. Consequently, new institutions no longer opened with quite the alacrity that could be noted several decades earlier. Enrollment in postsecondary institutions increased $30 \%$ between 1973 and 
1982. From 1986-1996, enrollment only grew by $14 \%$ (Digest of Education Statistics, 1998, 1998, p. 187).

Universities and colleges employ around 2,662,075 individuals (Digest of Education Statistics 1998, 1998, p. 252). The personnel associated with these institutions probably include virtually every position cataloged in the Dictionary of Occupational Titles (U.S. Department of Labor, Employment and Training Administration, U.S. Employment Service, 1991). Police officers, physicians, nurses, occupational therapists, dentists, laboratory technicians, librarians, computer programmers, janitors, cooks, groundskeepers, printers, journalists, sales clerks, attorneys, fund raisers, secretaries, human resources officers, administrators, and other occupations swell the employee rolls on many college and university campuses. However, as one would no doubt anticipate, a large segment, approximately 438, of those employed by these schools is involved with instruction (Digest of Education Statistics, 1998, 1998, p. 252).

Taken collectively, the financial concerns of institutions of higher education are considerable. Based on projections in the Fact Book on Higher Education, 1997, for 1996-1997, private institutions had revenues around $\$ 78$ billion; the total revenue of public institutions was in excess of $\$ 129$ billion (Fact Book on Higher Education, 1997, pp. 136-138). The sources of revenue for the two categories of institution varied considerably. For example, while public schools relied on tuition for only 18.48 of 
their income, tuition represented 41.98 of the revenue of private institutions (Fact Book on Higher Education, pp. 136-138). State governments provided more than 35.98 of the revenue available to public institutions (Fact Book on Higher Education, p. 136). Private schools, on the other hand, could only rely on state government for 2.18 of their income (Fact Book on Higher Education, p. 139). The federal government was more generous toward private than public schools, granting the former the equivalent of 14.58 of their total income while only favoring the latter with 11.38 of theirs (Fact Book on Higher Education, pp. 137-138). Local governments were more generous to public than to private institutions, providing public schools with 48 of their total revenue. Private institutions could rely on local government for less than 18 of their total income. At 23.48 for public schools, and 23.28 for private schools, both categories of institution derived revenue from sales and services at nearly equivalent rates. Private gifts, grants, and contracts provided private schools with more than 88 of their total revenue. Public institutions could depend on these two sources for about 48 of their income (Fact Book on Higher Education, pp. 136-138). Collectively, colleges and universities own land, buildings, and equipment valued in the trillions of dollars (Digest of Education Statistics, 1998,; Fact Book on Higher Education, 1997, p. 132). These same institutions also have fiscal liabilities that are considerable (Digest of Education Statistics, 1998; Fact Book on Higher Education, 1997, p. 140). 
with multiple millions of employees, students, and

graduates, billions of dollars in revenue, billions of dollars in expenditures, trillions of dollars in assets, and the many goods and services they provide, colleges and universities are critical factors in the overall economy of this nation and perhaps indispensable elements in some local economies.

Furthermore, institutions of higher education have assumed what seems to be a vital, perhaps even a critical role, in the overall society. Higher education today has several obvious functions: education, training, and research. of course education has implications far beyond mere formalized instruction. Some of the ways in which education acts upon the society hinges upon socio-political considerations, as examined in the works of Freire, Kozol, and others:

Sociologically, education is one of the most important means to reproduce the social structure of any society. Through education, as "a deliberate, systematic, and sustained effort to transmit or evoke knowledge, attitudes, values, and sensibilities," societies look for the means to reproduce their ways of life. However, the educational aspect is not only a mechanical transmission of knowledge and culture from one generation to another, but it is principally both a transformation and a transcending of that knowledge according to certain political and ideological points of view. In this sense, education may be used according to specific interests of some social classes. This implies that education is not only a pedagogic problem, but principally a political one. (Dupuy-Santiago, 1983, p. 1)

Higher education plays an important role in educating members of the various professions essential to the life of the nation. Moreover, universities and colleges inextricably are 
linked to research efforts in virtually all fields. The federal government alone awards millions of dollars a year to universities and colleges to fund research (Digest of Education Statistics 1998, p. 193). Numerous advances in science, medicine, education, mathematics, psychology, business, computer science, and other disciplines no doubt arise from research efforts on the nation's campuses.

In addition to their economic, educational, and research roles, institutions of higher learning seem to be called upon to play a major part in the moral life of the nation. In the 1960 s many of the efforts to reform the society and end the vietnam conflict were spearheaded on university campuses (Button Provenzo, 1989, p. 262). Numerous efforts to bring about the full participation of various groups in the society have some degree of connection with various university initiatives (Button \& Provenzo, pp. 269-290). Numerous books have been published attempting to grapple with the implications of multiculturalism for universities and colleges. The affirmative action controversy will no doubt continue to have a profound impact on campuses nationwide for some time to come. The lengths to which some university cultures have taken their role in changing the society may totter at times on the ludicrous--for example, the question of political correctness debated on many campuses in recent years. However, this does show a commitment to examine the problems of morality and ethics even to approaching the extremes of superciliousness. 
Colleges and universities serve as a training ground for athletes, sometimes riveting national attention on important competitions between opposing schools. Campus museums and libraries throughout the country locate, preserve, and display collections of often incalculable value. University theater companies, choral groups, and orchestras are a major factor in the cultural lives of many commities. Students from around the world flock to universities and colleges throughout the fifty states to prepare themselves in fields ranging from library science to nuclear physics.

Economically, socially, culturally, educationally, . politically, internationally, scientifically, perhaps even morally, higher education is a pivotal part of American life. The conditions of the society are not static though. Over the next few decades, the demographics of the United States are supposed to change significantly. Eventually, the nation's current minority populations are predicted to become the majority while the majority population will become the numeric minority. The implications of this shift have been widely discussed in many sectors. In March 1991, the House Subcomittee on Census and Population conducted a hearing to examine changing demographics. The transcript of that hearing, titled Changing U.S. Population and the Future Labor Force: Data Needs for the 21st Century, featured the testimony of experts in the field of demography. Dr. Clifford C. Clogg, Chair of the Committee on Population and Statistics of the Population Association of America, said: 
One challenge facing our society is to ensure equitable opportunities for these minority groups, partly because we can ill afford a condition where the productive capacity of Hispanics or non-Whites is not utilized. There are many other trends, demographic or population related, that have implications for our future labor force, as well as for the institutions that educate and train our workers. (p. 9)

Higher education has long been seen as a right of entry to the American dream. Even before slavery was eliminated from this nation, and during times when the prospects of employment for them commensurate with advanced degrees was virtually unthinkable, Blacks sought collegiate education and opened their own institutions to insure that there would be places where the talented and ambitious cotld study. The high school completion levels for Blacks have been rising steadily for many years. Despite this fact, an alarming trend was noted in the 1980s: a pronounced decline in Black participation in higher education (Annual Status Report, Minorities in Higher Education, 1993, p. 11). By the close of the decade, the trend reversed: annual increases in minority enrollment began to be noted. Nevertheless, in 1993, the gap between white and African American participation in higher education was significant, with 42.28 of Whites matriculating as opposed to 31.58 of Black high school graduates (Annual Status Report, Minorities in Higher Education, 1993, p. 9). In I996, 35.98 of African Americans were enrolled in college compared to 448 of white Americans. Completion rates of Black and white students were even more telling. In 1999, 17.48 of Whites held bachelor's degrees compared to 10.48 of 
Blacks (Statistical Abstract of the United States: 2000, 2000, p. 158). Moreover, only 4.68 of Blacks held advanced degrees contrasted with 8.58 of whites (Statistical Abstract of the United States: 2000, 2000, p. 158).

While it appears that minorities will become, over the next few decades, the real majority in terms of numeric representation in the population, limited participation by Blacks and some other minority groups in higher learning is a real concern (Gergen, 1998, p. 84; Wilson Justiz, 1987-1988, p.9). The National Center for Education statistics, in examining the data for 1994, noted that while enrollment by Asian-Americans had increased by 78 and Hispanics by 68, African American participation in higher education had only increased by 2.58 (Gose, 1996). Participation by Black women in higher education increased by $3.4 \%$; Black men on the other hand appeared even less enthusiastic about the academic experience with a growth of $1 \%$ (Gose, 1996). White enrollment was down by almost $2 \%$ from the previous reporting year, 1993. This was accounted for by changing demographics, however (Gose, 1996).

Because colleges and universities have long played such a key role in so many aspects of the nation's life--training professionals in every category, and serving as cultural, moral, political, and economic forces--their future no doubt has farreaching implications for the country as a whole.

The overall increase in minority participation in higher education should not necessarily be taken for granted. Even if 
demographic changes may be relied upon to continue the trend toward increasing minority representation in academia, the slight increase by Blacks in comparison with other groups is troubling. With the role higher education plays in the socioeconomic life of the nation, having a major group fail to avail itself--to the extent as have others--of that avenue to betterment may possibly have profound implications for the society and academia as well as for that group.

J. H. Evans noted in 1986 that there is remarkably little research specific to Black college or university alumni, particularly in relation to the donor patterns of the group. (1986, p. 9). In the years since the Evans study, there is still limited research related to this topic. Besides several dissertations, there have been articles in the Chronicle of Higher Education, the Journal of College Personnel, the Negro Educational Review, and other learned periodicals pertaining to Black alumni during this time. Nonetheless, articles on Black alumni donors remain relatively few and actual research on the subject rare. This is especially disturbing in view of the crucial problem facing schools, minority groups, and the nation in the dawning years of the new millennium (Allen \& Jewell, 1995; Wilson \& Justiz, 1987-1988, p. 9).

Education has been seen as an essential component of advancement since the beginnings of this nation (American Association of State Colleges and Universities, 1988, p. 3). If this belief has any validity, then minority groups, the society, 
and schools should seek ways to resolve the dilemma of rising minority birth rates coupled with somewhat limited participation by certain of these groups in higher education.

Overall, the focus of the literature review for this study sought to place the question of alumi donorship within a historical and societal context. The first portion of this literature review established a historical context for the study, examining Black education in merica. The question of philanthropy in relation to Black alumi ras the focus of the second portion of the revien. The third section concerned the problems of Black students at majority institutions. The fourth section looked at the background for the research. Finally, the literature review examined research specific to the topic of Black alumni and their role in higher education institutions. 


\section{Historical Context}

Education has been viewed for centuries as the "keystone to progress" in this nation (American Association of State Universities and Colleges, 1988, p. 3). Yet implicit in the American system of slavery, that "peculiar institution" that survived on those shores for more than two centuries, were traditions apparently antithetical to that "keystone" (L. Bennett, 1962, p. 70). The Cotton Curtain was the label Lerone Bennett (1962, pp. 70-95) gave the complex of traditions, laws, practices, and attitudes intended to regulate the behavior and interactions of Blacks and others during the period of American slavery. Bennett was not attempting to describe a diaphanous, decorous creation in using the term Cotton Curtain. Rather he referred to a system that was for Blacks as oppressive, totalitarian, and insular as that of the Soviet Union in the days when it most closely approximated the "Evil Empire." A member of the Virginia House of Delegates, referring to the practices of slaveholders, said in 1832, "We have as far as possible closed every avenue by which light may enter their minds. If we could extinguish their capacity to see the light our work would be completed" (Webber, 1978, p. 27).

Lunsford Lane, a former slave, remembered his period of servitude in haunting terms: "Indeed all things now made me feel - . that I was a slave. Deep was this feeling, and it preyed upon my heart like a never dying worm" (Webber, 1978, p. 24). Based on the plaintive musings of Lane and other former slaves, 
the Cotton Curtain must have been what the Virginia delegate had wished, nearly impenetrable by light. In fact, the cotton Curtain must have been created of a fabric so dense--if the testimony that has come down to us from those it once enclosed is to be credited--as practically to cut off the air.

If one may term the complex of law, tradition, practice, and attitude woven about the institution of slavery as the cotton Curtain, then the problem of education might be viewed as not just a thread but as a major portion of the pattern. Education is not just the formal process of schooling:

Schools do not and cannot monopolize education. From. the moment children are born, they begin their process of becoming educated--from mom, dad, brother, sister, and other members of the family; later from friends, neighbors, and the mass media. (Cortes, 1976, p. 10)

Formal education or schooling or even fust the process of learning to read was considered so inextricably related to the improvement of the indiviaual that both were forbidien to those holding the status of slave in virtually every slave state (Button \&rovenzo, 1989, p. 146). Even in the North, Blacks generally were unwelcome, and discouraged from pursuing formal education (Button Provenzo, p. 146).

Despite this history, or," perhaps even in part due to it, Blacks have long believed in the effleacy of education for: individual growth and improvement (American Association of State Colleges and Universities, 1988, p. 3). Nevertheless, the effort of Blacks to receive forwal instruction in this period was fraught with difficulty:- 
At an early phase in the development of slavery, Benjamin Franklin, Abbe Gregoire of Paris and other worthies took issue with those who regarded Blacks as innately inferior (Woodson, 1968, p. 69). Anthony Benezet, who in the latter decades of the eighteenth century taught students of both races, said that he found among Blacks the same range of abilities and talents that he did among a like number of Whites (Woodson, p. 69). Benjamin Banneker and Phyllis Wheatley were two early examples of American Blacks whose intellectual achievements brought them a degree of public notice (L. Bennett, 1962, p. 63).

Quakers enlisted very early in the cause to secure educational opportunities for Blacks. From at least the 1680 s, Quaker educational programs for Blacks can be documented (Ploski \& Williams, 1989, p. 732). Benjamin Banneker was educated in Maryland (L. Bennett, 1962, p. 66). In its early days, that state had been somewhat interested in elevating the status of Blacks. By 1800, however, the fear of Blacks was increasing. Gabriel Prosser of Virginia led his revolt that year (Button \& Provenzo, 1989, p. 146). The Haitian revolution, an uprising that fueled the nightmares of slaveholders, was nine years old. Until that time, Black children were taught in the so-called pauper schools in the State of Virginia (Woodson, 1968, pp. 112113). After Prosser's insurrection that avenue was closed, and Blacks desiring instruction had to seek private sources. North Carolina, from the late eighteenth through the early nineteenth century, allowed Blacks to be taught rudimentary 
skills such as reading and writing (Woodson, 1968, p. 113). By the third decade of the nineteenth century, there was a movement underway in that state to insure that all Blacks could read at least the Scriptures. Reactionaries quickly ended the effort. John Chavis, born a freeman in Oxford, Granville County, North Carolina around 1763, was educated at Princeton (AbdulKhabir, 1988, p. 16). In 1801, he went to Virginia and began preaching to Blacks. In 1831, a law prohibiting preaching by Blacks, free or otherwise, brought this phase of his life to a close (Woodson, 1968, p. 117). John Chavis then became an educator. Rather than Blacks, however, Chavis taught whites. . Several of his students went on to become prominent men (Woodson, p. 117).

Both Kentucky and Tennessee, before the views of slaveholders began to harden in the early nineteenth century, believed that the eventual manumission of Blacks was inevitable. A degree of instruction was encouraged in these states to prepare Blacks for this future. Private schools educated Blacks who could afford such an option. Some Black groups in these states established their own schools (Woodson, 1968, pp. 118-121).

By the early nineteenth century, generally, the Middle and Southern states ended their efforts to help educate Blacks. "Coloreds" and Whites attended schools together in New Orleans during this period, nonetheless. These institutions, though, were private. The child's family had to pay for his education (Woodson, 1968, pp. 128-129). 
In Charleston, South Carolina, with other possibilities closed to them, Blacks, during the period, opened their own selfsupporting schools. This experiment was rather successful. Many of the skilled craftsmen and merchants of the town were educated in these academies (Woodson, 1968, p. 129).

The District of Columbia had one of the most progressive Black populations and several good schools. The Snow Riot was an attempt to drive these progressive Blacks out of the community. While the riot succeeded initially, within a few years, relentless educators were once more operating Black academies (Woodson, 1968, pp. 130-137). Blacks in Baltimore followed those of the District of Columbia in founding their own private schools (Woodson, pp. 138-142). In Philadelphia and New York, Blacks relied upon schools opened for them by benevolent societies. By 1812 three "Colored" schools had been opened by Blacks in New York (Woodson, pp. 147-149).

Boston:s Black population opened a school after the American Revolution and maintained it for many years (Woodson, 1968; p. 149). In some New England communities, the public schools allowed Black children to attend. As a consequence, schools founded by Blacks frequently floundered since parents were not anxious to support two systems (Woodson, p. 149). In 1831, Mississippi made all Black freemen leave its borders (Woodson, 1968, pp. 164-165). Since it was illegal to provide formal education for slaves, the question of Black schooling within that state became moot. 
The fear of Black literacy had reached such extremes by the 1830 s that Blacks were forbidden even to set type in printing shops in various Southern states. Kentucky and Maryland never passed laws forbidding the instruction of any person. However, the force of public sentiment acted as effectively as legislation in these states to hamper the education of Blacks (Woodson, 1968, p. 169). Even in the Deep South, however, after prohibiting legislation was enacted, some Black schools remained open and unmolested. A few secret schools were kept to educate slaves (Woodson, pp. 215-217). Arguing that a literate slave would be far more valuable, some slaveholders were not only advocates of the education of Blacks but actually saw to it that their servants received instruction (Woodson, pp. 214-215).

In Connecticut during the 1830s, Prudence Crandall, a Quaker educator, opened a boarding school for young ladies. Sarah Harris, a Black girl, was eventually admitted. Some White parents demanded that Sarah be expelled. Prudence refused. All the White students were withdrawn. Prudence's advertisements for "Colored" students filled her academy. Miss Crandall and her charges did not have any easy time of it, though. Local stores refused their trade. The authorities frowned on crandall and the youngsters. Harassment of various types plagued the institution. Finally, legislation was enacted, declaring the experiment illegal. Prudence was jailed and later tried. On July 22, 1834, Prudence's attorney managed to get the case closed. The law that had prompted the legal proceedings was declared unconstitutional. 
Unrelenting attacks on the school continued, however; Prudence eventually closed her school (Woodson, 1968, pp. 172-175).

New Haven refused a Black manual arts college permission to operate during this period. Moreover, Noyes Academy in Canaan, New Hampshire was destroyed by irate citizens after the decision was made to open enrollment to Black students (Woodson, 1968, p. 176). In Northern cities, settlements of free Blacks usually included a school as well as a church. Such a settlement became the site of Wilberforce University in 1856. Schools founded by Blacks were frequently destroyed by mysterious fires though (Woodson, 1968, p. 11). Quaker settlements were viewed as meccas for Black education, and many Blacks went to these sites for instruction. Blacks who sought refuge in Canada also founded schools there (Woodson, p. 251). The widespread belief that prejudice against Blacks would diminish if the group were educated led to constant and ongoing efforts toward that end. There was, hewever, also a strong movement to repatriate Blacks to Africa. In support of this effort, several schools and colleges were opened in Liberia before 1851 (Woodson, p. 251). Myrtilla Miner, a New Yorker, was another young white woman who, like Prudence Crandall, sought to educate Blacks and endured persecution for her troubles. The Quakers and no less a notable than Harriet Beecher Stowe supported Myrtilla's work. Miss Miner established a school for young Black girls in washington, D.C. Harangues denouncing the institution appeared in newspapers of the day. Finally, in 1860 the school was torched. Before much 
damage could be done though, the fire was extinguished. Myrtilla operated her institution during the winter months; her summers were spent going about the country soliciting funds for the school. In 1866, Miss Minor died without realizing her dream of transforming the school into a teachers' academy (Woodson, 1968, pp. 266-268) .

Avery College was established in Allegheny City, Pennsylvania in 1849. In 1856 Lincoln University was incorporated in the same state. These institutions attest to an interest in providing Blacks with higher education from very early times. Additionally, oberlin, founded in ohio in 1833, and Berea, founded in Kentucky in 1869, had admission policies permitting the matriculation of Blacks from their inceptions (Abdul-Khabir, 1988, pp. 17-18). Some historians have noted that the Black experience at Oberlin may have been far from idyllic (Abdul-Khabir, p. 17). Nevertheless, while the Oberlin, Ohio experiment continued unmolested, by legislative decree the state of Kentucky in 1906 ended integrated education in its borders, closing Berea to Black students (Abdul-Khabir, p. 18).

By the 1860s, a number of Black colleges had been founded (Button \& Provenzo, 1989, p. 272). In the beginning, most of these institutions were colleges in name only, however, and in reality offered "secondary school instruction" (Button \& Provenzo, p. 272). Howard University was one of the few Black institutions of higher education to offer in actuality a college curriculum from its earliest days (Button \& Provenzo, p. 278). 
In 1849, the Supreme Court handed down a decision in the case of Roberts $v$. Boston, establishing the concept of segregated schools (Button \& Provenzo, 1989, p. 272). The Court's 1896 ruling in Plessy v. Ferguson sanctioned the segregation of accommodations along racial lines despite the fact that the Fourteenth Amendment had seemed, explicitly, to forbid such practices (Button \& Provenzo, p. 278). Cummings v. Richmond County, heard by the Court in 1899, unambiguously extended the concept of separate but equal to the educational system (Button \& Provenzo, p. 278).

Beginning in the 1930 s, organizations such as the NAACP fought segregation in the nation's courts (Button \& Provenzo, 1989, p. 278). Institutions of higher education, particularly graduate and professional schools, were seen as especially appropriate targets for this form of litigation (Button \& Provenzo, p. 279). The University of Missouri, founded in 1839, was party over. the years to some particularly notorious efforts to maintain its status as a segregated institution colson \& Olson, 1988, pp. 82-83.). By the early 1950s, a ruling by Judge Sam Blair, on a suit brought by the NAACP to integrate the institution, ended with the university's acceptance in theory of open admission to all qualified Missourians (Olson \& Olson, p. 84). Only after the Supreme Court's landmark 1954 decision in Brown $v$. Topeka did the university actually begin to have many Black admissions. The Office of Development reported that the 
first Black graduated from Missouri University in 1951 (D. Mayuiers, personal communication, April 10, 1996).

\section{Black Philanthropy and Higher Education}

Approximately 105 historically/predominantly Black

institutions of higher learning exist in this country (Digest of Education Statistics, 1998, 1998, p. 247). Historically Black colleges and universities (HBCU) have played a major role in the Black community in this nation. These institutions have, for example, educated individuals who have provided crucial services to their communities. Meharry, Howard, and Morehouse were dominant in the education of Black physicians practicing in the United States at one time (Moskowitz, 1994, p. 69). Furthermore, most Black leaders have been products of traditionally Black colleges (A. Evans, 1988, p. 15). Judith Waldrop in a 1990 article in American Demographics noted that a significant percentage of the so-called Black elite were products of institutions supported by the United Negro College Fund. Even today, these schools still produce a substantial number of the country's Black college graduates and members of the learned professions (Annual Status Report, Minorities in Higher Education, 1997, p. 84; Clinton, 1998). Where other institutions have been very selective, usually, in terms of admissions, Black schools have worked with students to help them develop the skills required to compete successfully in the academy and in life (A. Evans, p. 15). In all likelihood, a significant portion of 
Blacks will continue to seek the extra attention given students that is typical of traditionally Black colleges and universities. These schools provide employment for many scholars and administrators (A. Evans, p. 15). With the resurgence of racism that has been noted in the country, particularly on college and university campuses, traditionally Black colleges and universities may be viewed as a sort of refuge by some (R. Taylor, 1996, p. 10). Certainly, these schools are important historically, continue to serve as an invaluable resource for African Americans and the nation as a whole, and should be expected to fulfill these roles for some time to come.

Nevertheless, the Black alumni of these institutions have been notoriously stingy with their donations (A. Evans, 1988, p. 15; J. H. Evans, 1986; Joiner, 1998). Organizations which provide gifts, grants and other monies to institutions of higher education use alumni contributions as an indicator of the overall support from that sector. Critically they make that a determining factor in their own giving (Burgess-Getts, 1992, p. 4; J. H. Evans, 1986, p. 1; Shadoian, 1989, p. 1; Swanson, 1986, p. 2). Consequently, failure of alumni support is a key element in the fiscal crisis confronting many historically Black schools. Until recently, Blacks have been regarded, according to popular wisdom, as poor prospects for charitable giving (Carson, 1989, p. 23; Fletcher, 1997, p. A01; Nicklin, 1994, p. A29). So entrenched was this belief that very little solicitation was ever undertaken in the Black comminity (Carson, p. 23). Of course, 
Blacks did not usually donate to charities since they were asked seldom to do so (Carson, p. 23; Fletcher, p. A01). Carson (p. 23) quoted a Wall Street Journal article that seemed to epitomize the views of the fund-raising community in this regard: 'The thinking of the middle-class Black seems to be that as long as the federal government, corporations and philanthropies underwrite Black institutions, they are absolved of responsibility.' Carson felt that this statement misrepresented Blacks and failed to take into account the support this group provided so many American institutions in a variety of ways (Carson, p. 23).

Carson believed that Blacks have always been immersed in charitable activities, seeing the self-help of the community as a form of philanthropy (Carson, 1989; p. 24). The Black church was often the focal point of the mutual aid societies established by free Blacks beginning as early as the eighteenth century (Carson, p. 24).

Furthermore, Black philanthropy has long expressed itself as a public power (Carson, 1989, p. 24). The Underground Railroad was seen as one example of this form of public power use of philanthropy:

The underground rallroad sponsored national and international fund-raising campaigns, used volunteers as railroad "conductors;" uséd the homes of supporters as railroad "stations," and lastly, provided escaping slaves with foodd, elbthting, shelter, new identity papers, and money. Many of the black mutual aid societies and fraternal organizations were actively involved in supporting all aspects of the railroad's operation. (Carson, 1989, p. 24) 
The civil rights movement is a more contemporary example of Black public philanthropy (Carson, 1989, p. 26). Of course, the Black church has remained a focal point of Black giving.

The Joint Center for Political Studies has been contrasting the attitudes and giving patterns of Blacks and whites for several years. The center found that households with the same income level, whether minority or majority group, showed very similar giving patterns (Carson, 1989, p. 27). Moreover, the reasons expressed by members of the two groups for donating or not donating to charity were comparable" (Carson, p. 27).

Furthermore, while in general Blacks are thought of as impoverished, there is actually a great deal of money in the community (Reynolds, 1992, p. 9A). For example, the total annual income of the group was found to be approximately $\$ 300$ billion in the early 1990s (Reynolds, p. 9A). A significant percentage of Black America's income was used for discretionary purchases (Reynolds, p. 9A). In fact, Blacks bought about 508 of all movie tickets, and spent around \$16 billion annually for "airline tickets, hotels, car rental, clothes, and baby sitters," primarily in conjunction with attendance at reunions and conventions (Reynolds, p. 9A). More than $\$ 100$ million was spent just by those attending the annual Congressional Black Caucus weekend in Washington, D.C. in 1992 (Reynolds, P. 9A). There are approximately 35,454,000 Black people, 12.98 of the population, residing in the United States. By 2050 African Americans should account for 14.78 of the population residing within the country 
(Statistical Abstract of the United States: 2000, 2000, p.16). The economic power of Black Americans has and continues to grow significantly ("The Black Middle Class," 1998, p. 8). "From 1990 to 1997, the African American populations' disposable income increased 548 , versus 418 for the entire United States population" (McLaughlin, 1999, p. 100-101). In fact, Blacks are predicted to increase substantially numerically in the coming years and to grow significantly in economic power. Middle class Blacks are increasing faster than most other groups within the population (R. L. Harris, 1999, p. 40).

In 1988, Bill and Camille Cosby donated $\$ 20$ million to Spelman College. This practically unprecedented philanthropic event underscored the possibilities of Black charitable activity. Certainly, few individuals, white or Black, can donate millions of dollars to any institution. Nevertheless, there are some Blacks with the financial capital to do so. Perhaps almost as importantly, Blacks with much less revenue can make significant donations to various enterprises.

A 1989 article in the Chronicle of Higher Education referred to what may be a reason the history of Black alumni support of traditionally Black schools was so dismal: "in the main, except for crisis, Black alumni were simply not asked by their alma maters for donations" (Leatherman, p. A31). Perhaps these schools may have felt that the donations should have come without the need for solicitation since their financial problems were frequently frighteningly apparent. Or it may have been 
reluctance even on the part of Black organizations to ask for money from what is considered to be, generally, a poor group. Perhaps many of these schools, fighting for their survival, with too few hands to do so many tasks, never organized ongoing efforts to spur alumni giving.

During his presidency, Roy Keith decided that Morehouse would mount an ongoing, systematic campaign to secure alumni support. His initial efforts met with success. "I knew we were sitting on great potential with all the enthusiasm our alumni have," said President Keith. "We just needed to structure something" (Leatherman, 1989, p. A31). Oliver Gleck, the Morehouse Development officer, stated in a phone interview that alumni giving to that institution was then, in 1996, at between 33\% and 368. Prior to the efforts undertaken in the late 1980s, only 158 to 218 of Morehouse's graduates contributed to the institution. Mr. Gleck believed that Morehouse alumni had a strong:

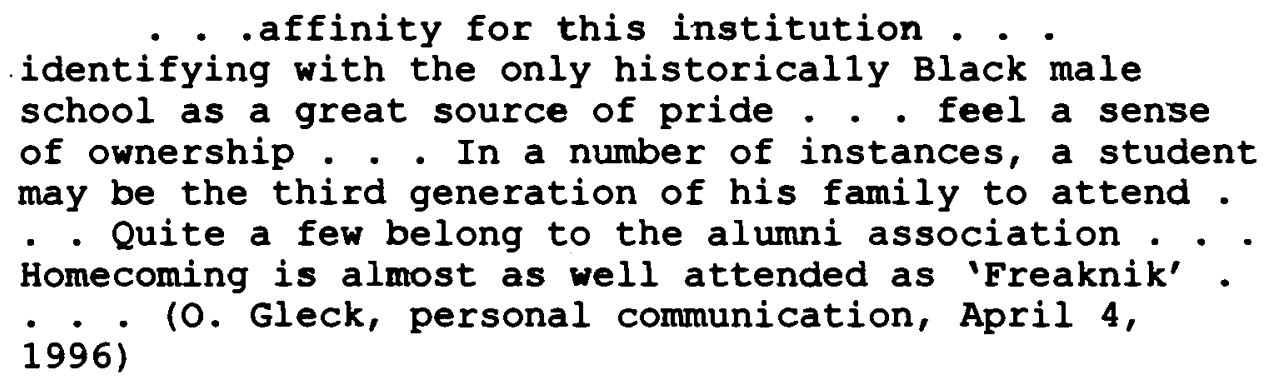

The Black Experience at Predominantly white Institutions

Today Black students are more likely to enroll at white institutions than at historically Black schools (W. R. Allen, 1987, pp. 28-44; Annual Status Report, Minorities in Higher 
Education, 1998, p. 90). Only 158 of African American students were enrolled in historically Black institutions in 1996 (Annual Status Report, Minorities in Higher Education, 1998, p. 21). In 1993-1994, fewer than 308 of the bachelor degrees awarded to Black students were granted by Black schools (Annual Status Report, Minorities in Higher Education, 1998, p. 96; Fact Book on Higher Education, 1997, 1997, p. 196). Black enrollment in all institutions of higher learning throughout the decade of the 1980s evidenced a notable drop from the high point reached in 1979-1980, though it had doubled between 1960-1980 (Arbeiter, 1987, pp. 14-19). The high dropout rates for African American students attending predominantly white colleges and universities account in part for this decrease (Harvey Williams, 1989, p. 328; "Retention Problems," 1999, p. 12). Since 1988, Black enrollment in higher education has increased. At one point, greater numbers of African American students opted to attend Black schools (Jenifer, 1991, p. A60). The lower cost of many such institutions, or a desire of Black students to seek more congenial environments may explain this. The experiences of Black students at traditionally Black schools are said to be very different from their experiences at predominantly white institutions (Baratz \& Ficklin, 1983; Wallace \& Bell, 1999, p. 308). Black students attending predominantly white schools supposedly fare poorly in comparison with their white counterparts in terms of persistence rates, academic achievement, and psychological and social adjustment (Bynum Thompson, 1983, 
pp. 55-76; Haworth, 1996, p. A33). Black collegians reportedly experience greater difficulty adjusting to what is seen as a socially alienating, culturally different, and academically demanding environment (W. R. Allen, 1987, p. 24). A number of predominantly white schools, including the University of Missouri-Columbia, have endeavored to correct this problem in recent years by establishing supportive functions and structures within their institutions for minority students ("Minority Total Drops Again," 1999; Townsend, 1994, pp. 85-89).

\section{Background}

J. H. Evans found that by any measure most historically Black colleges and universities were in dire circumstances (1986, p. 2). More than 408 of these institutions were operating under a deficit (Evans, p. 2). Many Black educational institutions were poorly funded, deeply in debt, and hanging onto continued fiscal viability by the proverbial thread (Evans, p. 15). Enrollment at these schools was also in decline at the point Dr. Evans' study was conducted (Evans, p. 2). The salary level of faculty at such schools was about 158 lower than that paid their colleagues at comparable, predominantly white institutions (Evans, p. 2).

Fiscal distress resulted in the closing or near closing of several Black schools over the years, including Bishop College of northeast Texas (J. H. Evans, 1986, p. 4). Even such notable institutions as Fisk, Meharry, Atlanta Oniversity, and Knoxville 
College have almost succumbed to economic problems at various times (J. H. Evans, p. 17). Several university presidents, deemed inept fundraisers by certain key interest groups, were pressured into resigning (J. H. Evans, p. 4).

An article in the Chronicle of Higher Education (Healy, 1996, p. A30-A31+) indicates that the prospects for Black public institutions, with millions in deficits and a 358 drop in applications as indices, were at least as dire as they had been in the previous decade. Despite the fund raising triumphs of Spelman, Morehouse, and a few other HBCU, finance is still a major concern for these schools generally. The Kresge Foundation started working with various Black schools to help them establish viable development programs (Lively, 1999, p. A45).

Since the founding of Pennsylvania's Cheyney State in 1837, fiscal problems have been burdens Black schools have borne as they strive to improve the lot of African Americans (A. Evans, 1988, p. 15). Observers have attributed the financial plight of these schools to several causes. Somewhat desultory funding by federal and state governments is deemed a major culprit (Devarics, 1999, p. 8; J. H. Evans, 1986, p. 1). Contributing to the problem as well is the failure of this category of institution, in the main, to receive more than comparatively negligible support from corporations and philanthropic organizations (J. H. Evans, p. 1; Lively, 1999, p. A45). The central, truly pivotal issue is seen, though, as the lack of support that historically Black institutions generally have 
received from their alumi (Burgess-Getts, 1992, p. 4; A. Evans, 1988, p. 15; J. H. Evans, 1986, p. 1; Leatherman, 1989, p. A31; Shadoian, 1989, p. 1; Swanson, 1986, p. 2).

Agencies and organizations that provide gifts, grants, and other monies to institutions of higher education use alumni contributions as an indicator of the overall support from that sector and, critically, make that a determining factor in their own giving (Burgess-Getts, 1992, p. 4; A. Evans, 1988, p. 15; J. H. Evans, 1986, p. 1; Shadoian, 1989, p. 1; Swangon, 1986, p. 2). Failure to obtain alumni support is a key element in the crisis facing many historically Black schools. If Black schools are going to exist above the subsistence level, perhaps even if they are to continue to exist at all, some means to garner the support of their alumni seems imperative (Burgess-Getts, p. 4; A. Evans, p. 15; J. H. Evans, p.1; Shadoian, p. 1; Swanson, p. 2).

Many Black college and university graduates today are alumni of predominantly white institutions. The traditional failure of African Americans to support academic institutions may even be compounded in the instance of predominantly white institutions by a sense of alienation from these schools by Black alumni (L. T. Smith, 1987; Schwitzer, Griffin, Ancis, and Thomas, 1999, p. 189).

In the years since the J. H. Evans study of Black alumni, historically Black and wite institutions have been trying to improve relations with their Black alumni and increase donations 
from this group. Some schools, notably. Spelman and Morehouse, have met with success.

The Council for Aid to Education found in 1998 that 24.28 of alumni of reporting institutions contributed to solicitations from these schools (Voluntary Support of Education, 1998). According to the University of Missouri-Columbia's Office of Development, 398 of all living University of Missouri-Columbia alumni are donors and 208 of all living Black alumi can be placed in that category (K. Ming, University of MissouriColumbia, Office of Development, E-mail, March 28, 2000). The president of the Black Alumni Organization attributes the phenomenal increase in Black donors to the campaign surrounding the new Black Culture Center on the campus (personal communication, March 28, 2000). From 1990-1995, around 78 of Black alumni and 148 of all alumni were donors (Office of Development, 1995). In 1998, approximately 138 of all alumni were donors and the rate for Black alumni had increased to 108 (K. Ming, University of Missouri-Columbia, Office of Development, E-mail, February 4, 19.99l. .

\section{The Alumi Question}

Some problems faced by African American students in both minority and majority institutions of higher learning may be improved by strong alumni participation (Dunbar, 1991, p. 17; Rawlins, 1991). Donnette Dunbar (1991, p. 17) saw AfricanAmerican participation in alumni associations as a way to 
"address the specific needs of Black graduates and students." Also, networking--with its potential to facilitate job searches and develop business and social contacts--is a bonus connected with this sort of activity that Dunbar encouraged Black alumni to consider (1991, p. 17).

Several institutions founded separate minority alumi organizations in their attempts to increase participation in alumni activities by these groups (Rakestraw, 1985, p. 32). This approach was successful in terms of gaining minority group interest and support (Rakestraw, p. 32). Minority alumni associations are seen as a powerful recruitment tool (T. A. Harris, 1994, pp. 5-11; Rakestraw, p. 33; L. Scott, President, Black Alumni Organization, personal communication, March 28, 2000). Some though have condemned minority alumni groups as segregationist (Rakestraw, p. 32). There was also the concern that these associations were insular, responding only to what they perceived as their own needs while ignoring other institutional problems (Rakestraw, p. 32). Further certain critics thought that separatist alumni associations diluted general institutional development efforts (Rakestraw, p. 34). Separate alumni associations were viewed by some as a means of initiating minority participation in alumni activities. Once participation was established, adrocates of this position insist, the necessity for separate associations would no longer exist (Rakestraw, p. 34). Brown University is one institution that used separate alumni associations to its advantage (Carter, 1988, 
p. 46). Brown's Third Forld Alumi Activities Program garnered the institution an eightfold increase in participation in alumni activities by "U.S. citizens of African; Hispanic, Asian, or Native American descent" (Carter, p. 46).

Ewers (1987, p. 569), T. A. Harris (1994), Morrison (Graf, 1990, p. 23) and Scott (President, Black Alumni Organization, personal communication, March 28, 2000) strongly advocated the use of Black alumni to help recruit Black students. An increase in the applications and inquiries from Black students has risen significantly when this approach is used (Ewers, p. 569; Scott, 2000). Further, Black alumni, according to Ewers and Scott, may serve as mentors and role models to help in the retention of the students that they have helped to recruit (Ewers, p. 570; scott, 2000)

In 1988, Louisiana State University (LSU) sponsored a reunion attended by more than 200 Black alumni. Many of the attendees had extrenely painful memories of their experiences at that institution (Wilkins Emanuel-Wallace, 1990, p. 39). The university professed a desire to improve the environment for Black students, and was willing to have former Black students share their experiences, hoping this information might help (Wilkins E Enanuel-Fallace!' off in a way that usu did not antieipate: After the gathering, some participants asked the LSO Alumi Assoclation how they might organize a Black chapter (Nilkins Emanuel-Wallace, p. 39). 
The potential power of alumi should not be ignored. In the early 1970s, for example, Black alumni of Florida A\&M with the assistance of Black leaders ended an attempt to merge their alma mater and Florida State University (Mercer, 1992, p. A25). The University of Missouri-Columbia's Black Alumni Organization has been used in efforts to recruit students in both Kansas City and St. Louis (Graf, 1990, p. 23). Furthermore, the organization holds orientation programs for new minority students each year during the fall semester. KC Morrison, Vice-Provost for Minority Affairs and Faculty Development through the early mid-1990s, believed that Black alumni programs were the best means to recruit Black students (Graf, p. 23). The Black Alumni Organization engages in fund-raising efforts. Part of the proceeds from the group's solicitations goes to fund grants for Black students. Additionally, the association provides resources for minority internships and job placement activities, and assists student organizations (Graf, p. 23).

The Black Alumni Organization continues these activities, initiated over a decade earlier, publishes a newsletter, boasts 352 members, and may begin a project that would enable alumni to "mentor" students (L. Scott, President, Black Alumi Organization, personal communication, March 28, 2000). In March 28, 2000, there were 2,924 living Black alumni (K. Ming, University of Missouri-Columbia, Office of Development, E-mail, March 28, 2000). Therefore, slightly over 128 of the Black alumni belonged to the Black Altanni Organization. 
L.T. Smith (1987), I. H. Allen (1981) and J. H. Evans

(1986) found that there was a relationship between financial

support by African American alumi of their schools and their student experiences. Satisfaction with undergraduate experiences characterized donors who had attended the school on which I. H. Allen focused his research. His study involved a small, historically Black, church school. Smith, on the other hand, had Bowling Green State University as the subject of his work. He found that Black nondonors were more likely than their white counterparts to cite negative student experiences as their reason for not contributing to alumni solicitations.

For a number of years, Black alumi of the University of Missouri-Columbia, contributed at a much lower rate than did nonBlack alumni, around 78 contrasted to 148 for non-Black alumni (Office of Development, 1995). In 1998, 108 of Black alumi donated to university solicitations. By 2000 , slightly more than $20 \%$ of Black alumn-1 yere donors (K. Ming, University of MissouriColumbia, Office of Development, E-mail, March 28, 2000). This is an appreciable increase in the number of Black alumni donors. Whether this is a unique occurrence or the beginning of a trend will have to be seen over the coming years. Additionally, the average gift for Black alumni was much lower than for non-Black alumni. This, however, could be primarily a function of income and accumulated nealth.

I believe that determining the cause of behavior is extremely important and attitudes seem to be one of the most 
promising explanations of human conduct including that of donorship.

Despite the importance of historically Black universities and colleges to their community and the nation as a whole, until the last two decades, economic support of these institutions by their alumni was, in the main, notably absent. Because of the crucial role that she believed they played in the African American community-educating professionals and leaders, providing employment for scholars and administrators, fostering a climate in which people are able to develop the academic skills needed to succeed--Jeanette Hawkins Evans was dismayed at the fiscal problems threatening the continued existence of many historically Black colleges and universities (1986, pp. 1-5). Evans noted that lack of alumni support has been postulated as a crucial factor in the fiscal problems facing these institutions (p. 5). She sought to determine if donorship hinged on certain categories of attitudes Black alunni held toward their schools. The leadership style of the chancellor or president, the public image of the institution, the quantity and quality of correspondence sent by a school to Its alumni, alumni relations programs, student experiences, and attitudes toward fund raising efforts overall were the six attitudinal categories on which Evans focused her study (p. 24). Evans developed a questionnaire based on these categories which she mailed to six hundred alumni of six Black colleges and universities. The schools Evans chose were Elizabeth City State University, Morgan State University, 
Virginia State University, Bennett College, Saint Paul's College, and Shaw University. The selected schools represent a cross section of historically Black academies, including public and private as well as rural and urban institutions (pp. 24-25) . Grouped by year of graduation, a stratified random sample of six hundred individuals was identified using entries in the selected schools' alumni directories (pp. 24-28).

An initial mailing with a cover letter, the questionnaire, and a self-addressed, stamped envelope was sent to the sample. Two weeks after that mailing, a second mailing, including all of the items in the initial package plus a reminder and a return date, went out to all non-respondents. Finally, after another three weeks, sixty non-respondents were chosen at random and interviewed by telephone. These procedures were based on a model developed by Galfo and Miller (J. H. Evàns, 1986, p. 28). A graduate of each of the six selected schools who had been trained to encourage participation by other alumni, assisted Evans in this process (p. 54). Three hundred and sixty-two (53.68) of the sample responded (p. 54). Dr. Evans used the Kolmogorov-Smirnov one sample test to treat her data (p. 28). She found a significant relationship at the .05 level between financial giving of alumi and their attitudes toward their schools in each of the categories examined (p. 54).

Although, Evans did not discuss in detail how she developed the individual questions included in the survey, they were designed to determine, she wrote, the respondents' attitudes and 
to measure the "relationship between the dependent and independent variables" (p. 27). Alumni giving was Evans' dependent variable. Her independent variables were alumni perception of their school's chancellor or president, its image, the frequency and quality of its alumni correspondence, its alumni program, and their student experiences. Moreover, the categories of questions in the instrument reflect the beliefs many fundraisers have about the attitudes that determine individual willingness to donate to various charities (Haggberg, 1992; Hartsook, 1998; Mai, 1991; Squires, 1997). The credibility of the soliciting organization and its leadership, the quality and impact of solicitation materials as well as of the process itself, the sense of connection that the giver has to the organization or project in question, and an overall view of the institution's fund raising effarts are elements of the donor equation that researchers and experts in the field of giving have examined (Haggberg, 1992; Hartsook, 1998; Mai, 1991; Squires, 1997). J. H. Evans' interest in a school's leadership and image is reflective of concern with organizational credibility. In 1996, Bendapudi, Singh, and Bendapudi wrote that a charity's image was the "single most critical element of its promotional program" (p. 37). The quality and impact of solicitation materials and the solicitation process in general parallel issues of contact with the school and the alumi association. Student experience would certainly define a sense of connection or identification with an institution. Evans 
addressed the overall concern with the process of solicitation and its purpose in her concluding category. The six attitudinal categories in the Evans study seem to conform to what the experts view as important to the attitudinal construct underlying why people give or fail to give to various charities: leadership of the organization, its image, its solicitation materials, its development officials, the potential donors' sense of connection to the organization, and the potential donors' overall attitudes toward the organization's fund raising process and purpose (Haggberg, 1992; Hartsook, 1998; Mai, 1991; Squires, 1997).

Fishbein (1967) developed a behavior intentions model which postulates that intentions are highly correlated to behavior, stemming from an individual's attitude toward the behavior, social norms, and a motivation to comply with those norms. A number of researchers over the years conducted studies that demonstrated the positive relationship between attitudes and behavior and the ability to predict behavior based on attitudes (Bagozzi, 1981; Finlay, Trafimow, Jones, 1997; Maoi Olson, 1995; Morrison, Gillmore, Simpson, Wells, \& Hoppe, 1996). Gregory R. Maoi and James M. Olson (1995) found that "for subjects in the value-expressive attitude condition, values predicted intentions to donate even when attitudes, norms, and perception of control were entered into the equation" (p. 266). Moreover, some researchers found that changing attitudes can change behavior (Badovinac, 1994; Beach, 1984; Castle, 1952; 
Chapman, Ham, Liesen, \&inter, 1995; "Drink Drive Campaign," 1997; Flowers, Miller, Smith, Booraem, 1994; Hemsworth, Coleman, \& Barnett, 1994; Kempf, 1935). Donations fund, in whole or in part, the operations of various organizations including a number involved with education. Donations are critical to organizations relying upon them and to the populations they serve. Generating donorship and, concomitantly, understanding, at least in part, some of the factors underlying that process are essential to many organizations. The question of why individuals donate may be answered differently by various researchers. At least one researcher believed that the question was of yet largely unresolved (Dahl, 1981).

However attitudes are believed by a number of researchers to be the determinants of behavior. Several researchers even found that behavior may be changed by changing attitudes. Evans' research into the dynamics of attitudes in the context of donorship and the findings of such investigations by Evans and others have implications for those involved with philanthropy as practitioners or researchers and for experts in several related disciplines. Evans examined the relationship between attitudes and behavior relative to the graduates of several historically Black academic institutions. I sought to see what role attitudes might play in donorship for a historically and predominantly white institution. My study takes Black alumni attitude research into a new venue as well as another decade. 


\section{Susmary}

Education is a crucial element in the cultural, economic, political, and social structure of this nation. The pursuit of formal education by African Americans has been difficult during much of this nation's history. In most of the slaveholding states laws forbade the education of chattel. The force of societal expectations barred education to those in servitude in states that did not pass such legislation. In the free states, Blacks were frequently treated in a less than welcoming manner. Sometimes existing schools would not actmit them and when Blacks founded their own institutions, these were often burned to the ground. In 1849, the supreme Court, in Roberts v. Bostion, handed down a decision supporting segregated schools.

African Americans attended educational institutions founded by such groups as the Quakers and created their own as well. Colleges for Blacks were opened early in the nineteenth century. Black collegés at one time were responsible for many of the professionals who served the African American community, helped nurture its leadership, forge its middle class. Nevertheless, many of these institutions received little support from their alumni.

Despite popular wisdom to the contrary, middle class African Americans have money for discretionary spending and are as disposed to charitable pursuits as their white counterparts. The question of why Blacks have so miserably failed the 
educational institutions that nurtured them is one of great importance. Several researchers have addressed this question. My study was designed to examine Black alumni attitudes toward a public, largely white Midwestern research one institution. This may well be the first time that a primarily attitudinal study of Black alumni donorship has been undertaken relative to the class of institution represented by the University of MissouriColumbia. If attitudes are determinants of behavior as a number of researchers believe, and donations are important to many educational institutions, then research into the attitudes underlying donorship is definitely crucial. Moreover, my research contrasts and expands upon that previously done on Black alumni donorship and attitudes. 
CHAPTER III

Design of the study

Introduction

The main objective of this research was to examine the attitudes of the University of Missouri-Columbia's Black alumni toward the school. Concomitantly, the study attempted to assess whether and how donor status was reflected in attitudes. With the permission of its author, Jeanette Hawkins Evans, a questionnaire designed to research Black alumni donorship was used. (See Appendix C for the letter of permission.)

\section{Research Question, Hypothesis, and Statistical Analysis}

The following research question was addressed: Is the donor status of the University of Missouri-Columbia's Black alumi affected by their attitudes toward their student and alumni experiences relevant to the institution?

In analyzing the data obtained in the study, this hypothesis was tested:

H0: There is no statistically significant difference in the Black Alumi Survey's mean item score between donors and nondonors, Alphax.05.

The independent variable was donor status and the dependent variable was alumni attitudes. The Black Alumni Survey was 
structured as a Likert Scale. Rensis Likert wrote that such a scale "yielded a distribution resembling a normal distribution" (Likert, 1932, p. 21). ANOVA is a test to determine if the means of two or more groups are equal (Ferguson, 1981, p. 244; Stockburger, 1996). This study compared the means of donors and nondonors obtained through the Black Alumni Survey. Moreover, ANOVA is used with normal distributions such as are associated with a Likert Scale (Clark-Carter, 1997, pp. 239-249). ANOVA is an acceptable test for this study. Additionally, crosstabs with chi-square tests were performed on the demographic data for the responses to the attitudinal questions in the survey. Stockburger (1996) wrote that crosstabs are performed "to decide whether or not effects are present."

\section{Subjects}

The population for the study was 1,934. Of this number, 335 were randomly selected for the survey. The size of the sample was determined using the table developed by Krejcie and Morgan. Krejcie and Morgan's table was based on the National Education Association Research Division's formula for determining sample size for a population (Christensen, 1985, pp. 279-280). Although random selection resulted in the inclusion of an African alumni in the sample, the individual selected did not respond. Consequently, participants in this study are limited to African Americans. Forty-three surveys were returned due to incorrect addresses and other problems. In one case a recipient of the 
questionnaire was removed from the sample after identifying herself as being other than Black. Adjusting for these problems, the sample was 291 with a usable response rate of 141

questionnaires or approximately 498 of those actually contacted. The Black Alumni Survey was sent to individuals who attended the university from 1950 through 1995.

\section{Instrumentation}

A modified form of Jeanette Hawkins Evans' questionnaire was the instrument used to collect data for this study. Her survey included a total of 34 questions, five of which were designed to gather demographic information. Dr. Evans had 10 historically Black college alumni evaluate the proposed questionnaire for clarity of wording and content validity: Additionally, 16 students enrolled in graduate level classes at Morgan State University plus three members of Evans' doctoral committee-all of whom had had coursework in research methodologywere also invited.to review and comment on the instrument. The Evans survey is not a generally recognized standardized test with unquestioned validity and reliability. However, a review of the literature did not disclose a standardized instrument to measure Black alumni donorship attitudes, the focus of my research, or one even specifically concerned with alumi donorship attitudes. A number of those who researched alumi donorship developed their own instruments, as did Evans (Anderson, 1981; Beeler, 1982; Burnett, 1981; House, 1987; Keller, 1982; Korvas, 1984; Roberts, 
1999; Robinson, 1994; Rosser, 1997; Shorb, 1983; Wetta, 1990). No other questionnaire was designed to deal specifically with alumni attitudes; only the Evans survey did so. Since alumi attitudes as the determinants of donorship were the focus of this study, Evans' instrument was the most suitable. Additionally, this was an opportunity to test the Evans instrument on another sample. Furthermore, Evans' questionnaire while examining a range of attitudinal issues was relatively short, considered desirable in a survey instrument (De Vaus, 1995, p. 109; Fink \& Kosecoff, 1998, p. 31), lent itself easily to modification, had been used on a similar population to the one in which I was interested, and had been efficacious for Dr. Evans.

Slight modifications were made to the Evans instrument. Alumni of six historically Black colleges took part in Evans' study. She included a question that asked for the name of the school the respondent attended. This question vas eliminated. Since all the respondents to my study were alumni of the University of Missouri, it was of course not necessary to ask which college or university each had attended. In those instances in which the questionnaire referred to undergraduate experiences, the questions were reworded to reflect student experience in general. Black alumi of the University of Missouri include individuals who attended the school as undergraduates, graduates, and professional students. The section concerned with correspondence from the school was retitled to reflect various means of contact (e.g., mail, 
telephone, and face-to-face). The Black Alumni Survey-the designation for the form of the Evans questionnaire used in my research-was pre-tested on 10 individuals whose backgrounds included coursework in research methodology.

Because of its practicality, standardization, and relative economy in terms of time and expense, the questionnaire is a sound research instrument for a study of this sort (Tuckman, 1978, p. 197). The questionnaire format was a Likert scale. Nunnally argued that the Likert scale is notable for its reliability, enabling the researcher to order responses ranging across polar extremes, yet allowing at the same time for feelings of neutrality (1967, p. 531). Babbie (1986) praised the scale for "the unambiguous ordinality of its response categories" ( $p$. 375). Moreover, he found it to have "a greater rigor and structure than other question formats" (p. 376). The basic structure of the questionnaire used for this study included:

Section 1 - five questions focused on whether giving was influenced by perceptions of the manner in which the chancellor discharged his duties.

Section 2 - six questions focused on whether giving was influenced by perceptions of institutional image. 
Section 3 - four questions focused on whether giving was influenced by perceptions of the quality of institutional correspondence.

Section 4 - three questions focused on whether giving was influenced by perceptions of alumni association performance.

Section 5 - six questions focused on whether giving was influenced by perceptions of student experiences.

Section 6 - four questions focused on whether giving was influenced by perceptions of general fund raising practices.

The questionnaire included these twenty-eight questions plus five questions used to gather demographic data. This instrument was pre-tested and modified accordingly. (See Appendix A for a copy of the instrumentation.)

\section{Data Collection}

The population for the study was the 1,934 Black alumni who attended the University of Missouri-Columbia from 1950 through 1995 as shown on a printout provided by the office of Development (1996). The questionnaire was mailed to 335 alumni, randomly selected from the population of 1,934 . 
Mailing of the survey instrument was based on procedures recommended by Dillman (1978), and Salant and Dillman (1994, p. 148) as described hereafter. A copy of the survey together with a cover letter and self-addressed (the researcher's address) stamped envelope was sent to 335 Black alumi. About twelve days later a postcard was mailed: thanking those who had already returned the survey, reminding those who had not, and offering to send a second survey to those who might have misplaced or not received the original mailing. Slightly less than a month later, another survey, cover letter, and self-addressed stamped envelope was sent to those who had not already returned the survey. A little less than two months later, a final survey, cover letter, and self-addressed stamped envelope were sent by certified mail to those who had not responded to the preceding mailings. (See Appendix B for the cover letters and postcard).

\section{Demagraphic Data}

Various demographic data was summarized in tables, serving as a descriptive portrayal of the study's sample. These tables include :

Table 1 - Percentage Distribution of the 1,934 Population by Sex

Table 2- Percentage Distribution of 335 Selected for Survey by $\operatorname{sex}$

Table 3 - Percentage Distribution of Sample by Sex and Donor Status 
Table 4 - Percentage Distribution of Donors by Sex and Geographic Location

Table 5 - Percentage Distribution of Nondonors by Sex and Geographic Location

Table 6 - Percentage-Distribution by MU Degree and Donor Status

Table 7 - Percentage Distribution by Highest Degree Held from Any Institution and Donor Status

Table 8 - Percentage Distribution by Marital and Donor Status

Table 9 - Percentage Distribution by Age and Donor Status Table 10 - Percentage Distribution by Income and Donor Status

\section{Justification for the Study}

An examination of the attitudes, alumni affiliations, and institutional giving of African Americans who graduated from the university from 1950 through 1995 using the Black Alumni Survey is desirable for several reasons:

Since there has been such a limited amount of research specific to the attitudes of Black alumni and how those attitudes affect their willingness to donate to their schools, it was good that such research relevant to a large predominantly white public institution could be conducted. Certain other studies have investigated Black alumni attitudes and giving patterns in relation, usually, to Black colleges, church schools, and private 
institutions. Larry T. Smith's 1987 study at Bowling Green State University was an exception. Aluani donorship in general and Black alumni donorship in particular should become increasingly important subjects for universities. This study may provide some insight into the attitudes of Black alumni of a large, important research institution.

The Evans instrument was deemed suitable for this study. A number of other tests and questionnaires used to determine alumni perceptions were examined. Each instrument had positive and negative points. Dr. Evans' instrument seemed best for the purposes of this study for several reasons. First, the basic instrument was used on a sample similar in many respects to that included in my study. Second, while brief, the instrument addresses issues critical to the concerns of my study. Third, each question is short, clear, and to the point. These of course are highly desirable attributes in a survey instrument (Babbie, 1989, p. 143). Fourth, the instrument was easily modified to make it appropriate to my study.

\section{Limitations of the Study}

The results of this study represents a sample of Black alumni of the University of Missouri-Columbia--also referred to as Mizzou, MU, and the University of Missouri--who attended between 1950 and 1995, and were willing to complete and return the survey. 
CHAPTER IV

\section{Presentation and Analysis of Findings}

\section{$\underline{\text { Introduction }}$}

This chapter summarizes the results of analysis of the Black Alumni Survey. The questionnaire was composed as a single scale which has an associated hypothesis. For this hypothesis, the descriptive statistics are presented, disaggregated by the two levels of the independent variable (i.e., donor and nondonor). The descriptive statistics section is followed by a brief section where the scale's reliability is discussed. Following the descriptive statistics, an ANOVA table is presented, followed by a short summary of the results. The characteristics of the sample will be shown in the first 10 tables.

The total number of living MU graduates in 1995 was 153,320 of which 1,934 or approximately 18 was Black. About 18 (857) of the 87,051 male alumni were Black; 1,077 (28) of the 66,269 female alumni were Black. Table 1 shows gender and donorship data for the population.

Table 1

Percentage Distribution of the 1,934 Population by Sex

\begin{tabular}{lrrrr}
\hline Sex & \multicolumn{1}{c}{$\underline{N}(8)$} & Donors & $(8)$ \\
\hline Male & 857 & $(448)$ & 58 & $(488)$ \\
Female & 1,077 & $(568)$ & 63 & $(528)$ \\
\hline Total & & 1,934 & & 121 \\
\hline
\end{tabular}


of the 1,934 living Black alumni, 335 were contacted to participate in the study. Males represented 132 (398) of this group and females 203 (618). Table 2 shows the percentage distribution by sex of the 335 selected for the study.

Table 2

Percentage Distribution of 335 Selected for Survey by Sex

\begin{tabular}{lcl}
\hline Sex & $\underline{N}(z)$ \\
\hline Male & 132 & $(398)$ \\
Female & 203 & $(618)$ \\
\hline Total & & 335 \\
\hline
\end{tabular}

One hundred forty-one (42\%) alumni responded of the 335 contacted. Of these, 50 (358) were males and 91 (65\%) were females. Fifty-seven (40\%) of the 141 member sample were donors while 84 (60\%) were nondonors. Table 3 shows the percentage distribution of the sample by gender and donor status.

Table 3

Percentage Distribution of Sample by Sex \& Donor Status

\begin{tabular}{lrrrrrr}
\hline Sex & \multicolumn{1}{c}{ N $(8)$} & \multicolumn{1}{c}{ Donor $(8)$} & Nondonor $(8)$ \\
\hline Male & 50 & $(358)$ & 23 & $(408)$ & 27 & $(328)$ \\
Female & 91 & $(658)$ & 34 & $(608)$ & 57 & $(688)$ \\
\hline Total & & 141 & & 57 & & 84 \\
\hline
\end{tabular}

of the total 57 donors, 36 (638) lived in Missouri, while 21 (378) lived outside of the state. Table 4 shows percentage distribution of donors by sex and geographic location. 
Table 4

Percentage Distribution of Donors by Sex \& Geographic Location

\begin{tabular}{lrlrr}
\hline Sex & Missouri & $(8)$ & Outside Missouri & $(8)$ \\
\hline Male & 12 & $(338)$ & 11 & $(528)$ \\
Female & 24 & $(678)$ & 10 & $(488)$ \\
\hline Total & & 36 & & 21 \\
\hline
\end{tabular}

of the total 84 nondonors, 43 (518) lived in Missouri while 41 (498) lived outside of the state. Table 5 shows percentage distribution of nondonors by sex and geographic location.

Table 5 Percentage Distribution of Nondonors by Sex \& Geographic Location

\begin{tabular}{lrrrr}
\hline Sex & Missouri $(8)$ & Outside Missouri $(8)$ \\
\hline Male & $10(238)$ & 17 & $(418)$ \\
Female & $33(778)$ & 24 & $(598)$ \\
\hline Total & & 43 & 41 \\
\hline
\end{tabular}

Eighty-nine (63\%) of the respondents obtained their bachelors' degrees from the university while 52 (37\%) of the respondents obtained a graduate degree from the school. Of the 89 who received a bachelor's degree from the school 33 (378) were donors while $56(63 \%)$ were nondonors. Of the 52 who received a graduate degree from the school 24 (46\%) donors while 28 (548) were nondonors. Table 6 shows percentage distribution by MU degree and donorship. 
Table 6

Percentage Distribution by MU Degree \& Donor Status

\begin{tabular}{|c|c|c|c|}
\hline Degree & $\underline{N}(z)$ & Donor $(8)$ & Nondonor (8) \\
\hline Bachelor & $89(638)$ & $33(587)$ & $56(678)$ \\
\hline Graduate & $(378)$ & $24(428)$ & $28 \quad(338)$ \\
\hline Total & 141 & 57 & 84 \\
\hline
\end{tabular}

Fifteen (118) of the 141 member sample obtained more than one degree from the university with several obtaining three degrees. These 15 respondents were of course also counted with either the bachelor or graduate respondents, depending on the highest level degree awarded by the university in an individual instance. For example, several individuals received two bachelor's degrees from the school. In those cases, of course, these individuals were counted with the bachelor level respondents. Those who received two graduate or a bachelor and graduate degree from the school were counted with graduate degree respondents for the purposes of this descriptive analysis. The fifteen respondents who hold multiple degrees from the institution are almost equally divided between donors and . nondonors with 7 (478) donors and 8 (538) nondonors.

While 89 of the respondents received a bachelor's degree from the school, only $53(388)$ of the 141 respondents indicated that a bachelor's degree was the highest level of education that they had attained. Further, while 52 (37\%) of the sample had obtained a graduate degree from the University of MissouriColumbia, 81 (57\%) held graduate degrees. Two (18) of the sample 
were classed as other. Five (48) did not indicate educational level. Of the 53 respondents who reported that a bachelor's degree was the highest degree that they held, 17 (328) were donors while $36(68 \%)$ were nondonors. Of the 81 respondents who reported that a graduate degree was the highest degree that they held, $36(448)$ were donors while 45 (568) were nondonors. Table 7 shows percentage distribution by highest degree held from any institution and donor status.

Table 7

Percentage Distribution by Highest Degree Held from Any Institution \& Donor Status

\begin{tabular}{lrlcccc}
\hline Degree & $\underline{N}$ & $(8)$ & Donor $(8)$ & Nondonors $(8)$ \\
\hline Bachelor & 53 & $(388)$ & 17 & $(328)$ & 36 & $(448)$ \\
Graduate & 81 & $(578)$ & 36 & $(688)$ & 45 & $(568)$ \\
Other & 2 & $(18)$ & 0 & $(08)$ & 0 & $(08)$ \\
Unknown & 5 & $(48)$ & 0 & $(08)$ & 0 & $(08)$ \\
\hline Total & & 141 & & 53 & 81 \\
\hline
\end{tabular}

Sixty-three (458) of the respondents were single; 59 (428) of the respondents were married; 7 (58) were separated; and 12 (88) of the sample did not indicate their marital status. Of the 63 single respondents, 18 (298) were donors while 45 (718) were nondonors. Of the 59 married respondents, 28 (478) were donors while 31 (538) were nondonors. Of the 7 separated respondents, 5 (718) were donors while 2 (298) were nondonors. Table 8 shows percentage distribution by marital status and donorship. 
Table 8

Percentage Distribution by Marital Status \& Donor Status

\begin{tabular}{lrlrlrl}
\hline Marital Status & \multicolumn{1}{c}{$\mathbf{N}(8)$} & Donor & $(8)$ & Nondonor & $(8)$. \\
\hline Single & 63 & $(458)$ & 18 & $(358)$ & 45 & $(588)$ \\
Married & 59 & $(428)$ & 28 & $(558)$ & 31 & $(408)$ \\
Separated & 7 & $(58)$ & 5 & $(108)$ & 2 & $(28)$ \\
Unknown & 12 & $(88)$ & 0 & $(08)$ & 0 & $(08)$ \\
\hline Total & \multicolumn{7}{c}{141} & & 51 & & 78 \\
\hline
\end{tabular}

Two (18) of the sample were less than 25 years old; 37 (268) were between 25-29 years of age; 27 (198) were between 30$34 ; 23$ (168) were between 35-39; 17 (128) were between 40-44; 14 (108) were between 45-49; 7 (58) were between 50-54; 9 (68) .were over $55 ; 5(48)$ of the sample did not respond to the question of age. Of the 2 participants less than 25 years old, neither $(0 \%)$ were donors and $2(1008)$ were nondonors. Of the 37 participants 25-29 years old, 7 (198) were donors and 30 (818) were nondonors. of the 27 participants 30-34 years old, 11 (41\%) were donors and 16 (598) were nondonors. Of the 23 participants 35-39 years old, 10 (438) were donors and 13 (578) were nondonors. Of the 17 participants 40-44 years old, 9 (538) were donors and 8 (478) were nondonors. Of the 14 participants 45-49 years old, 6 (438) were donors and 8 (578) were nondonors. Of the 7 participants 50-54 years old, $3(438)$ were donors and 4 (578) were nondonors. of the 9 participants 55 or older, 8 (898) were donors and 1 (118) was a nondonor. Table 9 shows percentage distribution by age and donor status. 
Table 9

Percentage Distribution by Age \& Donor Status

\begin{tabular}{|c|c|c|c|}
\hline Age & $\underline{N}(8)$ & Donor (8) & Nondonors $(8)$ \\
\hline$<25$ & $2(18)$ & $\begin{array}{ll}0 & (08)\end{array}$ & $2(28)$ \\
\hline $25-29$ & $37(268)$ & 7 (138) & $30 \quad(378)$ \\
\hline $30-34$ & 27 (198) & 11 (208) & 16 (198) \\
\hline $35-39$ & $23(168)$ & $10(188)$ & $13(168)$ \\
\hline $40-44$ & $17(128)$ & $9(178)$ & $8(108)$ \\
\hline $45-49$ & 14 (108) & $6(118)$ & $8(108)$ \\
\hline $50-54$ & $7(58)$ & $3(68)$ & $4 \quad(58)$ \\
\hline$>55$ & $9(68)$ & $8(158)$ & 1 (18) \\
\hline Unknown & $5(48)$ & $0(08)$ & $0 \quad(08)$ \\
\hline Total & $\overline{141}$ & $\overline{54}$ & $\overline{82}$ \\
\hline
\end{tabular}

Eight (68) of the sample earned incomes of less than

$\$ 15,000$ per year; 2 (18) earned incomes between $\$ 15,000-\$ 19,999$

per year; $8(68)$ earned incomes between $\$ 20,000-\$ 24,999$ per year;

21 (158) earned incomes between $\$ 25,000-\$ 34,999$ per year; 33

(238) earned incomes between $\$ 35,000-\$ 50,000$ per year; 64 (458)

earned incomes over $\$ 50,000$ per year; 5 (48) did not respond to

the question to determine income range. Of the 8 participants

with incomes of less than $\$ 15,0000$ a year, 1 (128) was a donor and 7 (888) were nondonors. Of the 2 participants with incomes of $\$ 15,000-19,999$ a year, neither (08) were donors 2 (1008) were nondonors. Of the 8 participants with incomes of $\$ 20,0000-24,999$ a year, 1 (128) was a donor and 7 (888) were nondonors. of the 21 participants with incomes of $\$ 25,000-24,999$ a year, 4 (198) were donors and 17 (818) were nondonors. Of the 33 participants 
with incomes of $\$ 35,0000-50,000$ a year, 10 (308) were donors and $23(708)$ were nondonors. Of the 64 participants with incomes of $\$ 50,000$ or more a year, 38 (598) were donors and 26 (418) were nondonors. Table 10 shows percentage distribution by income and donor status.

Table 10

Percentage Distribution by Income \& Donor Status

\begin{tabular}{|c|c|c|c|}
\hline Income & $\underline{N}(\boldsymbol{q})$ & Donor $(8)$ & Nondonor (8) \\
\hline$<\$ 15000$ & $8\left(6 \frac{8}{8}\right)$ & $(28)$ & $7(88)$ \\
\hline$\$ 15,000-19,999$ & $2(18)$ & $(08)$ & $2(28)$ \\
\hline$\$ 20,000-24,999$ & $8(6 \%)$ & (28) & $7(88)$ \\
\hline$\$ 25,000-34,999$ & $21(158)$ & $(78)$ & 17 (218) \\
\hline$\$ 35,000-50,000$ & 33 (238) & 10 (198) & $23(288)$ \\
\hline$>\$ 50,000$ & $64(458)$ & $(70 \%)$ & $(328)$ \\
\hline Unknown & $5\left(4 \frac{8}{8}\right)$ & $(08)$ & $(08)$ \\
\hline Total & 141 & 54 & 82 \\
\hline
\end{tabular}

Crosstabs with chi-square tests were performed on demographic data (i.e., gender and donor status), for the responses to the attitudinal questions in the survey to discover statistical significance when the demographic categories were combined. Only 2 questions showed significance at the .058 level of confidence: 15 and 18. Crosstabs were also run for age, income, marital status, and educational attainment. However, these did not prove significant. Nevertheless, the 568 donorship rate for those earning $\$ 50,000$ per year or more was so striking that an additional statistical test was performed. One-way ANOVA was performed on income level data for responses to the 
attitudinal test. Significance was found for questions 12 and 14. These findings are discussed in Chapter 5.

Table 11 shows the crosstabs with chi-square test for Question 15, a Likert scale providing responses strongly disagree, disagree, agree and strongly agree. Question 15 stated, "The frequency and clarity of the correspondence from Mizzou has significant influence on my financial giving." The crosstabs showed that this did not matter to nondonor females. Forty-one females disagreed with the statement while only 11 agreed. On the other hand, 14 males disagreed while 11 agreed. The Pearson chi-square . was .031 and less than .05 which indicates that the rows and columns of the contingency are dependent.

Table 11 Donors and Nondonors, Males and Females, Question 15

\begin{tabular}{|c|c|c|c|c|c|c|}
\hline \multirow{2}{*}{$\begin{array}{l}\text { Donor } \\
\text { status }\end{array}$} & \multicolumn{3}{|c|}{ strong } & \multicolumn{3}{|c|}{ strong } \\
\hline & Sex & disagree & Disagree & Agree & agree & Total \\
\hline & $\mathbf{M}$ & 1 & 9 & 9 & 2 & 21 \\
\hline \multirow[t]{2}{*}{ Donor } & $\mathbf{F}$ & 5 & 17 & 8 & 1 & 31 \\
\hline & Total & 6 & 26 & 17 & 3 & 52 \\
\hline \multirow{3}{*}{$\begin{array}{l}\text { Non- } \\
\text { donor }\end{array}$} & $\mathbf{M}$ & 5 & 9 & 11 & & 25 \\
\hline & $\mathbf{F}$ & 10 & 31 & 8 & 3 & 52 \\
\hline & Total & 15 & 40 & 19 & 3 & 77 \\
\hline
\end{tabular}


Table 12 shows the crosstabs with chi-square test for Question 18, a Likert scale providing responses strongly disagree, disagree, agree and strongly agree. Question 18 stated, "The quality of the Alumni Association at Mizzou has significant influence on my financial giving." The crosstabs showed that this was of concern to donor males while it did not concern donor females. Thirteen males agreed with the statement while 8 disagreed. On the other hand, 9 females agreed while 19 disagreed. The Pearson chi-square was .031 and less than .05 which indicates that the rows and colunns of the contingency are dependent.

Table 12

Donors and Nondonors, Males and Females, Question 18

\begin{tabular}{|c|c|c|c|c|c|c|}
\hline \multirow{2}{*}{$\begin{array}{l}\text { Donor } \\
\text { status }\end{array}$} & \multicolumn{3}{|c|}{ Strong } & \multicolumn{3}{|c|}{ Strong } \\
\hline & Sex & disagree & Disagree & Agree & agree & Total \\
\hline \multirow{3}{*}{ Donor } & $\mathbf{M}$ & $\overline{1}$ & 7 & 12 & $\overline{1}$ & 21 \\
\hline & $\mathbf{F}$ & 5 & 14 & 5 & 4 & 28 \\
\hline & Total & 6 & 21 & 17 & 5 & 49 \\
\hline \multirow{3}{*}{$\begin{array}{l}\text { Non- } \\
\text { donor }\end{array}$} & $\bar{M}$ & 2 & 11 & 8 & & 21 \\
\hline & $\mathbf{F}$ & 8 & 27 & 14 & 3 & 52 \\
\hline & Total & 10 & 38 & 22 & 3 & 73 \\
\hline
\end{tabular}




\section{Results of Data for Alumni Attitudes}

The questionnaire asked the alumni to what degree they thought that certain factors influenced their attitudes toward the University of Missouri-Columbia (see Appendix A). Alumni were given the options of responding to the questions as "strongly agree," "agree," "disagree," "strongly disagree." (See Table 13 for alumni responses).

The responses of alumni who answered the question by checking the response "strongly agree" or the response "agree" were combined and interpreted as "agree." The responses of alumni who answered a question by checking the response . "disagree" or the response "strongly disagree" were combined as "disagree." The responses were:

For question 1 , "effectiveness of chancellor," 65 alumni agreed that the chancellor was an effective leader while 9 found his leadership lacking. Sixty-seven alumi did not respond to this question.

For question $" 2$, "comunication skills of the chancellor," 64 alumni felt that the chancellor was an effective communicator and 10 alumni dissented. Sixty-seven alumni again did not answer this question.

For question \#3, "organizational skills of the chancellor," 65 alumi felt that the chancellor was an effective manager while 5 disagreed. Seventy-one alumi did not answer this question. For question \$4, "chancellor should continue in role," 61 alumni agreed that the chancellor should continue as the leader 
of Mizzou while 10 did not. Seventy alumi did not answer this question.

For question $\# 5$, "inpression of chancellor influences giving," 27 alumi agreed that their impressions of the chancellor influenced theit giving; 71 did not agree. Fortythree alumi did not answer this question.

For question \$6, "Mizzou is nationally" respected," 115 alumni agreed that the university was nationally respected for its programs and services while 19 did not dgree.' Seven alumni did not answer the question.

For question $\$ 7$, "Mizzou attracts highly acadenic students, " 123 alumi agreed while 10 did not agree. Eight alumni did not answer the question.

For question \$8, "gatigfied with Mizzou's fiscal management," 93 aluni agreed that the university's fiscal management was satisfactory while 14 disagreed. Thirty-four alumni did not answer this question.

For question *9, "quality of education at Mizzou has always been competitive," 126 alumni agreed that the quality of education at the university has always been competitive while 8 alumni disagreed. Seven alumi did not answer this question.

For question $\$ 10$, media coverage of programs and events at Mizzou is positive" 107 alumi agreed while 16 alumi disagreed. Eighteen alumi did wot anbarer thi's question. 
For question 11 , "the perceived public image of Mizzou has a significant influence on my giving," 41 alumi agreed while 96 disagreed. Four did not answer this question.

For question 12 , "I an kept informed about Mizzou's programs and services," 106 aluani agreed and 33 disagreed. Two alumni did not answer this question.

For question \#13, "I receive regular memoranda concerning the fiscal needs of Mizzou," 77 alumni agreed while 59 alumi disagreed. Five alumni did not answer the question.

For question 14, "written comunications from Mizzou are clear and informative," 118 alumni agreed while 20 disagreed. Three alumni did not answer this question.

For question 15 , "frequency and clarity of the correspondence from Mizzou has significant influence on my financial giving," 42 alumi agreed while 97 disagreed. Twelve alumni did not answer this question.

For question 16 , "Alumi Association uses various means (newsletter, phonathons, meetings) to keep alumni informed," 119 alumni agreed while 17 disagreed. Five alumni did not answer this question.

For question 17 , "leaders of the Alumi Assoclation are effective managers and organizers, " 87 alumni agreed while 17 disagreed. Thirty-seven alumnl did not answer this question. For question $\# 18$, "quality of Alumn Assoclation has influence on my glving, 47 atuni agreed while 75 disagreed. Nineteen alumni did not answer this question. 
For question \#19, "my course work was interesting and challenging," 129 alumni agreed while 8 disagreed. Four alumni did not answer this question.

For question *20, "my campus experiences included a variety of cultural and social activities. which enhanced my educational experiences," 80 alumni agreed while 60 disagreed. One did not answer this question.

For question \#21, "my instructors/professors demonstrated genuine interest in my education," 100, alumni agreed while 36 disagreed. Five alumni did not answer this question.

For question *22, "my experiences at Mizzou overall are positive," 112 alumni agreed while 26 disagreed. Three alumni did not answer this question.

For question \#23, "my education adequately prepared me for the world of work," 123 alumni agreed while 13 disagreed. Five alumni did not answer this question.

For question *24, "quality of my educational experiences has a significant influence on my annual giving," 80 alumni agreed while 58 disagreed. Three did not answer the question.

For question *25, "chancellor needs to be more involved in alumni solicitation," 51 alumni agreed while 55 disagreed. Thirty-five alumni did not answer the question.

For question \#26, "purpose of fund raising should be more clearly defined," 102 alumni agreed while 21 disagreed. Eighteen alumni did not answer the question. 
For question \#27, "Mizzou needs a better marketing program," 100 alumni agreed while 20 disagreed. Twenty-one alumni did not answer the question.

For question *28, "my financial contribution will improve Mizzou's curricula," 52 alumni agreed while 62 disagreed. Twenty-seven alumni did not answer this question. 
Table 13

Alumni Attitudes

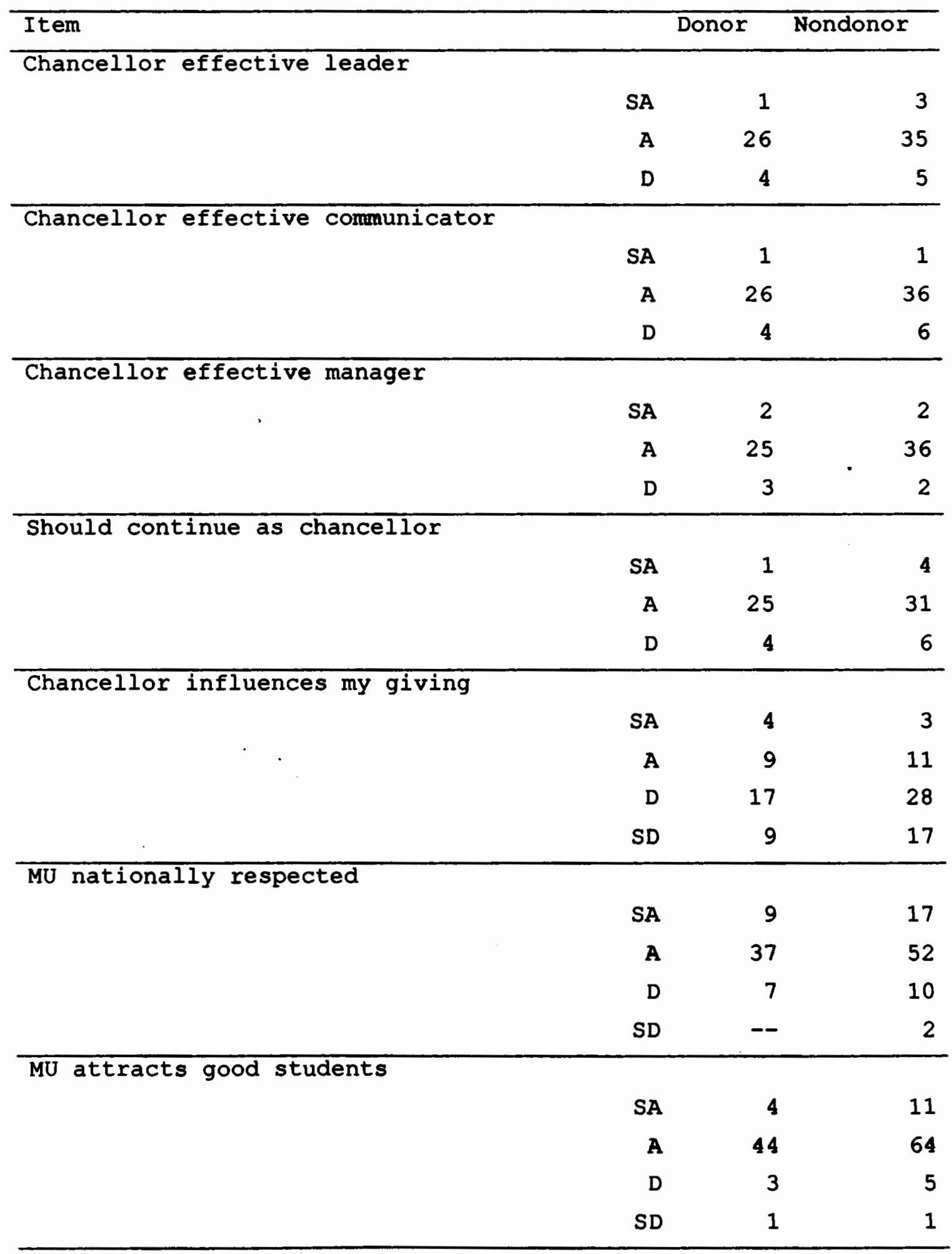


Table 13 (continued)

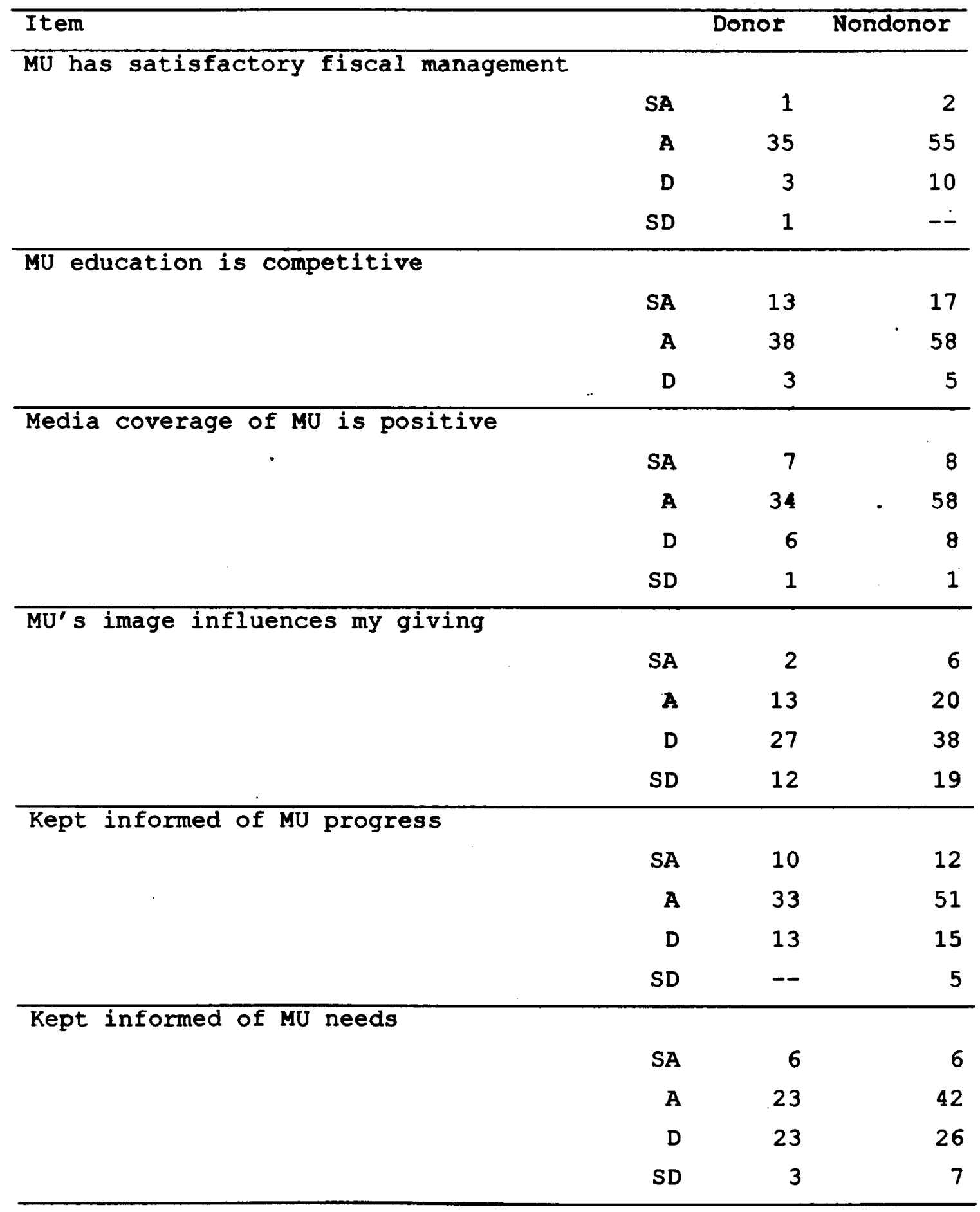


Table 13 (continued)

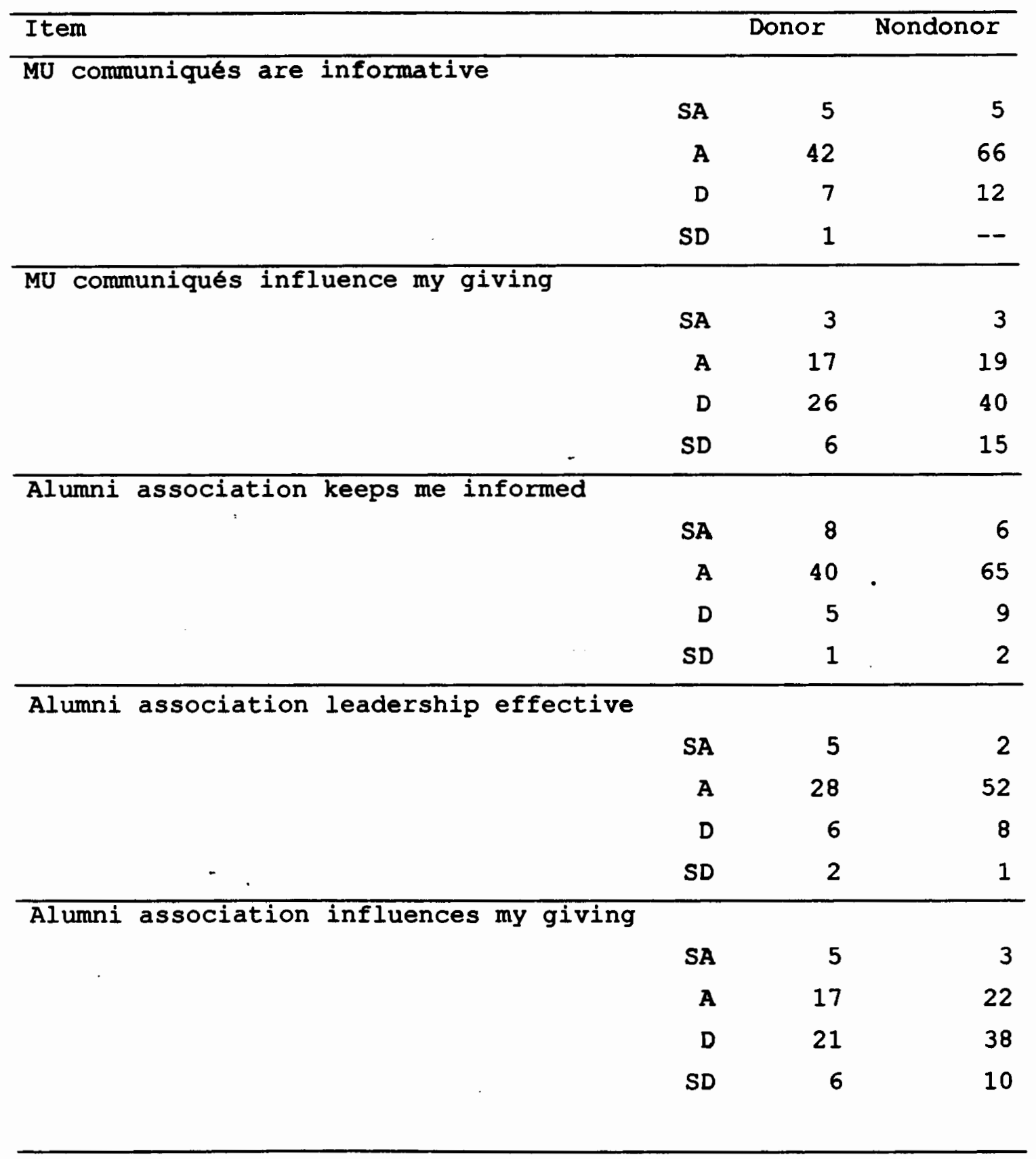


Table 13 (continued)

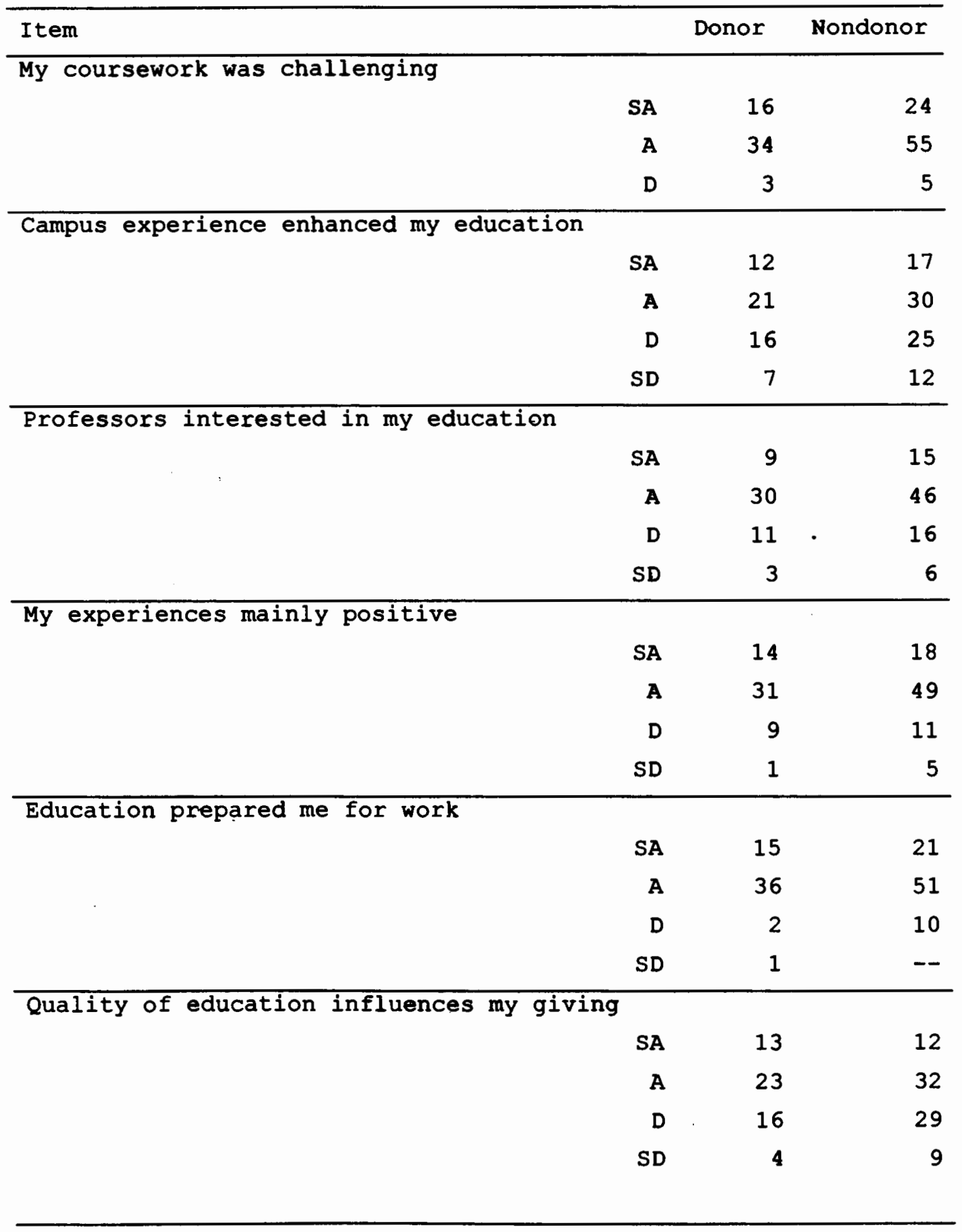


Table 13 (continued)

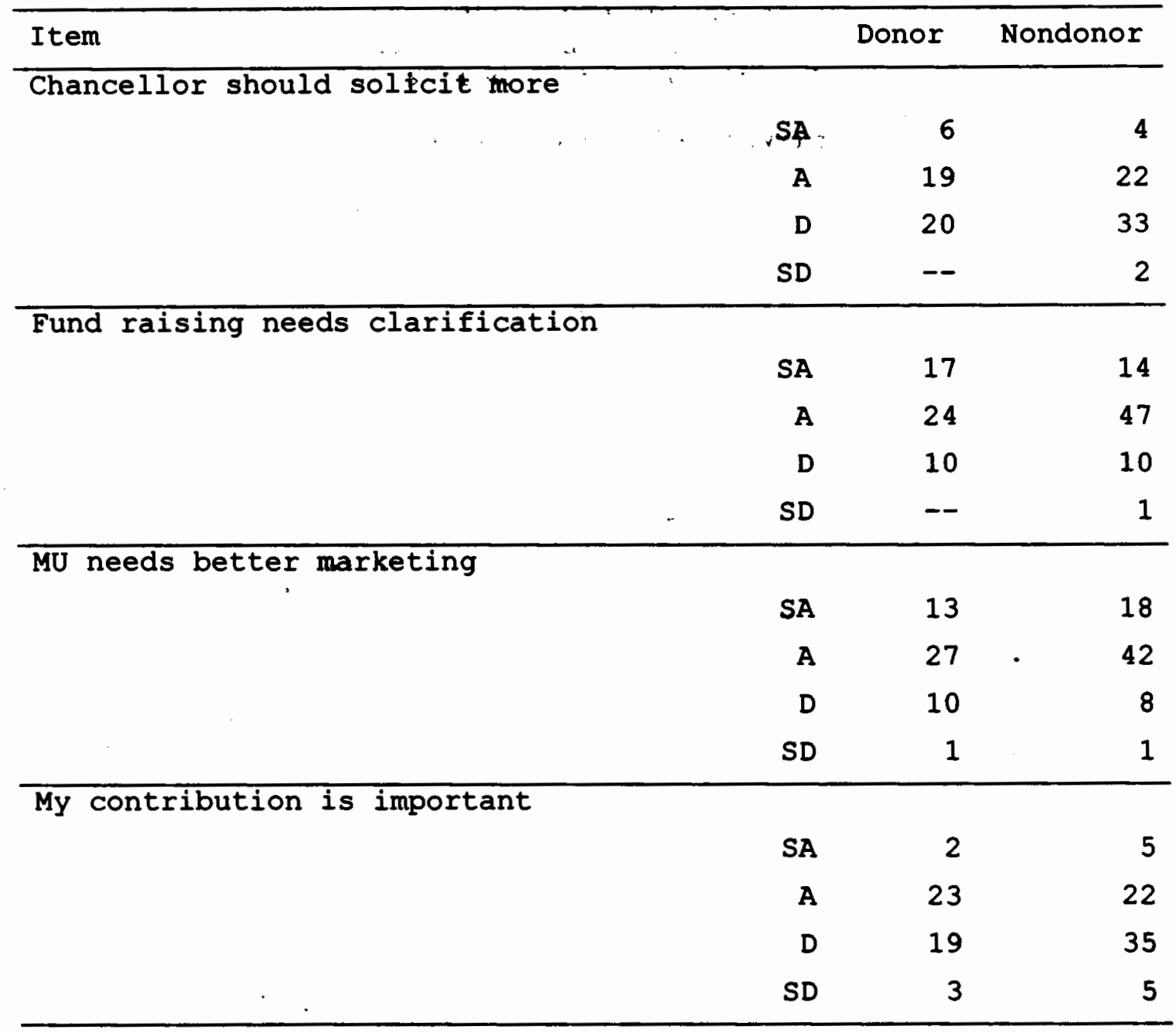

\section{Statistical Procedures}

Hypothesis 1: $\mathrm{H}_{01}$ : There is no statistically significant difference in the Black Alumni Survey's mean item score between donors and nondonors, alpha $=.05$.

This study sought to determine whether attitudes affected donorship. The reliability for the items included for analysis was a Cronbach's Alpha of .81, which is acceptable for creating additive and/or averaged scales. 
Cronbach's coefficient alpha $(\alpha)$ is a general form of the K-R 20 formula that can be used when items on a measure are not scored dichotomously. For example, some multiple-choice tests and essay tests include items that have several possible answers, each of which is given a different weight. Alpha is the appropriate method for computing reliability. (Borg \& Gall, 1983, p. 285)

Table 14

Reliability Summary for the Black Alumni Survey by Item

Scale

$\begin{array}{crcc}\text { Scale Mean } & \text { Variance If } & \text { Corrected } & \text { Alpha If } \\ \text { If Item } & \text { Item . } & \text { Item-Total } & \text { Item }\end{array}$

Item Deleted Deleted Correlation Deleted

\begin{tabular}{lllll}
\hline Q1 & 76.82 & 49.56 & 0.42 & 0.80 \\
Q2 & 76.84 & 49.65 & 0.43 & 0.80 \\
Q3 & 76.77 & 49.62 & 0.49 & 0.80 \\
Q4 & 76.82 & 49.56 & 0.38 & 0.80 \\
Q5 & 77.53 & 46.47 & 0.43 & 0.79 \\
Q6 & 76.60 & 49.17 & 0.30 & 0.80 \\
$Q 7$ & 76.69 & 50.60 & 0.23 & 0.80 \\
$Q 8$ & 76.85 & 51.54 & 0.07 & 0.81 \\
$Q 9$ & 76.53 & 48.92 & 0.36 & 0.80 \\
$Q 10$ & 76.71 & 49.53 & 0.29 & 0.80 \\
$Q 11$ & 77.61 & 47.72 & 0.36 & 0.80 \\
Q12 & 76.88 & 49.90 & 0.17 & 0.80 \\
Q13 & 77.12 & 47.98 & 0.33 & 0.80 \\
Q14 & 76.80 & 49.47 & 0.34 & 0.80 \\
Q15 & 77.42 & 45.57 & 0.55 & 0.79 \\
\hline
\end{tabular}


Table 15

Item Descriptive Statistics Summary for the Black Alumni

Donor Survey, by Item

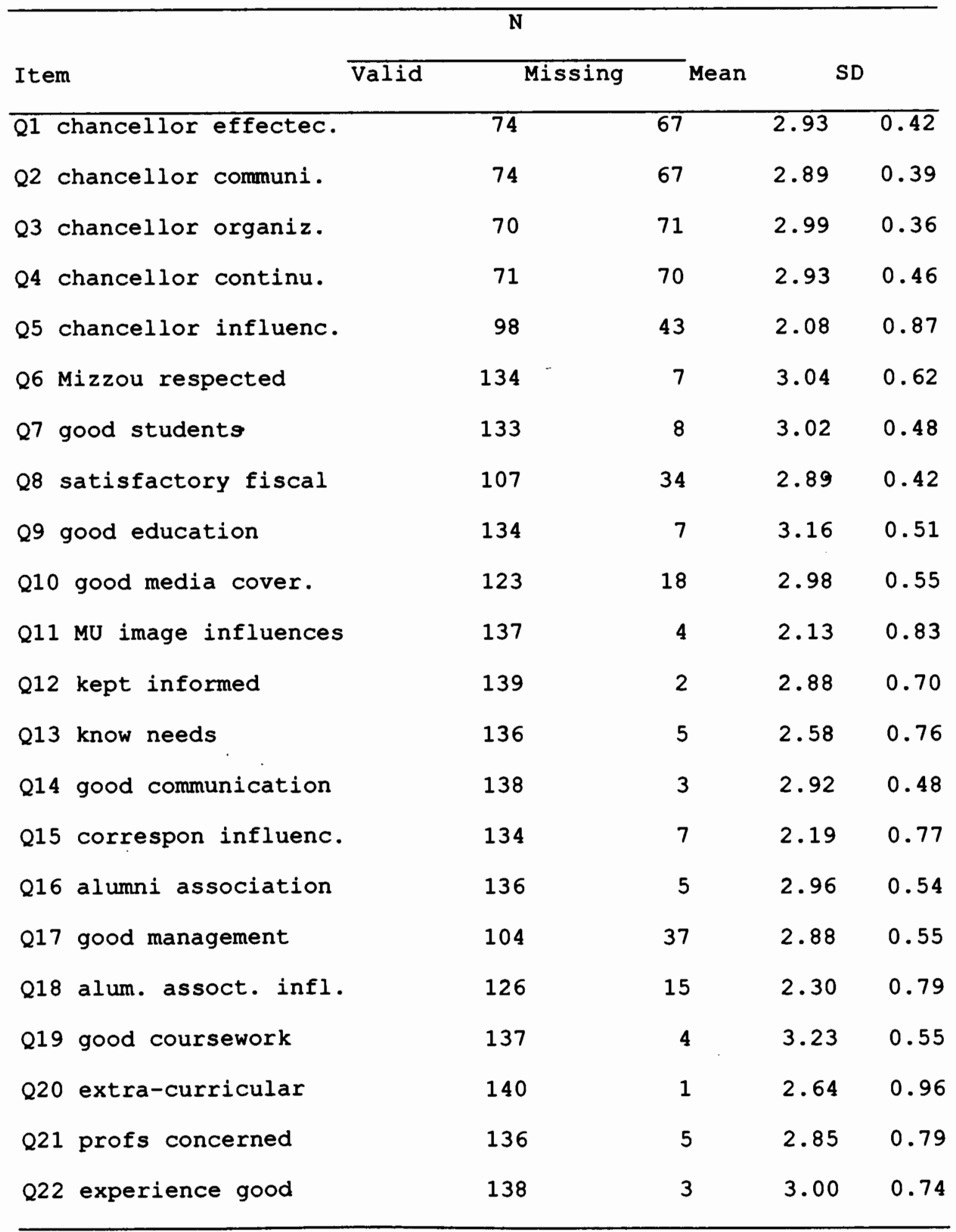


Table 15 (continued)

\begin{tabular}{|c|c|c|c|c|c|}
\hline \multirow[b]{2}{*}{ Item } & \multicolumn{2}{|r|}{$\mathbf{N}$} & & \multirow{2}{*}{\multicolumn{2}{|c|}{ SD }} \\
\hline & Valid & Missing & Mean & & \\
\hline Q23 prepared for work & & 136 & 5 & 3.16 & 0.60 \\
\hline Q24 experience influen. & & 138 & 3 & 2.67 & 0.88 \\
\hline Q25 chancellor involv. & & 106 & 35 & 2.56 & 0.69 \\
\hline Q26 purpose defined & & 123 & 18 & 3.07 & 0.67 \\
\hline Q27 better marketing & . & 120 & 21 & 388 & 0.69 \\
\hline Q28 improve curricula & & 114 & 27 & 2.45 & 0.72 \\
\hline
\end{tabular}

The mean for donors was 2.95 while that for nondonors was 2.93 as shown in Table 16 and in Figure 1.

Table 16

Descriptive Statistics for the Black Alumini Survey, by Donor Status

\begin{tabular}{lrrr}
\hline Donor status & \multicolumn{1}{l}{$\mathbf{N}$} & \multicolumn{1}{l}{ Mean } & \multicolumn{1}{l}{ SD } \\
\hline Donor & 57 & 2.95 & 0.30 \\
Nondonor & 84 & 2.93 & 0.27 \\
Total & 141 & 2.94 & 0.28 \\
\hline
\end{tabular}


Figure 17

Means for the Black Alumni Survey, by Donor Status

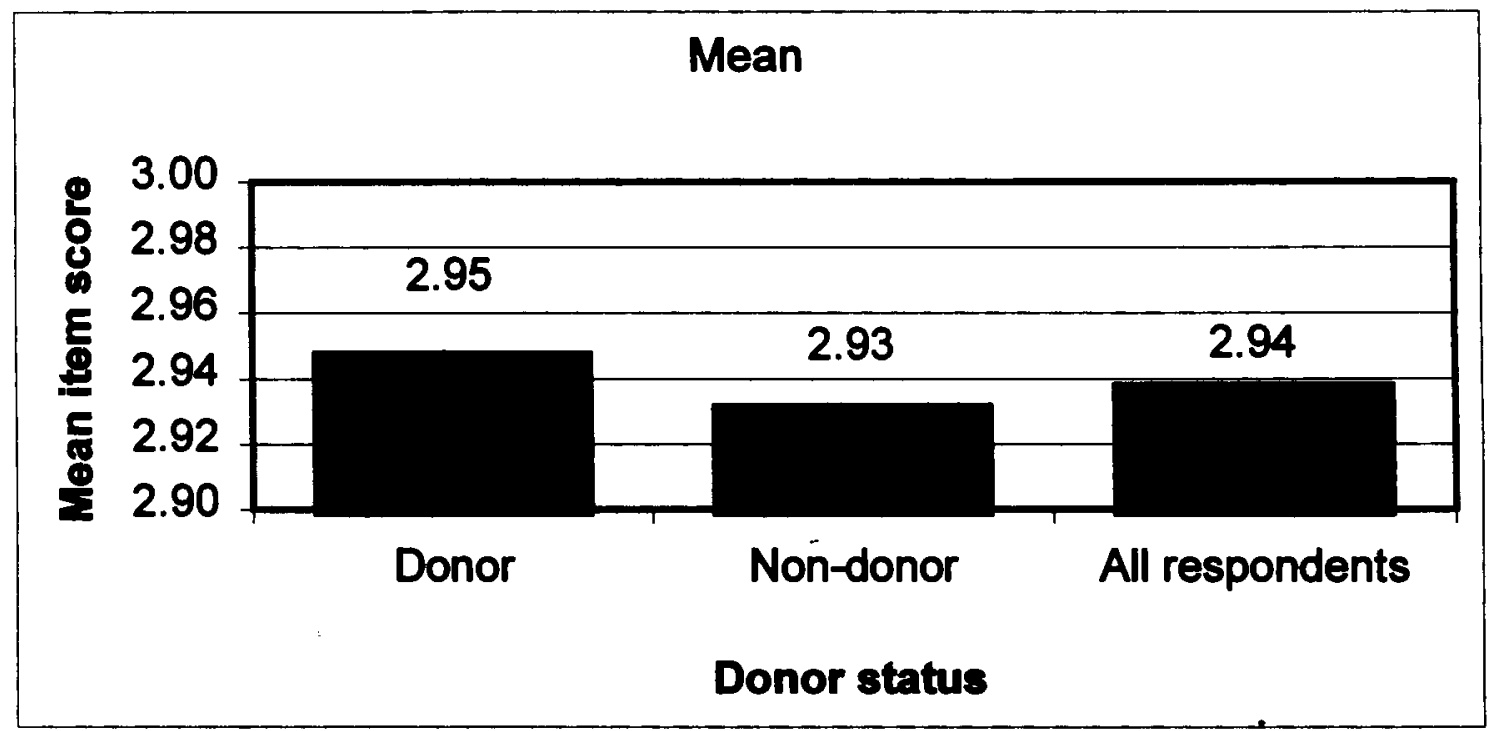

Table 17

ANOVA results for the Black Alumni Survey

\begin{tabular}{lrrrr}
\hline & \multicolumn{1}{l}{ SS } & $\underline{\text { DF }}$ & $\underline{\text { MS }}$ & $\underline{\underline{F}}$ \\
\hline Between & .008 & 1 & .009 & 0.108 \\
Within & 10.961 & 138 & .079 & \\
Total & 10.969 & 139 & & \\
\hline${ }^{\mathrm{P}<.05}$ & & & &
\end{tabular}

\section{Summary}

As indicated in Table 17, there is no statistically significant difference in the Black Alumni Survey's mean score between donors and nondonors, alpha=.05; the null hypothesis is retained. Eta ${ }^{2}$ for this model is .000 (e.g., this model explains 08 of the variance in the dependent variable). In Chapter 5 the 
findings of the study will be discussed and recommendations will

be made for future research. 
CHAPTER $\mathrm{V}$

\section{Summary and Conclusions}

Introduction

This study sought to determine if the attitudes of Black alumni toward the University of Missouri-Columbia influenced their willingness to donate to the school. The data obtained through the Black Alumni Survey was tested using ANOVA and crosstabs with chi-square tests. No statistically significant difference was found between donors and nondonors. Consequently the null hypothesis was accepted.

\section{Overview of Selected Related Research}

Research on the attitudes of Black graduates of predominantly. White large public universities towards their schools and whether their donorship is affected by these attitudes is rare. Iarry Smith's 1987 study of Bowling Green State University, A Predominantly white Public University's Environment and Its Relationship to Giving from Black and White Alumni, is an exception. There is no substantial body of research on the topic of the attitudes of Black alumni of large predominantly white public universities toward their schools as reflected in donorship, that gan serve, as an intellectual touchstone for those interrested in this,topic. Other research on 
alumni donorship, while certainly helpful in many respects--since it is indicative of what was found in studying somewhat similar populations in almost comparable situations--may not prove definitive when applied to another population in a different institution. As Dahl wrote in 1981, much of what causes giving may still be unexplained. In an article which examined the possible consequences repeal of the estate tax might have on gifts to academic institutions, Hebel (2001, p. A23) reported, "College officials. . . say they are crafting their positions largely based on what they describe as gut feelings on what motivates people to give."

Additionally, even though there are some fairly widely held beliefs regarding donors, various studies have yielded contradictory as well as supportive results when researching the same variable with different populations at dissimilar institutions. For example, okunade found that male graduate alumni were more likely to donate than were female alumni (1996). Orlans (1997) found that women were responsible for only 338 of the donations at UCLA and 368 of the donations at the University of Wisconsin. From January through December 1998, the University of Missouri-Columbia's Development office reported that 16,143 male alumni donated compared to 10,446 females (K. Ming, E-mail, February 4, 1999). Parsons and Wethington (1996), on the other hand, found, "Women are slightly more likely to give, and this likelihood increases by income level." In a 1992 article in the New York Times titled, "As for That Myth About How Much Alumnae 
Give," Butterfield reported that the Council for Aid to Education "ranked Wellesley first in the country in giving as measured by the number of students attending a college, with alumnae gifts of $\$ 10,373$ per enrolled student." The article noted the great generosity alumni of women's colleges showed their schools, and went on to state that even relative to coeducational institutions, women were beginning to give at a rate closer to that of their male counterparts. Okunade, Wunnava, and Walsh (1994) found that women were more likely to give to charities other than schools, however. Further, Beeler (1982) found that alumni who lived at a greater distance from their alma mater were more likely to donate while McKee (1975) noted the opposite. Oglesby (1991) and Haddad (1986) did not find a significant relationship between distance from the school and alumni donorship. Cockriel (1983), Enyard (1993), and Beeler (1982) found a relationship between receipt of financial aid or other monetary assistance while students and the willingness of individuals to donate as alumi. Neither Haddad (1986) nor Oglesby (1991) found this to be a significant factor though. Ninety-one women participated in this investigation of Black alumni attitudes toward the University of Missouri-Columbia in contrast to 50 men. This study included alumni of the school from 1950 through 1995. By 1995, there were 1,934 Black graduates of the university. Of that number 1,077 were females while 857 were males. In contrast there were 86,194 males of the 151,386 non-Black graduates of the university with females 
comprising 65,192 of that group. Forty-three percent of the nonBlack alumni were female and $57 \%$ were male. On the other hand, 568 of the Black alumi of the university were female and 448 were male.

of the 335 alumni randanly chosen to receive the questionnaire, $132(398)$ were male and 203 (61:) were female. That 50 (35\%) of the respondents were male while 91 (65\%) of the respondents were females did not seem overly remarkable given the gender proportions of the instrument's recipients. Caryn Shoemaker (1991) found that females were more likely to respond to her study. J. H. Evans' (1986) study of Black alumni of historically Black colleges had 227 female in comparison to 95 male respondents. Bennett College, a historically female college in North Carolina was represented strongly in that sample. If there is a tendency for females to be a little more likely to respond to surveys than their male counterparts, this may explain the slight differential in female respondents beyond their representation in the sample for my study.

That there were 1,077 females in the population for my study compared to 857 males may be due, at least in part, to the fact that for several decades Black females have been more likely to avail themselves of higher education than Black males (Annual Status Report, Minorities in Higher Education, 1998, p.89). In 1995 at the University of Missouri-Columbia, 68 of the Black male alumni were donors and 68 of the Black female alumni were donors. The average gift for non-Black donors in 1995 was \$506. The 
average gift for Black donors in that year was $\$ 143$. The average gift from a non-Black male during that year was $\$ 639$. The average gift from a non-Black female was $\$ 322$. The average gift for a Black male during that time was $\$ 157$. The average gift for a Black female during that time was $\$ 129$ (Office of Development, 1995). A difference in the level of average gifts is probably due to differences in accumulated wealth and income. There is just a very slight gender difference in donorship rate for Black alumni of the University of Missouri.

Crosstabs with chi-square tests showed that for questions 15 and 18 of the Black Alumni Survey there was significance at the .05\% level of confidence for gender and donorship as presented in Tables 11 and 12 . Question 15 delved into the affect quanity and quality of university correspondence had on donorship. This mattered to nondonor males. Nondonor females did not find this of importance. It would seem then that males might be swayed by information sent to them by the university while females indicated that this was not of consequence to them. For question 18, which dealt with the performance of the alumni association, there was a difference in the views of donor males and females. The crosstabs showed that this was of concern to donor males while it did not concern donor females.

The 568 donorship rate for those earning $\$ 50,000$ per year or more was so striking that an additional statistical test was conducted. One-way ANOVA was performed on income level data for responses to the attitudinal test. Significance was found for 
questions 12 and 14 . Question 12 stated "I an kept informed about Mizzou's programs and services." "Written communication from Mizzou are clear and Informative," was the text of question 14. These were Ilkert scales with responses strongly disagree, disagree, agree, and strongly disagree. One-way ANOVA showed that the responses tended to go from agree:to disagree with increased incone. That donorship seemed to increase with income despite the fact that individuals were less Iikely to find that they were being kept well informed or that written commurication was clear and informative, would indicate that these "failings" were not decisive ones for them. That alumi who earn higher incomes are more likely to be dothors is a belief of development and supported by a number of researchers (Bruggink \&iddiqui, 1995; Haddad, 1986; Miracle, 1977).

By 1998, Black donorship overall had risen to 108 at the University of Missouri-Columbia." In 2000, Bleck donorship:" doubled over the 1998 level to 208 (K. Ming, University of Missouri-Columbia, Office of Development office, E-mall, March 28, 2000). This is attributed to the campaign associated with the new Black Culture Center (I. Scott, President, BIack Alumni Organization, personal communication, March 28, 2000).

It is interesting that the 15 individuals who each heId several degrees from the university were almost evenly divided between donors and nondonors. Seven (478) were donors while 8 were nondonors. : 
The variables that researchers have examined in attempting to explain alumni donorship differ. These variables include, for example, receiving financial aid (Beeler, 1982; Enyard, 1993; Shadoian; 1989), number and age of children (Beeler, 1992; Haddad, 1986), and involvement in alumni activities (Haddad, 1986). A number of those who have researched alumni donorship have, in some ways, investigated the same variables examined in this study: the leadership, image, and management of the school conjoined with the quality of education, view of the alumni association, student experiences, preparation for work, age, income, marital 'status, and residence (Beeler, 1982; J. H. Evans, 1986; Haddad, 1986, Oglesby, 1991).

An examination of Black as contrasted with non-Black donorship at the University of Missouri-Columbia by decades beginning with the 1950 s reveals somewhat surprising patterns. The donorship rate for Black alumni who graduated curing the $1950 \mathrm{~s}$ is 2.48 higher than that for non-Black alumni for the same decade. The donorship rate for Blacks who graduated during the 1960 s is 7.78 higher than for non-Blacks who attended during that period. Non-Blacks who graduated during the 1970s, however, have a donorship rate that is 11.38 higher than that of Blacks who attended the university during that decade. Non-Blacks who attended during the $1980 \mathrm{~s}$ have a donorship rate 10.78 higher than that for Blacks who attended during that decade. Blacks who attended the university during the 1990 s have a 6.28 lower 
donorship rate than that for non-Blacks who attended the university during the 1990s.

There are only 13 Black alumi from the 1950s. The 1960s produced 77 Black alumni. It is possible that these small numbers may have caused some form of group cohesiveness or identity that translated into what appears to be loyalty to the university since it was the focal point of their interactions. Researchers have found that for a soliciting organization to be successful potential donors must be able to identify with it and the purpose for which it is asking gifts (Haggberg, 1992; Hartsook, 1998; Mai, 1991; Squires, 1997). Furthermore, these were the first Black students to venture into a university that had fought for many years to remain segregated. They were pioneers. There may be something somewhat unique about these individuals as alumni, inherently or due to their experiences. To dismiss the high rate of 1950 s and 1960 s Black donorship as reflective of the tendency of older graduates to be more likely to give to their alma mater (Bruggink siddiqui, 1995; Haddad, 1986; Miracle, 1977) ignores the fact that the percentage of donorship by non-Blacks lags behind that of their Black counterparts. Although certainly overall, for both groups, as would be predicted, the rate of donorship for $1950 \mathrm{~s}$ and $1960 \mathrm{~s}$ graduates was higher than for graduates of the other three decades. A number of factors could be at play here. Certain events or personalities that the Black students of those decades encountered may have left a strong impression on them. Non-Black 
graduates of the period may have issues that resulted in their lower rate of donorship.

Black alumni of the last three decades have donated at a lower rate than have non-Black graduates of those years. Hundreds of Blacks graduated in the 1970s, 1980s, and 1990s. Perhaps these numbers were too large to engender a strong sense of camaraderie in Black students. Other factors may have influenced these lower rates of donorship as well. Black graduates of the 1970 s have donated at the rate of 40.98 , those of the $1980 \mathrm{~s}$ at 31.78 , and those of the $1990 \mathrm{~s}$ at 12.78 . The Council for Aid to Education reported in 1998 that public research/doctoral institutions had an alumni solicitation effectiveness of 17.68 . In light of this data, the donorship rates for Black Alumi of the 1970 s and 1980 s are respectable and show the expected increase in donorship for those with more distant dates of graduation (Bruggink \& Siddiqui, 1995; Haddad, 1986; Miracle, 1977). Nevertheless that Black graduates of the 1970 s are 11.38 less likely to be donors than non-Blacks who graduated during that period while those of the $1980 \mathrm{~s}$ are $10.7 \%$ less likely to be donors than other graduates of that era and those of the 1990s are only 6.28 less likely to be donors than are their peers is interesting. The generosity of 1990 s Black graduates compared to Black alumni of the 1970 s and 1980 s may be another manifestation of the tendency for recent graduates to donate to their schools (Marcus, 2000, p. 54). Additionally, some of the graduates of this time were recipients of the 
university's largess as it attempted to attract Black students in the early 1990s (J. Craig, Office of Vice-Provost for Minority Affairs and Faculty Development, personal communication, April 3, 2000). Cockriel (1983), Enyard (1993), and Beeler (1982) found that those who were recipients of scholarships and other financial assistance were more likely to be donors. 
Table 18

Donorship of Black and Non-Black Alumni, By Decades

\begin{tabular}{|c|c|c|c|c|c|c|c|c|}
\hline & & & & & Non & Non & & \\
\hline & & Black & Black & Non & Black & Black & 8 & 8 Non \\
\hline & Black & Male & Fem. & Black & Male & Fem. & Black & Black \\
\hline Deca. & Grad. & Don. & Don. & Grad. & Don. & Don. & Don. & Don. \\
\hline $1950 \mathrm{~s}$ & 13 & 5 & 4 & 12438 & 6058 & 2254 & 69.28 & 66.88 \\
\hline $1960 \mathrm{~s}$ & 77 & 28 & 26 & 20636 & 8305 & 4578 & 70.18 & 62.48 \\
\hline $1970 \mathrm{~s}$ & 301 & 60 & 63 & 38544 & 11791 & 8312 & 40.98 & 52.28 \\
\hline $1980 \mathrm{~s}$ & 603 & 81 & 110 & 39967 & 8686 & 8276 & 31.78 & 42.48 \\
\hline $1990 \mathrm{~s}$ & 1393 & 79 & 98 & 39767 & 3599 & 3901 & 12.78 & 18.98 \\
\hline
\end{tabular}

A comparison of Black and non-Black donors by selected school or college also showed distinctive patterns. Non-Blacks with degrees in business had a donorship rate 16.98 higher than Blacks who attended the program. College of Education alumni who are Black had an 8.18 lower rate of donorship than their nonBlack counterparts. Black engineering alumni had an 88 lower rate of donorship than non-Black alumni did. Non-Blacks with degrees in journalism had a 24.68 higher rate of donorship than Blacks who attended that program. Blacks with degrees from the School of Law were 28.18 less likely to donate than non-Blacks who attended that school. Non-Black school of Medicine graduates donated at a rate that was 25.48 higher than that for Black graduates of that college. Nursing graduates who are Black have 
been 6.78 less likely to donate than non-Black-nursing alumni have.

Some of the programs that graduate individuals who, normally, may expect relatively high incomes, namely medicine and law, had among the highest rates of difference between contributions from Black and non-Black alumni. Other programs had much smaller, although certainly notable differences, in the rate of Black and non-Black alumni donorship. Law, medicine, journalism, and nursing had the highest percentages of donorship from non-Black alumni while nursing, law, education, and engineering had the highest percentages of donorship from Black graduates. Comparatively, the schools with the lowest donorship rates for non-Black graduates were engineering, education, and business. Programs with the lowest rate of Black donorship were medicine, journalism and business.

In 2000, slightly over 398 of all alumni were contributors while a little over 208 of all Black alumi had become donors ( $\mathrm{K}$. Ming, University of Missouri-Columbia, Office of Development, Email, March 28, 2000). Compared to the average number of alumni donors for the university as a whole, the rate of donorship for White and Black graduates of the schools and colleges selected for this analysis is high. In view of these findings, a more extensive comparison of various programs, colleges, and schools in terms their alumni donorship might be worthwhile. 
Table 19

Donorship of Black \& Non-Black Alumni, By College or School

\begin{tabular}{|c|c|c|c|c|c|c|c|c|}
\hline \multirow[b]{4}{*}{ Schl. } & \multirow{4}{*}{$\begin{array}{l}\text { Black } \\
\text { Grad. }\end{array}$} & \multirow{3}{*}{$\begin{array}{l}\text { Black } \\
\text { Male }\end{array}$} & \multirow{3}{*}{$\begin{array}{l}\text { Black } \\
\text { Eem. }\end{array}$} & \multirow{3}{*}{$\begin{array}{l}\text { Non } \\
\text { Black }\end{array}$} & \multirow{2}{*}{$\begin{array}{l}\text { Non } \\
\text { Black }\end{array}$} & \multicolumn{2}{|l|}{ Non } & \multirow[b]{2}{*}{ \& Non } \\
\hline & & & & & & Black & 8 & \\
\hline & & & & & Male & Fem. & Black & Black \\
\hline & & Don. & Don. & Grad. & Don. & Don. & Don. & Don \\
\hline Bus. & 117 & 22 & 22 & 16366 & 7092 & 1829 & 37.68 & 54.58 \\
\hline Edu. & 223 & 48 & 45 & 26111 & 4122 & 8889 & 41.78 & $49.8 \%$ \\
\hline Engn. & 50 & 15 & 4 & 11446 & 4930 & 335 & 38.08 & 46.08 \\
\hline Jour. & 145 & 18 & 35 & 9807 & 3260 & 2737 & 36.68 & 61.28 \\
\hline Law & 65 & 18 & 14 & 3445 & 2261 & 403 & 49.28 & 77.38 \\
\hline Med. & 44 & 11 & 5 & 3416 & 1764 & 347 & 36.48 & 61.88 \\
\hline Nurs. & 35 & 0 & 19 & 2523 & 47 & 1492 & 54.38 & 61.08 \\
\hline
\end{tabular}

Table 20, excerpted from Table 252, "Earnings by Highest Degree Earned: 1999" in the Statistical Abstract of the United States: 2000,2000, p. 158, shows considerable discrepancies in income when race and/or gender are factored into the equation. It may not be a great surprise that a Black woman with a bachelor's degree, on average, earned $\$ 1,089$ less than a white man with some college or $\$ 9,159$ less than a white man with an associate's degree or even $\$ 24,668$ less than a white man with her same level of credential.

Normally though across the categories advanced degrees indicate salary increases for individuals whether white or Black, 
male or female. It should be noted, however, that those holding professional degrees are usually better compensated, monetarily, than those holding doctorates. Nevertheless, Black men seem to be the only group, of those, in this analysis, actually penalized for aspiring to a higher level of credential. A Black man with a master's degree could have expected to earn $\$ 47,951$, on average, in 1999. A Black man with a Ph.D., on the other hand, could only expect to earn $\$ 46,743$ that year. This is a difference of over $\$ 1,200$.

Differences can certainly be explained in terms of racial/gender concentrations in fields with varying levels of compensation and other factors such as length of time in a position or career. Nevertheless an analysis of these discrepancies still point to inequities, both historical and contemporary, ranging from schools and homes that do not adequately prepare Blacks or females for higher paying fields to discriminatory employment practices. 
Table 20

Earnings by Highest Degree Held for Blacks \& Whites, by Gender

\begin{tabular}{lllllll}
\hline & Some & Asst.'s & Bach.'s & & & \\
Chart. & College & Degree & Degree & Masters & Profss. & Doctor. \\
\hline All & 25,686 & 32,468 & 43,782 & 52,794 & 95,488 & 74,712 \\
Persons & & & & & & \\
White & 26,357 & 33,212 & 44,852 & 53,497 & 99,858 & 77,970 \\
Male & 33,041 & 41,111 & 56,620 & 65,637 & 112,944 & 85,837 \\
Female & 19,390 & 25,679 & 31,406 & 40,679 & 67,998 & 55,793 \\
Black & 22,148 & 26,424 & 36,373 & 43,054 & 53,969 & 46,848 \\
Male & 25,807 & 29,532 & 42,539 & 47,951 & 68,693 & 46,743 \\
Female & 19,269 & 24,187 & 31,952 & 39,760 & 39,109 & 46,914 \\
\hline
\end{tabular}

Review of Black Alumni Survey Data

Questions 1 through 5 of the Black Alumni Survey dealt with the chancellor. Questions 1 through 4 asked the participants to assess the skills and abilities of the chancellor. On average, most of the respondents indicated for each of these questions a positive assessment of the chancellor. However, for each of these questions, about half of the participants did not provide an answer. Additionally, a small number indicated that they felt that the chancellor had not performed well. For question five, "My impression of the chancellor influences my giving," only 27 of the 141 participants in the study agreed, 71 dissented, and 43 failed to respond. The respondents generally did not believe that 
this official influenced their donorship. Several factors may be important to the way in which study participants dealt with these questions.

For many of the participants, there may have been not only a lack of knowledge about the chancellor but possibly a lack of interest in that university official. Almost half of the sample failed to respond to questions concerning the competencies of the chancellor. J. H. Evans (1986), Pearson (1996), and other researchers probed alumni assessment of the leadership of the schools they were researching with meaningful results. Evans investigated six small historically Black schools located in the South. Although Pearson's study involved the University of Virginia, it focused on the Curry school of Education of that institution. The leadership of the Curry School was what his respondents were asked to assess. In the case of Pearson's sample, it is reasonable to assume that they would be able to evaluate the leadership of the school within the University of Virginia that they had attended. Each of the institutions that Evans studied was relatively small. Leadership on these campuses would likely play a critical role in the life of each institution and no doubt students and interested alumni would be quite aware of that. It is possible that at a school as large as the University of Missouri-Columbia, contact with the head of the institution is limited.

The questions on the public image of the university fared quite differently than did those on leadership. Overwhelmingly, 
alumni indicated that they felt that the school was nationally respected, attracted good students, was well managed, competitive, and treated positively in the media. This positive assessment of the school, however, according to the respondents, did not influence their giving. It is interesting that other researchers have found that regardless of donor status, alumni usually feel positively toward their school in terms of its prestige and image (Chewning, 1984; Littrell, 1989; Oglesby, 1991; Pearson, 1996; L. J. Smith, 1998). Positive views of the school's academic prowess despite other feelings toward the institution may be due in part to the fact that the school. was chosen by the alumni.

Most alumni felt that the school communicated with them frequently, keeping them informed about the campus and the activities of the institution. Nevertheless, respondents indicated that this did not influence their giving. J. H. Evans (1986) found a relationship between donorship and university correspondence with alumni. Littrell (1989), on the other hand, did not find a significant relationship between correspondence and donorship. Relevant to the University of Missouri, it may well be that, in general, the Black alumni were not interested in the things being communicated to them by the school.

Overall, alumni felt that the Alumni Association was managed well and kept in frequent contact with them. However, this did not influence alumni giving according to the respondents. Evans (1986) found a significant relationship 
between alumni perception of alumni association effectiveness and their willingness to donate. The schools Evans studied are all relatively small. Many of the alumni of such schools would probably know or know of practically all of those who attended the institution at the same time that they did. Moreover, they would have known or been familiar with most of the faculty and many of the staff. At the University of Missouri-Columbia, on the other hand, numerous articles in the campus newspaper are about individuals associated with the school that many of those currently on campus probably do not know personally or are even really aware of. This problem is compounded for those who, are no longer associated with the school on a day-to-day basis. The sheer size of the university compared with the small schools of which Evans wrote, coupled with the fact that the university is predominantly a majority race campus, makes for a degree of impersonality for the Black alumni that might mitigate against the importance of alumni association correspondence.

One hundred twenty-nine (91\%) alumni felt that their academic experiences at the university had been sound. Eight disagreed and four alumni did not answer the question. Eighty alumni felt that the extracurricular activities of the campus enhanced their education. Sixty alumni did not agree and one did not respond to the question. Sixty of the alumni found campus life outside the classroom rewarding. One hundred (71\%) alumni felt that their teachers had been genuinely interested in their education. Thirty-six disagreed and five alumni did not answer 
the question. Overall, 112 (79\%) alumni found their experiences at the university positive with only 26 disagreeing and 3 failing to respond. Furthermore, these alumni felt that their education had prepared them for their careers. Eighty (57\%) former students felt that their educational experiences did influence their willingness to give to the university. Fifty-eight disagreed and three people did not answer the question. A majority of donors and nondonors believed that their student experiences influenced their willingness to donate to the school. Both donors and nondonor responses to the questions in this section indicate a strong endorsement and approval of their overall experiences at the university.

One hundred and two alumni (72\%) agreed that the "purpose of fund raising should be more clearly defined." Twenty-one disagreed and 18 did not answer the question. The alumni also indicated very strongly, 100 or $71 \%$, that they felt that the university needed a better marketing program. Black alumni, it would seem from these numbers, did not feel that the university has demonstrated a need for alumni solicitation or indicated how, satisfactorily, it would use the revenues generated. Possibly, too, this may indicate that the needs for which monies have been solicited were not of particular interest to this sample. Tromble (1998) wrote, "the donor wants to know quickly and clearly what the problem is, and furthermore what will fix it." Currently 20 of of Black alumni are donors. This seems to be linked to a campaign associated with the university's new Black 
Culture Center. This may have been a meaningful enough effort for Black alumni to double their 1998 donorship rate and almost triple the donorship rate for the first five years of the 1990 s. Fifty-two (37\%) of the respondents believed that their contributions would improve the curriculum; 62 (44\%) disagreed and 27 (198) did not answer the question. The majority of the sample felt that their contribution would have little impact on the academic performance of the institution.

It is interesting that with only $6 \%$ donorship on the part of Black male alumni and $6 \%$ donorship on the part of Black female alumni when this study was conducted, $40 \%$ of the sample were donors. In several studies, donors have proven more likely to be respondents than nondonors have (Burgess-Getts, 1992; Oglesby, 1991, L. J. Smith, 1998; L. T. Smith, 1987). If respondents are somewhat more likely to be donors it may indicate a greater tendency on the part of donors to be cooperative. This may also show slight reluctance on the part of many nondonors to participate in an activity that they may conceivably view as somewhat critical of them rather than as an opportunity "to vent their spleen." That a large number of the respondents to the Black Alumni Survey were donors far in excess of their representation in the population may indicate a subset of the population that is either actually more kindly disposed toward the institution than others or more disposed to be cooperative generally. 
It is interesting to note that $46 \%$ of the male respondents were donors compared to $37 \%$ of the female respondents. Even with substantially more female representation in the sample, the percentage of male respondents who were donors exceeded the number of female respondents who were donors by 9\%. Twenty-six percent of female donors lived in Missouri; $24 \%$ of male donors lived within the state. Eleven percent of female donors lived outside of Missouri while $22 \%$ of male donors resided beyond the state's boundaries. Thirty-six percent of female nondonors lived in state while $20 \%$ of male nondonors were Missourians. Thirtyfour percent of male nondonors were not Missouri residents while 26\% of female nondonors lived outside the boundaries of the state. Oglesby (1991) and Haddad (1986) did not find a relationship between distance of residence from the campus and donor status. Beeler (1982), however, did. In the case of MU, donors and nondonors seemed about equally in evidence among residents of Missouri and those who lived outside of the state. These figures do show a slightly greater tendency for Black female alumni in this sample to remain within Missouri than their male counterparts.

Thirty-three percent of the respondents who earned a bachelor's degree from the university were donors compared to a $24 \%$ donor rate for those who had earned their graduate degree at the school. Thirty-two percent of those who held a bachelor's degree as their highest degree earned from any institution were donors. Forty-four percent of those who held a graduate degree 
as their highest degree earned from any institution were donors. It appears that those who received their bachelor degrees from the university were somewhat more likely to donate to the school. On the other hand, those who held a graduate degree as their highest degree were more likely to donate than were those who held a bachelor's as their highest degree. Researchers have arrived at contradictory findings in relation to the importance of degrees held and where they were earned. Beeler (1982) did not find any significant relationship between degree held and donorship. Miracle (1977) found that those who earned an undergraduate degree at a school were more likely to be donors than those who earned a graduate degree at the same institution. McKee (1975) found that donors were likely to be those who earned several degrees at a school.

Older, married alumni who earned higher incomes were more likely to be donors than younger, single, less affluent ones. This seems to be the conventional wisdom of development and supported by a number of researchers (Bruggink \& Siddiqui, 1995; Haddad, 1986; Miracle, 1977). Interestingly, however, recent college and university graduates have been unusually generous to their schools (Marcus, 2000, p. 54).

\section{Discussion}

The focus of this research was whether or not attitudes affected donorship. There were six categories of questions in the Black Alumni Survey. Five of these categories had a final 
question to determine if the views expressed in the preceding questions in that category had any influence on the willingness of the respondent to donate to the university.

In all but one instance, respondents indicated that their perception of the institution in relation to the performances discussed did not influence their donorship. However, in the instance of student experience, 80 (57\%) of the respondents indicated that their experiences influenced their willingness to donate to the institution. Correcting for the 3 participants who did not answer the question, $58 \%$ of the respondents felt that their experiences as students affected their willingness to donate. Sixty-four percent of the donors took this position and $54 \%$ of the nondonors agreed. Donors and nondonors were fairly united in the view that their educational experience affected their donorship. Furthermore, it should be kept in mind that because a person had not donated as of the time that they participated in the Black Alumni Survey did not mean that they had the intention of never donating. No item in the survey probed the question of donorship intent. Some of the nondonors may very well not have been totally averse to donating in the future, perhaps when their finances allowed and some project that captured their enthusiasm was presented.

In her 1986 study, Dr. Evans found a relationship between donorship and alumni attitudes toward their institutions in each of five categories examined by her questionnaire:

- Leadership of the school 
- Image of the school

- Frequency and clarity of correspondence from the school

- Alumni relations program of the school

- Student and alumni experiences related to the school

At first glance, my findings appear startlingly different from those of my predecessor in Black alumni attitude research. However, even though I used a slightly modified form of Evans' questionnaire to research Black alumni attitudes toward their alma mater, there are both subtle and obvious differences in our research.

Dr. Evans postulated a null hypothesis for each attitudinal category in her survey which stated that there was no relationship between it and alumni giving. For example, one null hypothesis read: "There is no relationship between the experiences of alumni as undergraduate students and alumni giving." On the other hand, I sought to discern not just if attitudes affected donorship but whether there was a difference between donors and nondonors in this respect. My null hypothesis was:

H0: There is no statistically significant difference in the Black Alumni Survey's mean item score between donors and nondonors, Alpha=.05.

Dr. Evans sought to determine if attitudes affected giving. I wanted to determine if there was a significant difference in attitudes toward the school between donors and nondonors. She 
used the Kolmogorov-Smirnov $(\mathrm{K}-\mathrm{S})$ one sample test to treat her data. A test of the degree of agreement between observed and hypothesized probability distribution, K-S is comparable to chisquare (Evans, 1986, p. 28). Evans sought to determine if attitudes affected alumni willingness to donate. My research sought to discern whether there was a difference between donor and nondonor attitudes toward the institution. ANOVA is used to compare the mean scores of two or more groups (Stockburger, 1996). Comparing donors and nondonors attitudes was the focus of my study rather than simply determining whether attitudes affect donorship. Therefore ANOVA was a suitable statistical test for my research.

My study showed no significant difference attitudinally between alumni donors and nondonors toward the university as reported using the Black Alumni Survey. Whether or not attitudes are strong correlates of behavior is something that those who research human behavior have not determined finally. Some researchers have not found that attitudes cause behaviors (Boldero, 1995; Jaccard, Helbig, Wan, Gutman, \& KritzSilverstein, 1990; Manfredo, Yuan, \& McGuire, 1992). Other researchers have presented studies supporting the view that behavior follows attitudes (Bagozzi, 1981; Finlay, Trafimow, \& Jones, 1997; Fishbein, 1967; Maoi \& Olson, 1995; Morrison, Gillmore, Simpson, Wells, \& Hoppe, 1996). Certain researchers have conducted studies that have shown that behavior can be changed by changing attitudes (Badovinac, 1994; Beach, 1984; 
Castle, 1952; Chapman, Ham, Liesen, \& Winter, 1995; "Drink Drive Campaign," 1997; Flowers, Miller, Smith, \& Booraem, 1994; Hemsworth, Coleman, \& Barnett, 1994; Kempf, 1935).

The question of how attitudes and behavior relate is still unresolved. Nevertheless, it seems that a great deal of human conduct, ranging from the social to the economic, hinges on the assumption that affecting attitudes, whether it be regarded as persuasion of something akin, will result in certain behaviors. Science of course has as one of its roles, the testing of these cherished social assumptions. Still, it is somewhat disconcerting for this study to find no significant difference in the attitudes of donors and nondonors, and further, to have respondents answer in the negative to all but one of the five questions designed to gauge a relationship between attitudes and donorship. Evans found a relationship between attitudes and donorship in her study. There might be a number of reasons why with essentially the same instrument, Dr. Evans' respondents indicated that their attitudes influenced their willingness to donate where my respondents, in general, with the exception of question 24--"The quality of my educational experiences has a significant influence on my annual giving"--indicated that their attitudes did not influence their donorship.

One of the reasons why my respondents did not feel that their attitudes measured by four of the questions asked influenced their giving might be that these questions were on 
subjects that were not critically important to them. The four questions were:

5. My impression of the chancellor has significant influence on my financial giving.

11. The perceived public image of Mizzou has a significant Influence on my financial giving.

15. The frequency and clarity of the correspondence from Mizzou has significant influence on my financial giving.

18. The quality of the Alumni Association of Mizzou has significant influence on my financial giving.

Dr. Evans initially designed her instrument to be used to query the alumni of six historically Black colleges and universities: Elizabeth City State University, Morgan State University, Virginia State University, Bennett College, Saint Paul's College, and Shaw University. Small historically Black colleges and universities are unique institutions. Many of the schools in this category have existed for years in a state of ongoing financial exigency. Despite somewhat limited economic resources, these schools have had a relationship with their students of which Dr. Shirley A. R. Lewis wrote in 1992 (pp. 7273): "Students enrolled in HBCU express high enthusiasm for their on-campus experiences. They laud their colleges for their familylike atmosphere, inspiring (and demanding) teachers, close-knit social structures, strong moral values, solid retention programs, touchable role models. . . ." In institutions such as these, 
the president or chancellor would be very important. The small size of the institution would make this role a more apparent fact of campus life. The chancellor of the University of MissouriColumbia in contrast is not necessarily perceived by individual students as being that critical to their campus experience. The abilities of the head of a historically Black college or university may be paramount to that school's economic health. Certainly, the chancellor of the University of Missouri-Columbia is important in the economic life of the university. However the individual in this position is probably not critical to the fiscal viability of the institution. The public image of the school, its correspondence with alumni, and its alumni association may also be more critical factors in the attitudes that alumni of small, more familial, and more fiscally challenged institutions have toward their school as compared with a school such as the University of Missouri-Columbia.

To perform well in terms of having a good public image, keeping alumni apprised through correspondence, and possessing a sound alumni program might well be triumphs for small, struggling schools that oftentimes have existed in hostile social climates. Being able to accomplish these same tasks well is something that could be taken for granted by a large, prestigious, affluent, land grand institution. Being perceived to perform these tasks well may be the difference for some historically Black schools between viability and dissolution. No doubt alumni are well aware of this connection for these institutions. A school which 
is seen as floundering might prove a discouragement to alumni donorship. An extremely wealthy benefactor could help. Inspired fund raising might also salvage the institution. However, average alumni might be reluctant to donate what large sums of money that they could afford for fear that it might be to no avail. The University of Missouri-Columbia may find that its ability to accomplish certain goals may be impended by lack of alumni support. However, alumni support through solicitation is not central to its existence. Historically Black schools may be judged by alumni as worthy of support in terms of their leadership, image, correspondence with alumni, alumni programs, and treatment of students. Alumni support of a school that does not rely on solicitation for critical support may very well depend more on how the money will be spent than on general evaluations of the school's leadership and functions. The individual schools, colleges, or programs from which they graduated may be more central to the shaping of alumni attitudes at large universities than the role of a central administration that may be viewed as almost remote.

This was a good test of the Black Alumni Survey. It proved a strong instrument for $\mathrm{Dr}$. Evans and might perform equally well at other small HBCU and, perhaps, at such specialized institutions as women's colleges and church schools. Black alumni of the University of Missouri-Columbia however as indicated by this research may have different issues that form their relationship with the institution. To have tested the 
Black Alumni Survey on this campus is important though. Without doing so assumptions about its suitability for use with the alumni of a school such as the University of Missouri-Columbia would have been conjectural.

If I were to design an instrument, drawing upon my experience with this study and my background as a graduate of this institution, some of the questions that I would ask alumni might include:

- What they think of giving to charity in general.

- Whether they actually donate to other charities.

- What they think of giving to schools in particular.

- Whether or not they actually donate to another academic institution and why (for example, did they obtain a degree from the school to which they donate).

- If they think that a tax supported institution should solicit its alumni.

- If specific projects such as the Black Culture Center would be important to them as potential donors.

- If requests on behalf of faculty who were critical to their development, such as mentors, would spur them to donate.

- If they received financial support from the university while in attendance.

- How satisfied they are with their current status/employment and how critical they believe that 
their attendance at the university was in achieving that status/employment.

- Whether they think that they might ever donate to the university.

- whether they think that their attitudes toward the university overall or in particular would influence their willingness to donate.

- whether they felt that their attitudes toward the university were primarily positive or negative.

- If it would be possible to change their attitude toward the university.

- If they would be willing to donate to the university regardless of their attitude toward it.

Additionally, I would survey the entire Black alumni population rather than a sample. Certainly not all of the alumni would choose to participate but this should nonetheless provide a much larger number of respondents on which to base an analysis. Moreover, I would attempt to interview some of those who failed to respond to the survey instrument. Furthermore, I would incorporate certain elements of qualitative research, such as focus groups and interviews into the research in the hope that these might provide some insight into the alumni not afforded by quantitative efforts. In terms of a research question, I would still focus on attitudes and donorship. 


\section{Limitations}

The findings of this study are specific to the 141 member sample of the Black alumni of the University of Missouri-Columbia who attended the school from 1950 through 1995; no inferences can be made to other populations.

\section{Recommendations}

There are several recommendations for further study. It is recommended that research be conducted to determine if there is a pattern of increase in alumni donorship at institutions at which research into alumni donorship has been conducted.

It is recommended that research be conducted to determine what type of information Black Alumni would like to see as part of fund raising campaigns.

It is recommended that Black alumni be consulted to determine in what ways they would like to see improvement of marketing of the University of Missouri-Columbia for fund raising purposes.

It is recommended that the Black Alumni Survey be further refined to enhance its utility as an assessment instrument.

It is recommended that research be conducted to examine if alumni have determined if they will or will not ever donate to their school and why.

It is recommended that research be conducted to determine why donor patterns differ so considerably among the alumni of the 
University of Missouri-Columbia's various schools, colleges, and programs.

It is recommended that research be conducted to determine why 1950s' and 1960s' Black donors donate at a higher percentage rate than do non-Black donors who graduated during these decades. It recommended that research be undertaken to assess the donorship patterns and attitudes of other groups of minority graduates of the University of Missouri-Columbia. 


\section{REFERENCES}

Abdul-Khabir, T. (1988). Black alumni perceptions of their

experiences at a predominantly white state university, 1967 to 1986 (Doctoral dissertation, University of Akron, 1988). Dissertation Abstracts International, 48, Z5055.

Alan, W. (1986). Gender and campus race differences in Black student academic performance, racial attitudes, and college satisfaction. Atlanta, GA: Southern Education Foundation.

Allen, I. H. (1981). A comparative study of alumni attitudes toward their alma maters at selected small Black church related colleges in Texas (Doctoral dissertation, Kansas State University, 1981). (Dissertation Abstracts International, 42, 25055 .

Allen, W. R. (1987). Black colleges v. White colleges. Change, 19, 28-44.

Allen, W. R., \& Jewell, J. O. (1995). African Americar education since 'an American dilemma.' (An American dilemma revisited). Daedalus, 124, 77-100.

American Association of State Colleges and Universities. (1988). Minorities in public higher education: At a turning point. Lanham, MD: University Publishing Associates, Inc.

American Council on Education. (1985). Minorities in higher education. Washington, DC: Office of Minority Concerns.

Anderson, G. L. (1981). Self-esteem and altruism perceived as motivational factors for alumni giving and their relationships to various donor characteristics (Doctoral dissertation, Western Michigan University, 1981). (Dissertation Abstracts International, 42, Z5055.

Annual status report, Minorities in higher education. (1998). Washington, DC: American Council on Education.

Arbeiter, W. (1987). Black enrollments: The case of the missing student. Change, 19, 14-19.

Atkinson, D. R. (1987). Counseling Blacks: A review of relevant research. Journal of College Student Personnel, 28, 552558 .

Babbie, E. (1986). The practice of social research. Belmont, CA: Wadsworth Publishing Company. 
Babbie, E. (1989). The practice of social research. Belmont, CA: Wadsworth Publishing Company.

Badovinac, K. (1994). The effects of victim impact panels on attitudes and intentions regarding impaired driving. Journal of Alcohol \& Drug Education, 39, 113-118.

Bagozzi, R. P. (1981). Attitudes, intentions, and behavior: A test of some key hypotheses. Journal of Personality and Social Psychology, 41, 607-627.

Baldwin, J. A., Duncan, J. A., \& Bell, Y. (1987). Assessment of African self-consciousness among Black college students from two college environments. Journal of Black Psychology, 1, 27-41.

Baratz, J. S., \& Ficklin, M. (1983). Participation of recent Black college graduates in the labor market and in graduate education. Princeton, NJ: Educational Testing Service.

Beach, R. (1984). Components of composition inservice; Theory, categories, attitudes, and behaviors. English Education, $16,83-93$.

Beeler, K. J. (1982). A study of predictors of alumni philanthropy in private universities (Doctoral dissertation, University of Connecticut, 1982). Dissertation Abstracts International, 43, 25055.

Bendapudi, N., Singh, S. N., \& Bendapudi, V. (1996). Enhancing helping behavior: An integrative framework for promotion planning. Journal of Marketing, 60, 33-49.

Bennett, L. (1962). Before the Mayflower: A history of the Negro in America 1619-1962. Chicago: Johnson Publishing Company.

Bennett, W. J. (1988). Our children and our country. New York: Simon and Schuster.

Billingsley, A. (1981). The case for Black colleges. Essence, 12, 124 .

The Black middle class. (1998). CQ Researcher, 8, pp. 4972 .

Boldero, J. (1995). The prediction of household recycling of newspapers: The role of attitudes, intentions, and situational factors. Journal of Applied Social Psychology, 25, 440-462.

Borg, W. R., \& Gall, M. D. (1983). Educational research an introduction $\left(4^{\text {th }}\right.$ ed.). New York: Longman. 
Both the number and the proportion of Black Americans with high-school and college degrees are increasing, according to survey data released last week by the U.S. Census Bureau. (1996, June 21). Chronicle of Higher Education, 42, A29.

Braddock, J. \& McPartland, J. M. (1988). Some cost benefit considerations for Black college students attending predominantly White versus predominantly Black universities. In Neules, M. T. (Ed.), Toward Black undergraduate student equality in American higher education (pp. 87-104). New York: Greenwood.

Brazziel, W. F. (1988). Road blocks to graduate school: Black Americans are not achieving parity. Educational Record, 68, 108-115.

Brubacher, J. S., \& Willis, R. (1976). Higher education in transition. New York: Harper and Row, Publishers.

Bruggink, T. H., \& Siggiqui, K. (1995). An econometric model of alumni giving: a case study for a liberal arts college. American Economist, 39, 53-60.

Bullock, H. A. (1967). A history of Negro education in the South. New York: Praeger Publishers.

Burgess-Getts, L. F. (1992). Alumni as givers: An analysis of donor nondonor behavior at a comprehensive 1 institution (Doctoral dissertation, College of William and Mary, 1992). Dissertation Abstracts International, 53, Z5055.

Burnett, R. D. (1981). A study of the solicitation of private gifts to South Dakota public institutions of higher education (Doctoral dissertation, University of South Dakota, 1981). Dissertation Abstracts International, 42, 25055.

Butterfield, F. (1992, February 26). As for that myth about how much alumnae give. New York Times, p. B6.

Button, H. W., \& Provenzo, E. F. (1989). History of education and culture in America. Englewood Cliffs, NJ: Prentice Hall.

Bynum, J. E. \& Thompson, W. E. (1983, Fall). Dropouts, stopouts and persisters: The effects of race and sex composition of college classes. College and University, 59, 39-48.

Calvario, D. A. (1996). College experience, satisfaction and intent to financially support one's alma mater (Doctoral dissertation, University of Northern Colorado, 1996). Dissertation Abstracts International, 57, Z5055.

Carnegie Foundation for the Advancement of Teaching. (1987). Minority access: A question of equity. Change, 19, 35-39. 121 
Carson, E. D. (1989, Summer). Black philanthropy: Shaping tomorrow's non-profit sector. NSFRE Journal, 23-31.

48 .

Carter, L. K. (1988). Minority interest. Currents, 14, 46-

Castle, P. F. C. (1952). The evaluation of human relations training for supervisors. Occupational Psychology, 26, 191-205.

Changing U.S. population and the future labor force: Data needs for the $21^{\text {st }}$ century: Hearing before the Subcommittee on Census and Population of the Committee on Post Office and Civil Service, House of Representative, 102d Cong., 1st Sess. 1 (1991).

Chapman, K. M., Ham, J. O., Liesen, P., \& Winter, L. (1995). Applying behavioral models to dietary education of elderly diabetic patients. Journal of Nutrition Education, 27, 75-79.

Cheatham, H. E., Tomlinson, S. M. \& Ward, T. J. (1990). The African self-consciousness construct and African American students. Journal of College Student Development, 31, 492-499.

Chewning, P. B. (1984). The attitudes of alumni nondonors, donors, and consecutive donors toward Drake University (Doctoral dissertation, Drake University, 1984). Dissertation Abstracts International, 45, Z5055.

Christensen, L. B. (1985). Experimental methodology. Boston: Allyn and Bacon, Inc.

Chronicle of Higher Education. (1999). Chronicle of Higher Education Almanac, 46, 97.

Clark-Carter, D. (1997). Doing quantitative psychological research: From design to report. East Sussex, England: Psychology Press, Ltd.

Clinton, W. J. (1998). Proclamation 7122-National historically Black colleges and universities week, 1998. Weekly Compilation of Presidential Documents, 34, 1801-1802.

Cockriel, I. W. (1983). Don't overlook scholarships as good alumni cultivator. Fund Raising Management, 14, 42-43.

Cortes, C. E. (1976). Understanding you and them. Boulder, CO: ERIC Clearinghouse for Social Studies/Social Science Education. (ERIC Document Reproduction Service No. ED 120 032). 
Council for Aid to Education. (1998). Voluntary support for education. Retrieved from the World Wide Web:

http://www.cae.org/VSE/vse1998/t13.htm

Dahl, R. W. (1981). Early predictors of alumni giving: An empirical study of selected pre-enrollment characteristics and collegiate career experiences in the giving behavior of alumni of a public university (Doctoral dissertation, University of

Kentucky, 1981). Dissertation Abstracts International, 42, Z5055.

Daniel, W. W. (1990). Applied nonparametric statistics.

Boston: PWS-Kent.

Devarics, C. (1999). UNCF urges more federal funding for Black colleges in 2000. Black Issues in Higher Education, 16, 8 .

De Vaus, D. A. (1995). Surveys in social research $\left(4^{\text {th }}\right.$ ed.). St. Leonards, Australia: Allen \& Unwin Pty Ltd.

Digest of Education Statistics 1995. (1995). (U.S. Department of Health, Education, and Welfare, Education Division, National Center for Education Statistics). Washington, DC: U.S. Government Printing Office.

Digest of Education Statistics 1997. (1997). (U.S. Department of Health, Education, and Welfare, Education Division, National Center for Education Statistics). Washington, DC: U.S. Government Printing Office.

Digest of Education Statistics 1998. (1998). (U.S. Department of Health, Education, and Welfare, Education Division, National Center for Education Statistics). Washington, DC: U.S. Government Printing office.

Dillman, D. A. (1978). Mail and telephone surveys: Total design method. New York: John Wiley and Sons.

Drink drive campaign. (1997). Marketing Week, 20, 32-33. 21,17 .

Dunbar, D. (1991). Back-to-school daze. Black Enterprise,

Dupuy-Santiago, A. (1983). Ideological and political implications of education. Unpublished master's thesis, University of Missouri, Columbia.

Enyard, R. K. (1993). A study of the effect of the receipt of financial aid on the rate of giving by alumni of a public midwest university (Doctoral dissertation, University of MissouriColumbia, 1993). Dissertation Abstracts International, 55, 25055.

Evans, A. (1988). The problem of Black financial support for higher education: A critical analysis of five areas of 
tension and potential solutions. Negro Educational Review, 39, $14-24$.

Evans, J. H. (1986). A study of the attitudes of the alumni of historically Black colleges and universities towards financial giving to their alma maters (Doctoral dissertation, Morgan State, 1986). Dissertation Abstracts International, 47, 25055.

Ewers, J. B. (1987). Using Black alumni to recruit Black students. Journal of College Student Personnel, 28, 568-571.

Fact Book on Higher Education, 1989/1990. (1990). New York: American Council on Education: Macmillan.

Fact Book on Higher Education, 1997. (1997). New York: American Council on Education: Macmillan.

Ferguson, G. A. (1981). Statistical analysis in psychology and education. New York: McGraw-Hill Book Company.

Fink, A., \& Kosecoff, J. (1998). How to conduct surveys: A step-by-step guide. London: Sage Publications.

Finlay, K. A., Trafimow, D., \& Jones, D. (1997). Predicting health behaviors from attitudes and subjective norms: Between-subjects and within-subjects analyses. Journal of Applied Social Psychology, 27, 2015-2031.

Fischer, L., \& Thomas, D. R. (1965). Social foundations of educational decisions. Belmont, CA: Wadsworth Publishing Company, Inc.

Fishbein, M. (1967). Attitude and prediction of behavior. In M. Fishbein (Ed.), Readings in attitude theory and measurement (pp.477-492). New York: Wiley.

Fleming, J.(1984). Blacks in college. San Francisco: Jossey-Bass.

Fletcher, M. A. (1997, March 10). Turning support into philanthropy; Schools, charities reach out to growing Black middle class. Washington Post, p. A01.

Flowers, J. V., Miller, T. E., Smith, N., \& Booraem, C. D. (1994). The repeatability of a single-session group to promote safe sex behavior in a male at-risk population. Research on Social Work Practice, 4, 240-247.

Foy, R. (1968). The world of education. New York: Macmillan Company.

Freire, P. (1970). Pedagogy of the oppressed. New York: Herder and Herder. 
Garibaldi, A. (Ed.) (1984). Black colleges and universities: Challenges for the future. New York: Praeger.

Garibaldi, A. (1991). The role of historically Black colleges in fostering resilience. Education in Urban Society, 24, 103-112.

Gergen, D. R. (1998, October 12). A study in Black and White: Why race-sensitive admissions policies work. U.S. News and World Report, 125,84 .

Gose, B. (1996, May 24). Minority students were $24 \%$ of college enrollment in 1994. Chronicle of Higher Education, 47, A32.

Graf, T. (1990, April 10). Black alumni group expands its programs. Maneater, p. 23.

Griffin, O. T. (1991). Strategies for Black student retention: A conceptual review. Western Journal of Black Studies, 15, 235-241.

Gruber, F. C. (1961). Anthropology and education. Philadelphia: University of Pennsylvania Press.

Gurin, P., \& Epps, E. G. (1985). Black consciousness, identity and achievement: A study of students in historically Black colleges. New York: Wiley.

Haddad, F. D. (1986). An analysis of the characteristics of alumni donors and nondonors at Butler University (Doctoral dissertation, West Virginia University, 1986). Dissertation Abstracts International, 47, 25055.

Haggberg, M. (1992). Why donors give. Fund Raising Management, 23, 39+. Retrieved January 13, 2001, from InfoTrac database on the World Wide Web: http://web6.infotrac.galegroup.com/itw/session

Harris, R. L. (1999). The rise of the Black middle class. World and I, 14, 40 .

Harris, T. A. (1994, Summer). Marketing for Black alumns. Journal of College Admissions, 144, 5-11.

Hartsook, R. F. (1998). 77 reasons why people give. Fund Raising Management, 29, 18+. Retrieved January 13, 2001, from InfoTrac database on the World wide Web: http://web6.infotrac.galegroup.com/itw/session 
Harvey, W. B., \& Williams, L. E. (1989). Historically Black colleges, models for increasing minority representation. Education and Urban Society, 21, 328-340.

Haworth, K. (1996, October 4). Continued aid sought for Black colleges. Chronicle of Higher Education, 43, A33. $26-32$.

Hay, T. M. (1990, April). Common ground. Case Currents, 16,

Healy, P. (1996, May 17). A myriad of problems for public Black colleges. Chronicle of Higher Education, 42, A30-A31+.

Hebel, S. (2001, March 16). Colleges anxiously eye plan to repeal the estate tax. Chronicle of Higher Education, 47, A23.

Hemsworth, P. H., Coleman, G. J., \& Barnett, J. L. (1994). Improving the attitude and behaviour of stockpersons towards pigs and the consequences on the behaviour and reproductive performance of commercial pigs. Applied Animal Behaviour Science, 39, 349-362.

House, M. L. (1987). Annual fund raising in public higher education: The development and validation of a prediction equation (Doctoral dissertation, University of Florida, 1987). Dissertation Abstracts International, 49, Z5055.

Hughes, M. S. (1987). Black students' participation in higher education. Journal of College Student Personnel, 9, 291295.

Jaccard, J., Helbig, D. W., Wan, C. K., Gutman, M. A., \& Kritz-Silverstein, D.C. (1990). Individual differences in attitude-behavior consistency: The prediction of contraceptive behavior. Journal of Applied Social Psychology, 20, 575-617.

Jenifer, F. G. (1991, October 16). The supreme court must act to preserve and strengthen historically Black colleges. Chronicle of Higher Education, 38, A60.

Joiner, L. L. (1998). Historically broke colleges and universities. Emerge, 9, 48-53.

Jordan-Cox, C. A. (1987). Psychosocial development of students in traditionally Black institutions. Journal of College Student Personnel, 28, 504-512.

Keller, M. J. C. (1982). An analysis of alumni donor and non-donor characteristics at the University of Montevallo (Doctoral dissertation, University of Alabama, 1982). Dissertation Abstracts International, 44, 25055. 
Kempf, E.J. (1935). Physiology of attitude-emergence of ego-organization. Medical Record, 142, 402-406.

Kessel, F. (1989). Black foundations: Meeting vital needs. Crisis, 96, 14-18.

Korvas, R. J. (1984). The relationship of selected alumni characteristics and attitudes to alumni financial attitudes to alumni financial support at a private college (Doctoral dissertation, University of Missouri-Kansas City, 1984). Dissertation Abstracts International, 45, Z5055.

Kozol, J. (1995). Amazing grace. New York: Crown.

Leatherman, C. (1989, October 25). After years of failing to win alumni gifts, Black colleges step up their efforts: "We're sitting on great potential." Chronicle of Higher Education, 38, A31-A33.

Levey, J. S., \& Greenhall, A. (Eds.) (1983). The concise Columbia encyclopedia. New York: Avon Books.

Lewis, S. A. R. (1992, August 27). Historically Black Colleges enjoy a renaissance. Black Issues in Higher Education, 9, 72-73.

Likert, R. (1932). A technique for the measurement of attitudes. Archives of Psychology, 22, 21.

Littrell, D. P. (1989). Women's college alumnae of an external degree program: An institutional advancement perspective (Doctoral dissertation, University of Missouri-Columbia, 1989). Dissertation Abstracts International, 50, 25055.

Lively, K. (1999, May 7). Grants help Black colleges build fund raising capacity. Chronicle of Higher Education, 45, A45.

Lucas, C. J. (1984). Foundations of education. Englewood Cliffs, NJ: Prentice-Hall, Inc.

Mai, C. F. (1991). A psychiatrist looks at fund raising. Fund Raising Management, 22, 59+. Retrieved January 13, 2001, from InfoTrac database on the World Wide Web: http://web6.infotrac.galegroup.com/itw/session

Mallinckrodt, B., \& Sedlacek, W. E. (1987). Student retention and the use of campus facilities by race. NASPA Journal, 24, 28-32.

Manfredo, M. J., Yuan, S. M., \& McGuire, F. A. (1992). The influence of attitude accessibility on attitude-behavior 
relationships: Implications for recreation research. Journal of Leisure Research, 24, 157-170.

Maoi, G. R., \& Olson, J. M. (1995). Relations between values, attitudes, and behavioral intentions: The moderating role of attitude function. Journal of Experimental Social Psychology, 31, 266-285.

Marcus, D. L. (2000, February 21). Generation x turns out to be generous. U.S. News and World Report, 128, 54 .

Mason, E. J., \& Bramble, W. J. (1977). Research in education. Chicago: Brown and Benchmark, Publishers.

Mays, B. E. (1978). The Black college in higher education. In C. V. Willie \& R. R. Edmonds (Eds.), Black colleges in America (pp. 24-31). New York: Columbia University, Teachers College Press.

McKee, D. F. (1975). An analysis of factors which affect alumni participation and support (Doctoral dissertation, Indiana University, 1975). Dissertation Abstracts International, 36, Z5055.

McLaughlin, R. (1999). African Americans. Zip/Target Marketing, 22, 100-101.

Mercer, J. (1992, September 30). Black alumni groups spurred to action by supreme court's desegregation decision. Chronicle of Higher Education, 39, A25-A26.

Minority total drops again. (1999, August 24). Missourian. Retrieved from World wide Web: http://web.missouri.edu/ jlibrwww/index.html

Miracle, W. D. (1977). Differences between givers and nongivers to the University of Georgia annual fund (Doctoral dissertation, University of Georgia, 1977). Dissertation Abstracts International, 38, 25055.

Morrison, D. M., Gillmore, M. R., Simpson, E. E., Wells, E. A., \& Hoppe, M. J. (1996). Children's decisions about substance use: An application and extension of the theory of reasoned action. Journal of Applied Social Psychology, 26, 1658-1679.

Moskowitz, M. (1994, Fall). The Black medical schools remain the prime training ground for Black doctors. Journal of Blacks in Higher Education, pp. 69-76.

Mosser, J.W. (1993). Predicting alumni/ae gift-giving behavior: A structural equation model approach (Doctoral dissertation, University of Michigan, 1993). Dissertation Abstracts International, 54, 25055. 
Niba, J. N., \& Norman, R. (Eds.) (1989). Recruitment and retention of Black students in higher education. Lanham, MD: University Press of America.

Nicklin, J. L. (1992, May 20). Private giving to colleges rose by 48 in 1990-91. Chronicle of Higher Education, 38, A25A27.

Nicklin, J. L. (1994, February 23). Wooing minority alumni. Chronicle of Higher Education, 40, A29-A30.

Nunnally, J. C. (1967). Psychometric theory. New York: McGraw-Hill Book Company.

Office of Development and Alumni Relations. (1993). Black graduates file printout. Columbia, MO: University of Missouri.

Office of Development and Alumni Relations. (1995). External funding by campus. Columbia, MO: University of Missouri.

Oglesby, R. A. (1991). Age, student involvement, and other characteristics of alumni donors and alumni nondonors of Southwest Baptist University (Doctoral dissertation, University of Missouri-Columbia, 1991). Dissertation Abstracts International, 52, 25055 .

Okunade, A. A. (1996). Graduate school alumni donations to academic funds: Micro-data evidence. American Journal of Economics and Sociology, 55, 213-229.

Okunade, A. A., Wunnava, P. V., \& Walsh, R. (1994). Charitable giving of alumni: Micro-data evidence from a large public university. American Journal of Economics and Sociology, 53, 73-83.

Oliver, M. L., Rodriguez, C. J., \& Mickelson, R. A. (1985). Brown and Black in white: The social adjustment and academic performance of Chicano and Black students in a predominantly White university. Urban Review, 17, 3-23.

Olson, J., and Olson, V. (1988). The University of Missouri: An illustrated history. Columbia, MO: University of Missouri Press.

Orlans, H. (1997). Alumnae gifts. Change, 29, 6.

Parelius, R. J., \& Parelius, P. (1987). The sociology of education. Englewood Cliff, NJ: Prentice-Hall, Inc.

Parsons, P., \& Wethington, D. (1996). Fund-raising appeals to alumni: Two experiments. Journalism and Mass Communication Educator, 51, 44-50. 
Payne, N. J. (1988). The role of Black colleges in an expanding economy. Educational Record, 68, 104-106.

Pearson, W. E. (1996). A study of donor predictability among graduates of a school of education within a "research 1", public university (Doctoral dissertation, University of Virginia 1996). Dissertation Abstracts International, 57, 25055.

Ploski, H. A., \& Williams, J. (Eds.). (1989). The Negro almanac. New York: Gale Research Inc.

Rakestraw, K. (1985). A group apart. Currents, 11, 32-34.

Rawlins, E. B. (1991). Black alumnae of predominantly white colleges: Their effect upon the development of entitlement in Black students (Doctoral dissertation, University of Massachusetts, 1991). Dissertation Abstracts International, 52, Z5055.

Registrar's office. (1995). Undergraduate enrollment by ethnic category 1991-1995. Columbia, MO: University of Missouri.

Retention problems foil Connecticut's soaring Black and Latino enrollment rates. (1999, March, 18). Black Issues in Higher Education, 16, 12.

Reynolds, B. (1992, July 31). Blacks should use their billions to call their own shots. USA Today, p. 9 A.

Roberts, D. H. (1999). Targeting potential donors from the ranks of non-traditional and traditional students at the undergraduate and graduate levels: A comparative analysis for institutional development (Doctoral dissertation, University of Missouri-Columbia, 1989). Dissertation Abstracts International, 61, Z5055.

Robinson, D. M. (1994). A study of selected characteristics of alumni financial support of their alma mater (Doctoral dissertation, Grambling State University, 1994). Dissertation Abstracts International, 57, 25055.

Rosser, A. W. (1997). A stratification analysis of the relationship between and among selected variables related to alumni annual giving to the association of former students (Doctoral dissertation, Texas A\&M University, 1997). Dissertation Abstracts International, 58, 25055.

Salant, P, \& Dillman, D. (1994). How to conduct your own survey. New York: John Wiley and Sons, Inc. 
Sanders, M. B. (1997). Overcoming obstacles: Academic achievement as a response to racism and discrimination. Journal of Negro Education, 66, 83-93.

Schwitzer, A. M., Griffin, O. T., Ancis, J. R., \& Thomas, R. (1999). Social adjustment experiences of African American college students. Journal of Counseling and Development, 77, 189 .

Sedlacek, W. E. (1987). Black students on White campuses: 20 years of research. Journal of College Student Personnel, 28, $484-495$.

Shadoian, H. L. (1989). A study of predictors of alumni philanthropy in public colleges (Doctoral dissertation, University of Connecticut, 1989). Dissertation Abstracts International, 51, Z5055.

Shields, J. J., \& Greer, C. (1974). Foundations of education: Dissenting views. New York: John Wiley and Sons, Inc.

Shoemaker, C. R. (1991). High school graduate follow-up study: Class of 1989 two years after graduation. Phoenix, A2 State Department of Education. (ERIC Document Reproduction Service No. ED 360 366).

Shorb, G. A. (1983). A study of the relationship between perceptions of nursing curriculum and alumni philanthropy (Doctoral dissertation, Saint Louis University, 1983). Dissertation Abstracts International, 44, 25055.

Siegel, S. (1956). Nonparametric statistics for the behavioral sciences. New York: McGraw-Hill Book Company, Inc.

Smith, L. J. (1998). Factors which promote or limit minority alumni support of a predominantly white churchassociated university (Doctoral dissertation, Marquette University, 1998). Dissertation Abstracts International, 59, 25055 .

Smith, L. T. (1987). A predominantly white public university's environment and its relationship to giving from Black and White alumi (Doctoral dissertation, Bowling Green State University, 1987). Dissertation Abstracts International, 48 , Z5055.

Solomon, B. M. (1985). In the company of educated women. New Haven: Yale University Press.

Sowell, T. (1986). Education, assumptions versus history, collected papers. Stanford, CA: Hoover Institution Press. 
Squires, C. (1997). All about donors. Fund Raising Management, 28, 34+. Retrieved January 13, 2001, from InfoTrac database on the world Wide Web:

http://web6.infotrac.galegroup.com/itw/session

Statistical Abstract of the United States: 1997. (1997). Washington, DC: U.S. Government Printing Office.

Statistical Abstract of the United States: 2000. (2000). Washington, DC: U.S. Government Printing Office.

Stikes, C. S. (1984). Black students in higher education. Carbondale, IL: Southern Illinois University Press.

Stockburger, D. W. (1996). Introductory statistics: Concepts, models, and applications. (On-line). Available URL: http://www.psychstat.smsu.edu/introbook/sbk00toc.htm.

Sudarkasa, N. (1990, March 28). All 117 Black colleges and universities require dramatic new levels of philanthropic support. Chronicle of Higher Education, 36, B1.

Swanson, E. B. (1986). The relationship of the characteristics, experiences and attitudes of nursing alumnae to their giving behavior (Doctoral dissertation, University of Iowa, 1986). Dissertation Abstracts International, 47, Z5055.

Taylor, C. A. (1986). Black students at predominantly white college campuses in the 1980s. Journal of College Student Personnel, 27, 196-202.

Taylor, R. (1996, May 16). Rescue for the endangered. Black Issues in Higher Education, 13, 10.

Thayer, V. T., \& Levit, M. (1966). The role of the school in American society. New York: Dodd Mead and Company.

Thomas, G. E., \& Hill, S. (1987). Black institutions in U.S. higher education: Present roles, contributions, future projections. Journal of College Student Personnel, 28, 496-503.

Thomas, G. E., \& McPartland, J. (1981). Have college desegregation policies threatened Black student enrollment and Black colleges? An empirical analysis. Journal of Negro Education, 53, 389-399.

Till, J. M. (1999). Correlates of fund-raising effectiveness in public four-year institutions of higher education (Doctoral dissertation, University of Minnesota, 1999). Dissertation Abstracts International, 60, 25055. 
Townsend, L. (1994). How universities successfully retain and graduate Black students. Journal of Blacks in Higher Education, 4, 85-89.

Tromble, W. W. (1998). Excellence in advancement. Gaithersburg, MD: Aspen Publishers, Inc.

Tuckman, B. W. (1978). Conducting educational research. New York: Harcourt, Brace Jovanovich, Inc.

University of Missouri System. (1999). External funding by campus. Columbia, MO: University of Missouri System.

U.S. Department of Labor, Employment and Training Administration, U.S. Employment Service. (1991). Dictionary of occupational titles (4 $4^{\text {th }}$ ed.). Washington, DC: U.S. Government Printing Office.

Waldrop, J. (1990). Shades of Black: Headlines about Black poverty obscure the large Black middle class and growing number of affluent Blacks. American Demographic, 12, 30-34.

Wallace, D. L, \& Bell, A. (1999). Being Black in a predominantly White university. College English, 61, 307.

Webber, T. L. (1978). Deep like the rivers: Education in the slave quarter community 1831-1865. New York: W.W. Norton and Company, Inc.

Wetta, T. (1990). A study of the characteristics and attitudes which distinguish financial donors from nondonors among baccalaureate graduates of selected Kansas independent colleges (Doctoral dissertation, Boston College, 1990). Dissertation Abstracts International, 52, 25055.

Whiting, A. N. (1988). Black colleges, an alternative strategy for survival. Change, 20, 10-11.

Wilkins, G. C., \& Emanuel-Wallace, R. (1990). Healing old wounds. Case Currents, 16, 38-41.

Wilson, R. (1990). Can Black colleges solve the problem of access for Black students? American Journal of Education, 98, $443-457$.

Wilson, R., \& Justiz, M. J. (1987-1988, Fall-Winter). Minorities in higher education: Confronting a time bomb. Educational Record, 68, 8-14.

Winbush, D. E. (1996). Following the leader: Other institutions search for the secrets of Spelman's success. Black Issues in Higher Education, 13, 19. 
Woodson, C. G. (1968). The education of the Negro prior to 1861. Salem, NH: Ayer Company Publishers, Inc. 


\section{APPENDIX A}

\section{Black Alumni Survey}

Directions: This survey is to determine alumni feelings and attitudes toward Mizzou. Please check the response that best reflects your views on each of the following questions.

SECTION I: LEADERSHIP OF THE CHANCELLOR

* The current chancellor is an effective leader.

* He communicates effectively with all his constituencies, including business leaders, politicians, and alumni.

* His organizational and management skills are effective.

* I would like to see the chancellor continue as the leader of Mizzou.

* My impression of the chancellor has significant influence on my financial giving.

Note: These Likert-type items have available responses of: Strongly Agree, Agree, Disagree, and Strongly Disagree. The response lines are deleted here in the interests of brevity.

SECTION II: PUBLIC IMAGE OF MIZZOU

* Mizzou is nationally respected for the quality of its programs and services. 
* Mizzou attracts highly academic students.

* Mizzou's fiscal management is satisfactory.

* The quality of education at Mizzou has always been competitive.

* Media coverage of programs and events at Mizzou is positive.

* The perceived public image of Mizzou has a significant influence on my financial giving.

SECTION III: FREQUENCY AND CLARITY OF MIZZOU'S CORRESPONDENCE ADDRESSED TO ALUMNI

* I am kept sufficiently informed about Mizzou's programs and services.

* I receive regular memoranda concerning the fiscal needs of Mizzou.

* Written communication from Mizzou is clear and effective.

* The frequency and clarity of the correspondence from Mizzou has significant influence on my financial giving.

\section{SECTION IV: THE ALUMNI ASSOCIATION}

* The Alumni Association uses various means (newsletters, phonathons, meetings) to keep alumni informed about current developments relative to alumni affairs.

* The leaders of the Alumni Association are effective managers and organizers.

* The quality of the Alumni Association at Mizzou has significant influence on my financial giving. 
SECTION V: EDUCATIONAL EXPERIENCES

* My course work was interesting and challenging.

* The campus experiences included a variety of cultural and social activities which enhanced my educational experiences.

* My instructors/professors demonstrated genuine interest in my education.

* My experiences at Mizzou were positive.

* The education adequately prepared me for the world of work.

* The quality of my educational experiences has a significant influence on my annual giving.

SECTION VI: ANNUAL GIVING

* The chancellor needs to be more actively involved in the solicitation of financial support from alumni.

* The purpose for fund raising projects should be more clearly defined and communicated to alumni.

* Mizzou needs a better marketing program to promote its educational strengths and services.

* My financial contributions will improve significantly the curricula and non-curricula programs at Mizzou.

SECTION VII: YOU AND YOUR FAMILY (Confidential information for statistical analysis of previous data.)
Are you:
MALE
FEMALE 


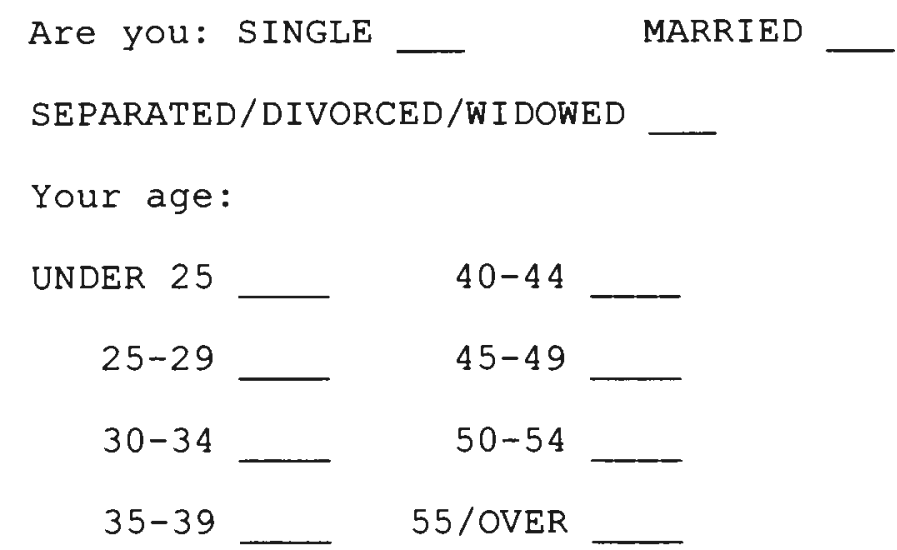

Check the highest level of education you have received. COLLEGE GRADUATE _ _ POST GRADUATE -

Check your total family income before taxes for 1995. UNDER $\$ 15,000 \_\$ 25,000-34,999$

$\$ 15,000-19,999 \_\$ 35,000-49,999$

$\$ 20,000-24,999 \ldots \$ 50,000 /$ OVER 
APPENDIX B

\section{Communications with Respondents}

\section{Initial Contact Letter}

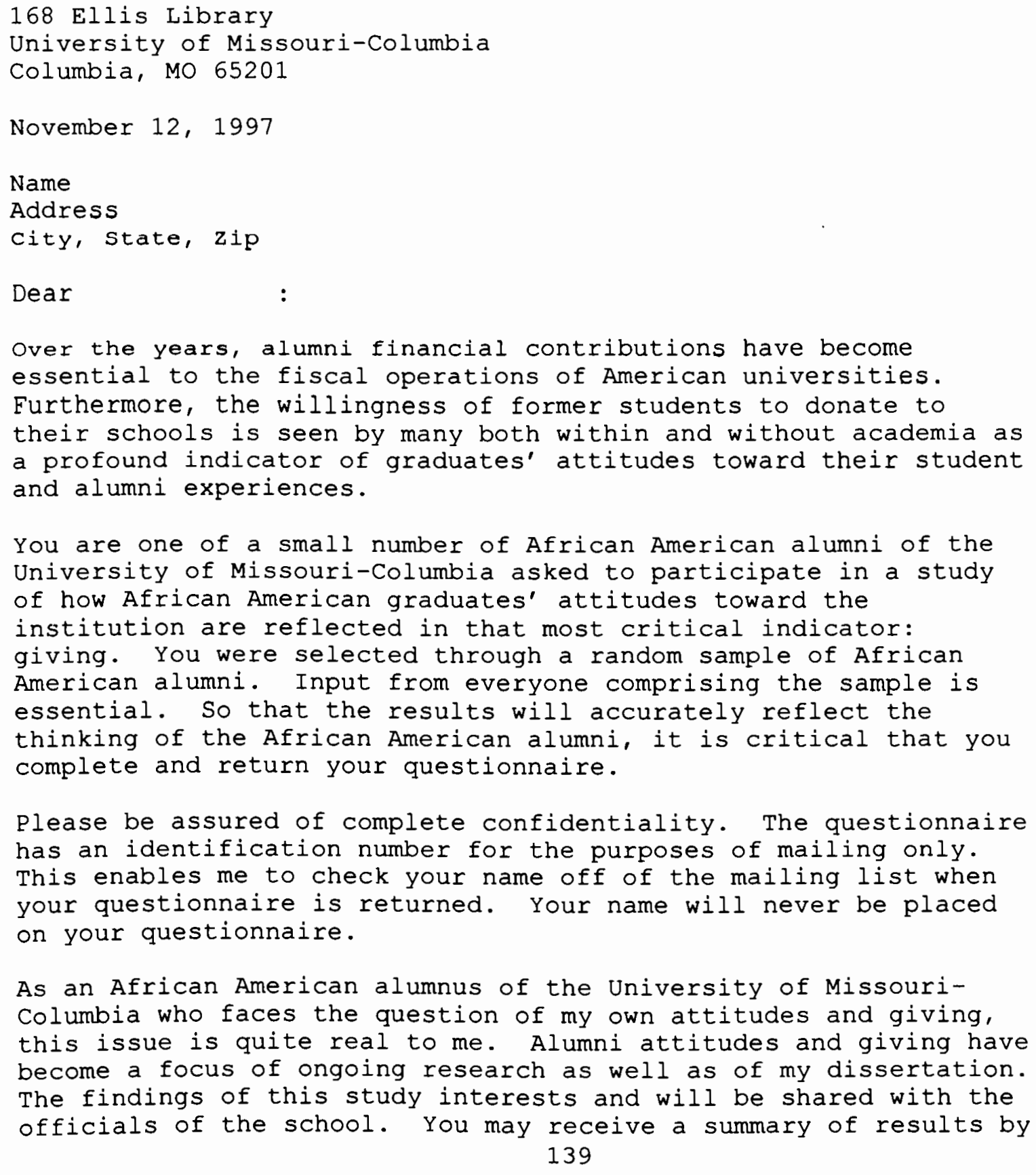

Please be assured of complete confidentiality. The questionnaire has an identification number for the purposes of mailing only. This enables me to check your name off of the mailing list when your questionnaire is returned. Your name will never be placed on your questionnaire.

As an African American alumnus of the University of MissouriColumbia who faces the question of my own attitudes and giving, this issue is quite real to me. Alumni attitudes and giving have become a focus of ongoing research as well as of my dissertation. The findings of this study interests and will be shared with the officials of the school. You may receive a summary of results by 139 
writing "copy of results requested" on the back of the return envelope, and printing your name and address below it. Please do not place this information on the questionnaire itself.

I would be happy to answer any questions that you may have. Please write or call. My telephone number is (573)882-3326; my e-mail address is elspaulaeshowme.missouri.edu; and my fax is [573] $882=8044$.

Thank you for your help.

Yours truly,

Paula Roper

Enclosures

\section{First Eollow-up Letter}

November 25,1997

Last week a questionnaire designed to determine your attitudes toward your student and alumni experiences at the University of Missouri-Columbia was mailed to you. Your name was drawn in a random sample of African American alumni of the school.

If you have already completed and returned the instrument, please accept my sincere thanks. If you haven't, please do so today. Because the questionnaire was sent to only a small, but representative sample of the African American alumni of Mizzou, it is very important that yours be included in the study if the results are to accurately represent the opinions of African American alumni.

If, by chance, you did not receive the questionnaire, or it was misplaced, please call me right now, collect (573/882-3326)-if I'm not at my desk leave a voice mail message-and $I$ will get you another one in the mail immediately.

Yours truly,

Paula Roper 
168 Ellis Library

University of Missouri-Columbia

Columbia, MO 65201

December 23, 1997

Name

Address

City, State, zip

Dear

Several weeks ago, I wrote asking you as an alumni of the University of Missouri-Columbia what your attitudes were toward that institution and whether those attitudes were reflected in your willingness to donate to the school.

This study was undertaken not only for my dissertation but also as ongoing research into a critical issue facing universities in light of the demographic changes predicted to transform the society in the next few decades.

I am writing to you again because of the importance of each questionnaire to the usefulness of this study. Your name was drawn through a scientific sampling process in which every African American alumnus of the university had an equal chance of being chosen. This means that only approximately one alumnus in seven is being asked to complete this questionnaire. In order for the results of this study to be truly representative of the opinions of all African American alumni, it is essential that each person in the sample return his or her questionnaire.

In the event that your questionnaire has been misplaced, a replacement is enclosed.

Your cooperation is appreciated.

Yours truly,

Paula Roper

P.S. Several people have written asking when the results will be available. I hope to have them in a few months. 


\section{Third Follow-up Letter}

168 Ellis Library

University of Missouri-Columbia

Columbia, MO 65201

February 21, 1988

Name

Address

City, State, Zip

Dear :

I am writing to you about whether your attitudes toward the University of Missouri-Columbia are reflected in your giving. I have not yet received your completed questionnaire.

While the large number of questionnaires returned is encouraging, being able to describe accurately how African American alumni feel about these critical issues depends on you and others who have not responded. Experience has shown that those who have not yet sent in their questionnaires may have very different views from those who have.

Studies of alumni giving are rare; those of African American alumni giving are even rarer. Certainly for African American alumni of the University of Missouri-Columbia this is a unique opportunity to express truly crucial opinions that will be shared with the decision-makers of the institution. The usefulness of the results of this study depends on how accurately it reflects the attitudes of African American alumni.

It is for these reasons this is being sent certified mail to insure delivery. In case our other correspondence did not reach you, a replacement questionnaire accompanies this letter. I ask that you complete and return it as soon as possible.

If you would like to have them, I'll send you a copy of the results. Please put your name, address, and "copy of the results" on the back of the return envelope. I expect to send them within a month or so.

I will appreciate your contribution to this study.

Yours truly,

Paula Roper

Enclosures 


\section{APPENDIX C}

\section{Letter of Permission}

(Letter from Dr. Evans authorizing the use of her instrument.)

CITY OF BALTIMORE
KURT L. SCHMOKE. Miagor

HaY 20, 1993

HE. Paula LaJean Roper

Social Sciences Librarien

Untversity of Misouri-Columbla

B111: Library

Room 168, South

Columbla, Hesouri 65201-5149

Doar Hs. Roper

I hereby grant you permisston to use my research instrument and protocole in the structuring of your study on alumi attitudes. If I can aselat in any other way, please do not hesitate to call me at (410) 396-8705.

Best w1ahoe!

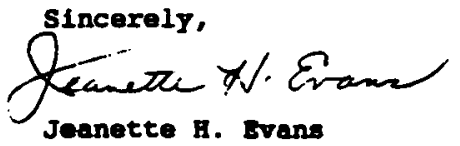

/ja

Q3 Prnied un recycled paper with enveromencally inendly wy besed int 
VITA

Paula Roper, born in St. Louis, Missouri, attended public schools in that city until the third grade when she transferred to the parochial system. After high school, she went on to attend a community college in her home city and eventually the University of Missouri-St. Louis where she earned a B.S. in Education with a minor in history.

Paula worked for a number of years as a teacher and then for several federally funded projects before returning to school at the University of Missouri-Columbia, where she earned a M.A. in Library Science. Later, she pursued a Ph.D. in Educational Leadership and Policy Analysis with an emphasis in Higher Education. Educational History was her inside support area and Information Science, her outside support area.

Paula was awarded a fellowship while pursuing her master's degree and served as a teaching assistant for the library skills course taught on the campus. She is a reference librarian at Ellis Library, the main library on the campus of the University of Missouri-Columbia. Education and Black Studies are her subject specialties in librarianship. 
$\underset{\text { NO } 35301-83}{594 \mathrm{IMC}-\mathrm{TH}} 2455$ 


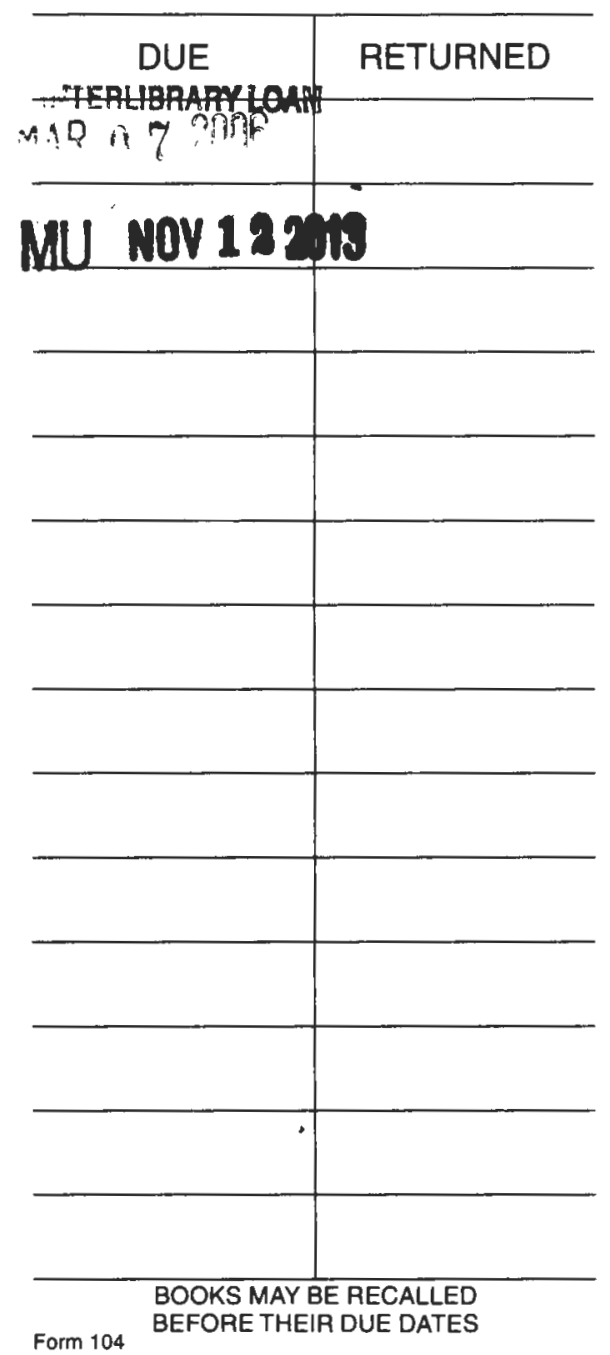


Urwersity of Missour - Columbia

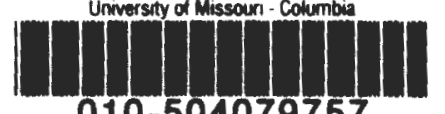

010-504079757 



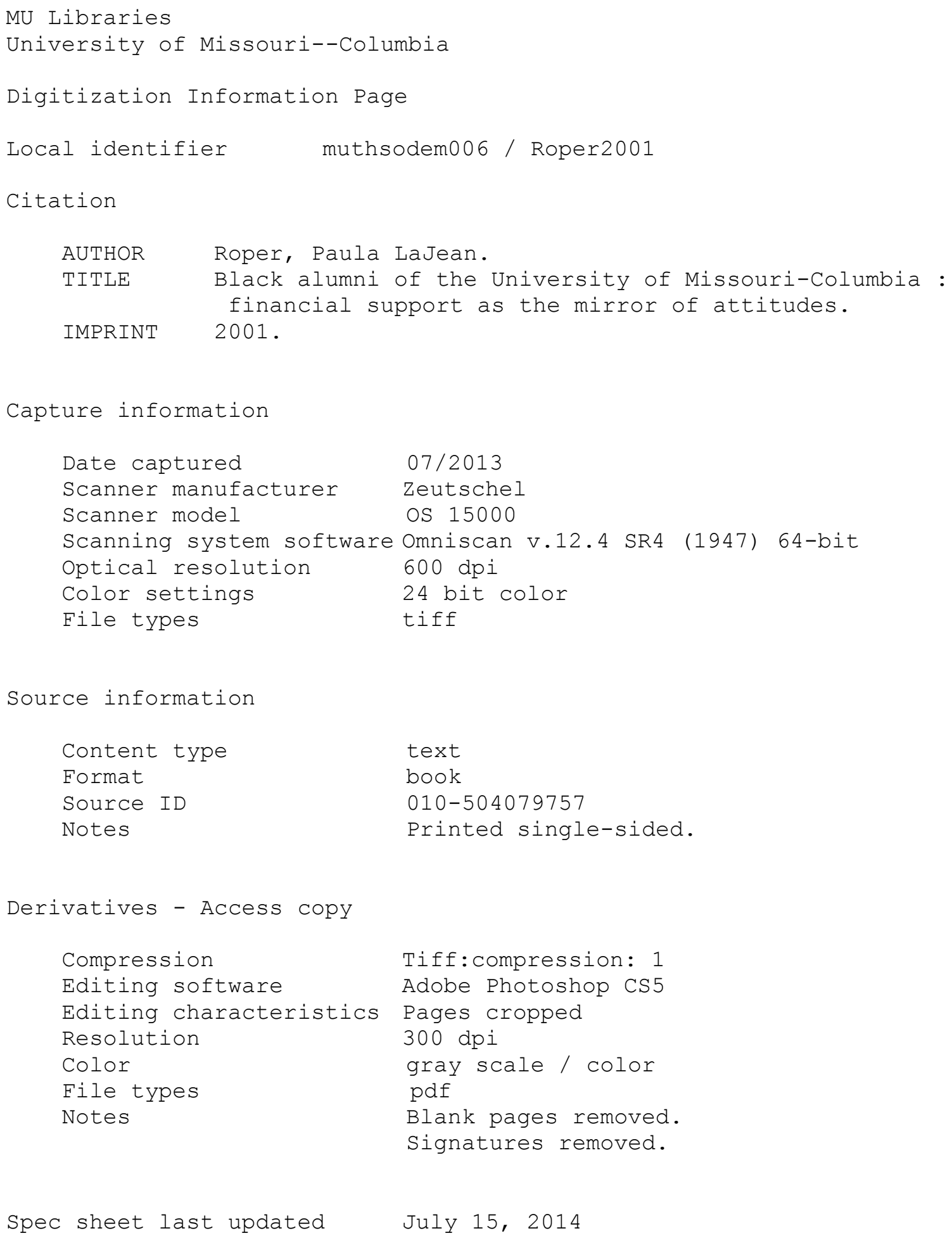

Spec sheet last updated July 15, 2014 